Prepared for PM-CBRN IPP

Under U.S. Department of Energy contract DE-AC05-76RL03180

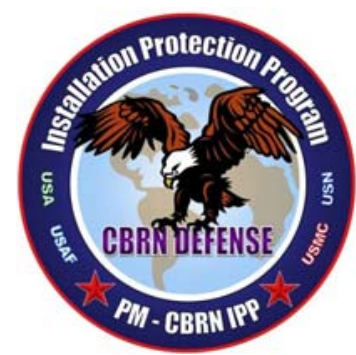

\title{
Symetrica Measurements at PNNL
}

\section{Technical Support for DoD Radiological Protection Issues}

Revision 0

PIET-48581-TM-037
RT Kouzes
RL Redding
EK Mace
DC Stromswold

January 2009 


\title{
DISCLAIMER
}

This report was prepared as an account of work sponsored by an agency of the United States Government. Neither the United States Government nor any agency thereof, nor Battelle Memorial Institute, nor any of their employees, makes any warranty, express or implied, or assumes any legal liability or responsibility for the accuracy, completeness, or usefulness of any information, apparatus, product, or process disclosed, or represents that its use would not infringe privately owned rights. Reference herein to any specific commercial product, process, or service by trade name, trademark, manufacturer, or otherwise does not necessarily constitute or imply its endorsement, recommendation, or favoring by the United States Government or any agency thereof, or Battelle Memorial Institute. The views and opinions of authors expressed herein do not necessarily state or reflect those of the United States Government or any agency thereof.

\author{
PACIFIC NORTHWEST NATIONAL LABORATORY \\ operated by \\ BATTELLE \\ for the \\ UNITED STATES DEPARTMENT OF ENERGY \\ under Contract DE-AC05-76RL01830
}

Printed in the United States of America
Available to DOE and DOE contractors from the Office of Scientific and Technical Information,
P.O. Box 62, Oak Ridge, TN 37831-0062;
ph: (865) 576-8401
fax: $(865)$ 576-5728
email: reports@adonis.osti.gov

\begin{abstract}
Available to the public from the National Technical Information Service, U.S. Department of Commerce, 5285 Port Royal Rd., Springfield, VA 22161 ph: (800) 553-6847 fax: $(703) 605-6900$ email: orders@ntis.fedworld.gov online ordering: http://www.ntis.gov/ordering.htm
\end{abstract}

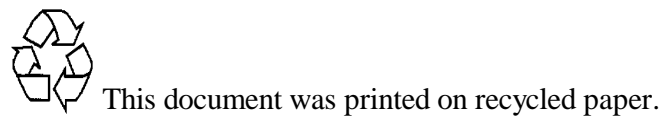




\section{Symetrica Measurements at PNNL}

Technical Support for DoD Radiological Protection Issues

Revision 0

PIET-48581-TM-037

$\begin{array}{ll}\text { RT Kouzes } & \text { RL Redding } \\ \text { EK Mace } & \text { DC Stromswold }\end{array}$

January 2009

Prepared for PM-CBRN IPP

Under U.S. Department of Energy Contract DE-AC05-76RL01830

Pacific Northwest National Laboratory

Richland, Washington 99352 



\section{Executive Summary}

Symetrica is a small company based in Southampton, England, that has developed an algorithm for processing gamma ray spectra obtained from a variety of scintillation detectors. Their analysis method applied to $\mathrm{NaI}(\mathrm{Tl}), \mathrm{BGO}$, and $\mathrm{LaBr}$ spectra results in deconvoluted spectra with the "resolution" improved by about a factor of three to four. This method has also been applied by Symetrica to plastic scintillator with the result that the deconvolved spectra have full energy peaks. If this method is valid and operationally viable, it could lead to a significantly improved plastic scintillator based radiation portal monitor system.

Symetrica's method of spectral analysis was demonstrated at Pacific Northwest National Laboratory (PNNL) using NaI(Tl) and plastic scintillators. Unfortunately, the plastic scintillator was damaged in shipment from England, and no useful data were obtained. However, NaI(Tl) detectors were tested using various industrial sources, special nuclear material (SNM), and naturally occurring radioactive material (NORM).

Symetrica's analysis generally provided detection and correct identification of the sources (typically a few $\mu \mathrm{Ci}$ for the industrial sources and $100 \mathrm{~g}$ for SNM, located at one to two meters) in measurement intervals lasting 10 seconds.

The data were also analyzed at PNNL using GADRAS, a gamma ray template-based, spectral analysis software toolset. GADRAS correctly classified most of the sources and identified their main isotopes. It also categorized them by SNM probability and Threat Level. There were several instances where GADRAS identifies isotopes that were not present during data collection but acknowledged it as a weak identification (ID) with either fair or low confidence. The only Bad ID was on the NORM sample of lanthanum carbonate but it was still classified as a very low probability SNM.

ScintiVision, a gamma-ray spectral analysis program from ORTEC, was also used at PNNL to analyze the data. ScintiVision was not as easy to use for analysis as GADRAS and the results from it were generally unsatisfactory, with many incorrect nuclides being identified.

Although it was not possible to test the Symetrica algorithm with PVT scintillator because of its damage in shipment, it would be highly desirable to do this testing in the future. The good performance of Symetrica's algorithm, and GADRAS, with $\mathrm{NaI}(\mathrm{Tl})$ suggests that significant improvements in spectral processing might also be obtained for PVT detectors. In particular, reduction in nuisance alarms for portal monitors might be accomplished, in comparison to what is traditionally observed for PVT detectors. 



\section{Contents}

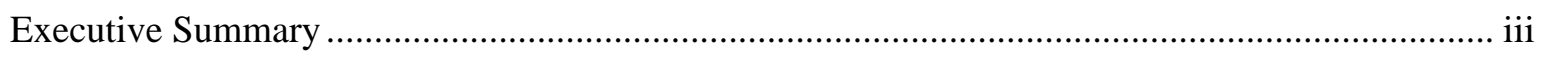

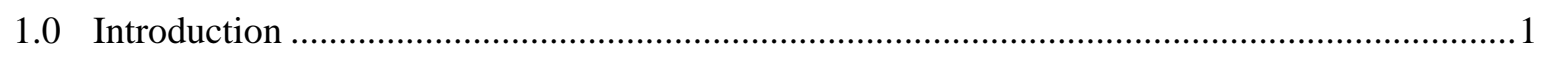

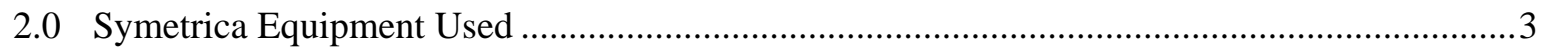

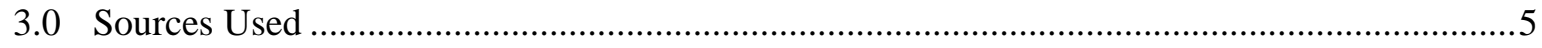

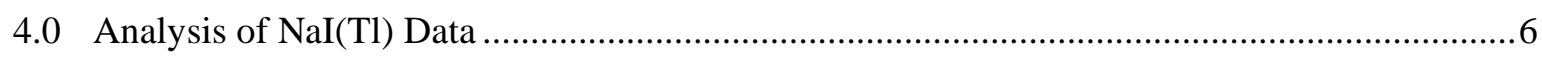

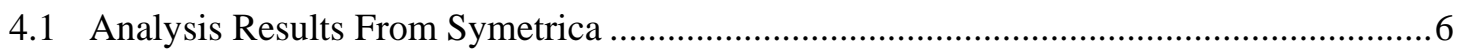

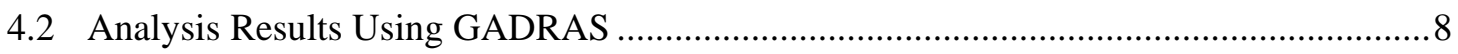

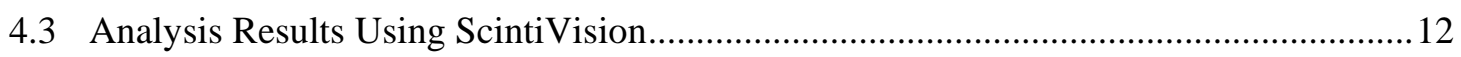

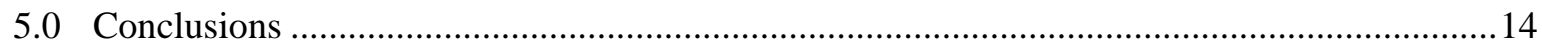

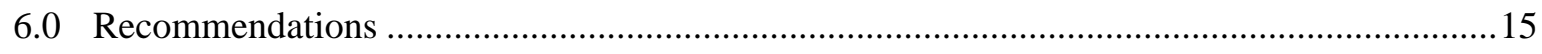

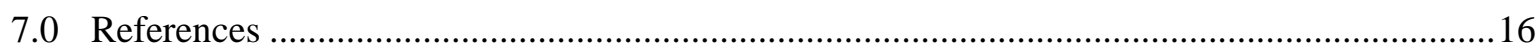

Appendix A Measurements Performed .................................................................................

Appendix B Summary of Measurements Made at PNNL ............................................................. B.1

Appendix C Symetrica Results (by M. Dallimore et al.) ........................................................... C.1



Appendix E Library of Isotopes Used for ScintiVision Analysis ............................................... E.1

Appendix F Complete ScintiVision Results .......................................................................... 1 


\section{Figures}

Figure 1. Example of PVT Spectrum of ${ }^{60} \mathrm{Co}$ and Deconvoluted Spectrum

[Ramsden and Dallimore 2008].... 1

Figure 2. a) A Raw ${ }^{226}$ Ra Energy Spectrum Recorded with a 2"x2" NaI(Tl) Detector and

b) the Deconvoluted Spectrum with the Peaks Labeled [Crossingham et al. 2003] ...................2

Figure 3. Symetrica Systems Against Far Wall: NaI(Tl) system (left) and PVT System (right).......3

Figure 4. Response of Symetrica PVT System to a ${ }^{22}$ Na source in England and PNNL ..................4

Figure 5. Screen Capture of Detector Response Parameters........................................................8

Figure 6. ${ }^{60}$ Co Spectrum Analyzed in GADRAS ......................................................................

Figure 7. GADRAS Example of Misidentification but Correct Classification ................................11

Figure 8. GADRAS Example of Correct Identification and Correct Classification ........................11

Figure 9. ${ }^{60}$ Co spectrum Analyzed in ScintiVision .................................................................. 13

\section{Tables}

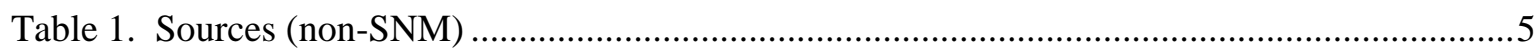

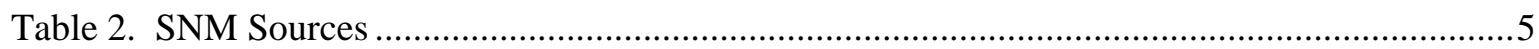

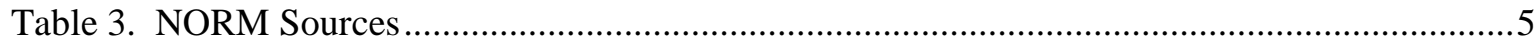

Table 4. Summary of Shielded-Source Identification From Symetrica .......................................... 7

Table 5. Summary of Source Identifications From Symetrica.....................................................

Table 6. Summary of Source Identification in GADRAS.......................................................... 10

Table 7. Summary of Shielded-Source Identification using GADRAS ........................................ 10

Table 8. Summary of Source Identification in ScintiVision ........................................................ 12 


\subsection{Introduction}

Scintillation detectors for gamma rays play a central role for homeland security applications for the detection of illicit radioactive materials. Polyvinyl toluene (PVT) plastic scintillator is the most commonly used detector material for radiation portal monitor (RPM) systems, while $\mathrm{NaI}(\mathrm{Tl})$ is used in spectroscopic portal monitor (SPM) systems and handheld devices. Some handheld detectors using $\mathrm{LaBr}$, and CZT detectors are in development. While PVT-based systems provide the required capability to alarm on the presence of gamma radiation, they cannot in general distinguish all threat materials from some naturally occurring radioactive material (NORM) that can produce an operational burden for homeland security applications. Identification of the radionuclides responsible for producing an alarm in a RPM system is thus desired, and has driven the need for SPM systems in some applications. Systems based upon $\mathrm{NaI}(\mathrm{Tl})$ detectors are much more costly than those based on PVT, so if the spectroscopic capability of PVT could be improved it may be possible to use the more cost effective PVT-based systems for radionuclide identification, or at least for NORM rejection.

Symetrica is a small company based in Southampton, England, that has developed an algorithm for processing gamma ray spectra obtained from a variety of scintillation detectors [Burt 2008; Foster 2008; Meng and Ramsden 2000; Ramsden and Dallimore 2008; Crossingham et al. 2003; Dallimore et al. 2003]. Their analysis method applied to $\mathrm{NaI}(\mathrm{Tl}), \mathrm{BGO}$, and $\mathrm{LaBr}$ spectra results in deconvoluted spectra with the "resolution" improved by about a factor of three to four. This method has been applied to PVT with the result that full energy peaks are produced, as seen in Figure 1 [Ramsden and Dallimore 2008]. A $\mathrm{NaI}(\mathrm{Tl})$ analysis example is shown in Figure 2. If this method is valid and operationally viable, it could lead to an improved PVT-based RPM system.

In order to test Symetrica's algorithm, equipment was brought to PNNL for measurements with a variety of sources, including special nuclear material (SNM). This provided Symetrica with data on SNM that was previously unavailable. Dr. Matthew Dallimore and Thomas Meeks of Symetrica came to PNNL November 3-5, 2008, to make these measurements, working with the authors of this report.

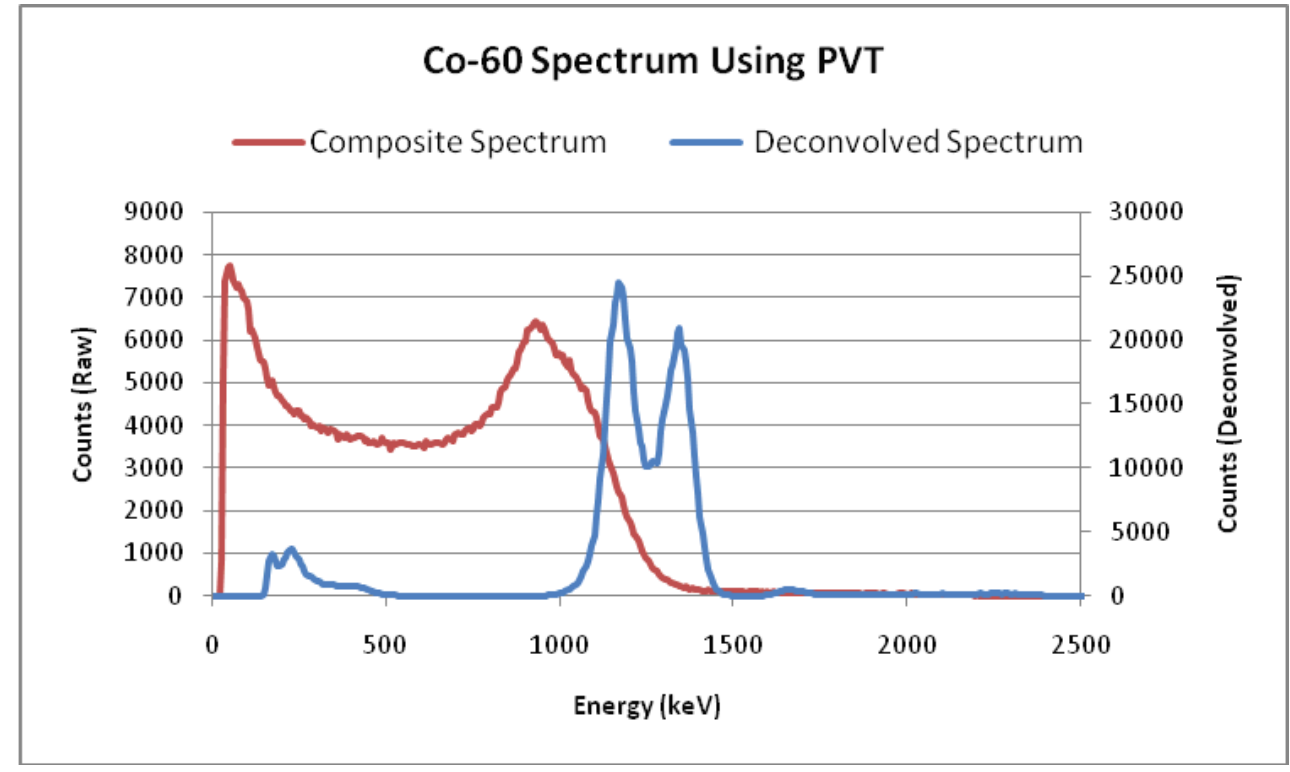

Figure 1. Example of PVT Spectrum of ${ }^{60} \mathrm{Co}$ and Deconvoluted Spectrum [Ramsden and Dallimore 2008] 


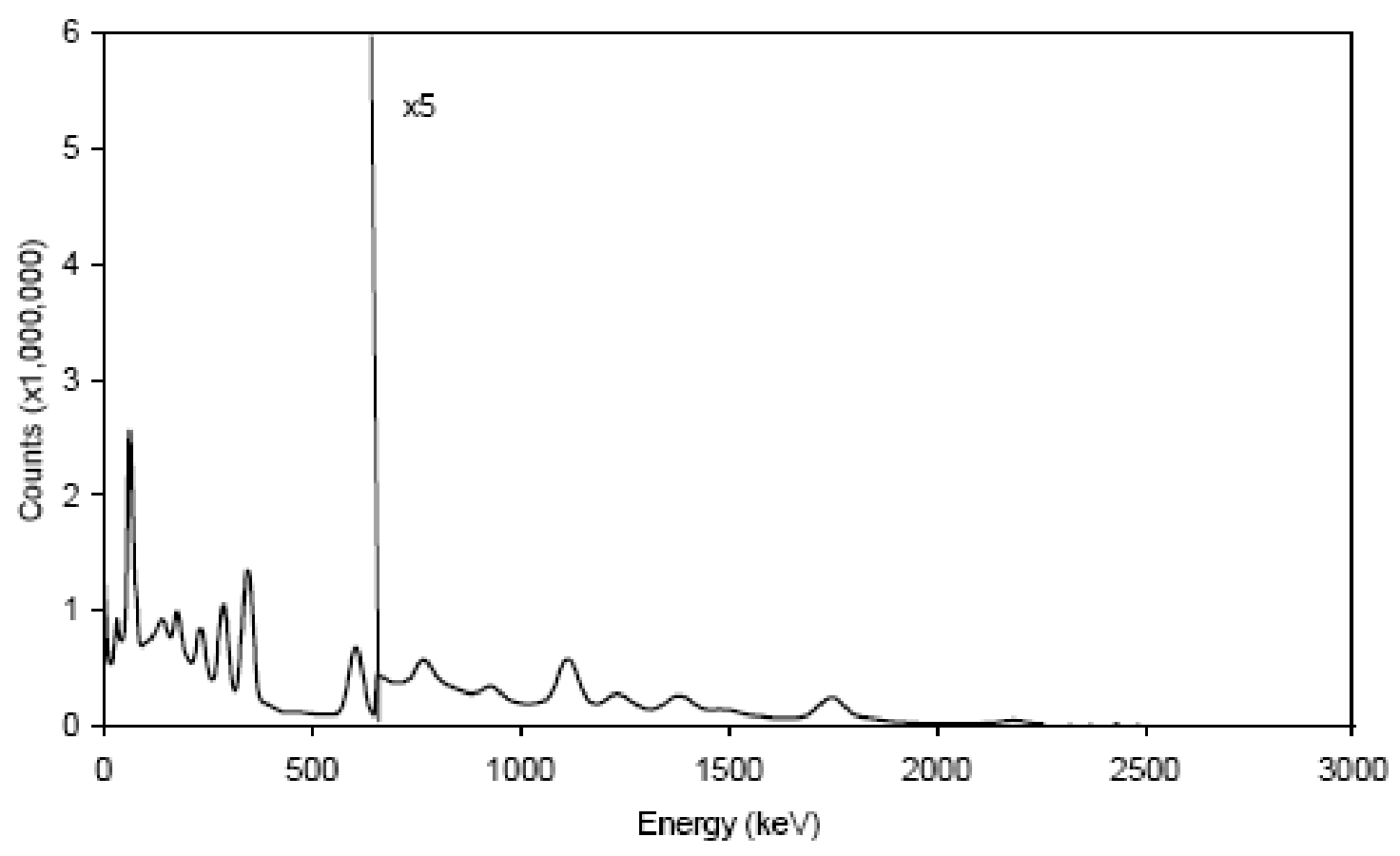

a)

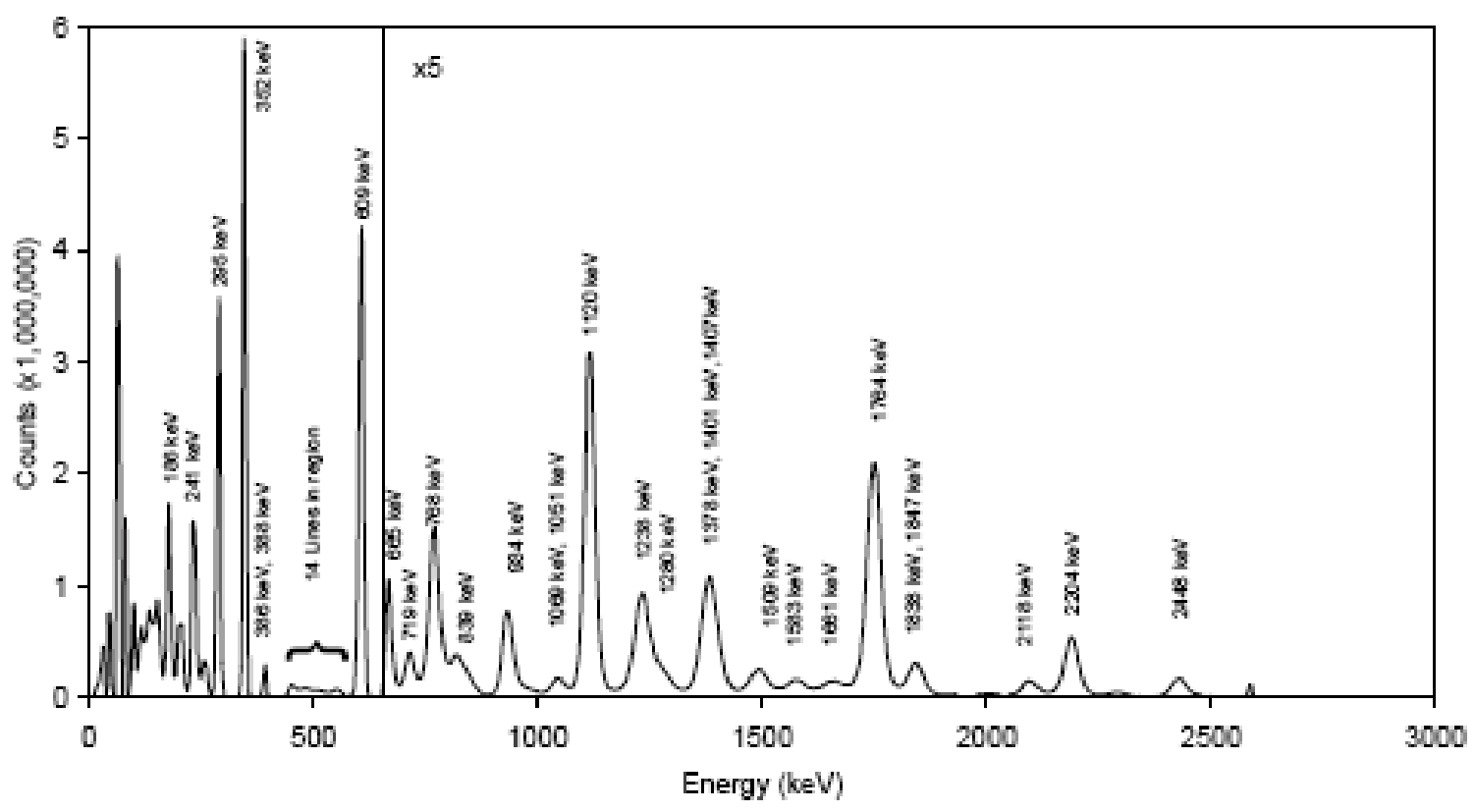

b)

Figure 2. a) A Raw ${ }^{226}$ Ra Energy Spectrum Recorded with a 2"x2" NaI(Tl) Detector and b) the Deconvoluted Spectrum with the Peaks Labeled [Crossingham et al. 2003] 


\subsection{Symetrica Equipment Used}

Symetrica brought two systems (Figure 3) to PNNL for testing: a dual 2"x4"x16" NaI(Tl) system, and a PVT based system $(\sim 1 \mathrm{~m}$ x $0.25 \mathrm{~m})$.

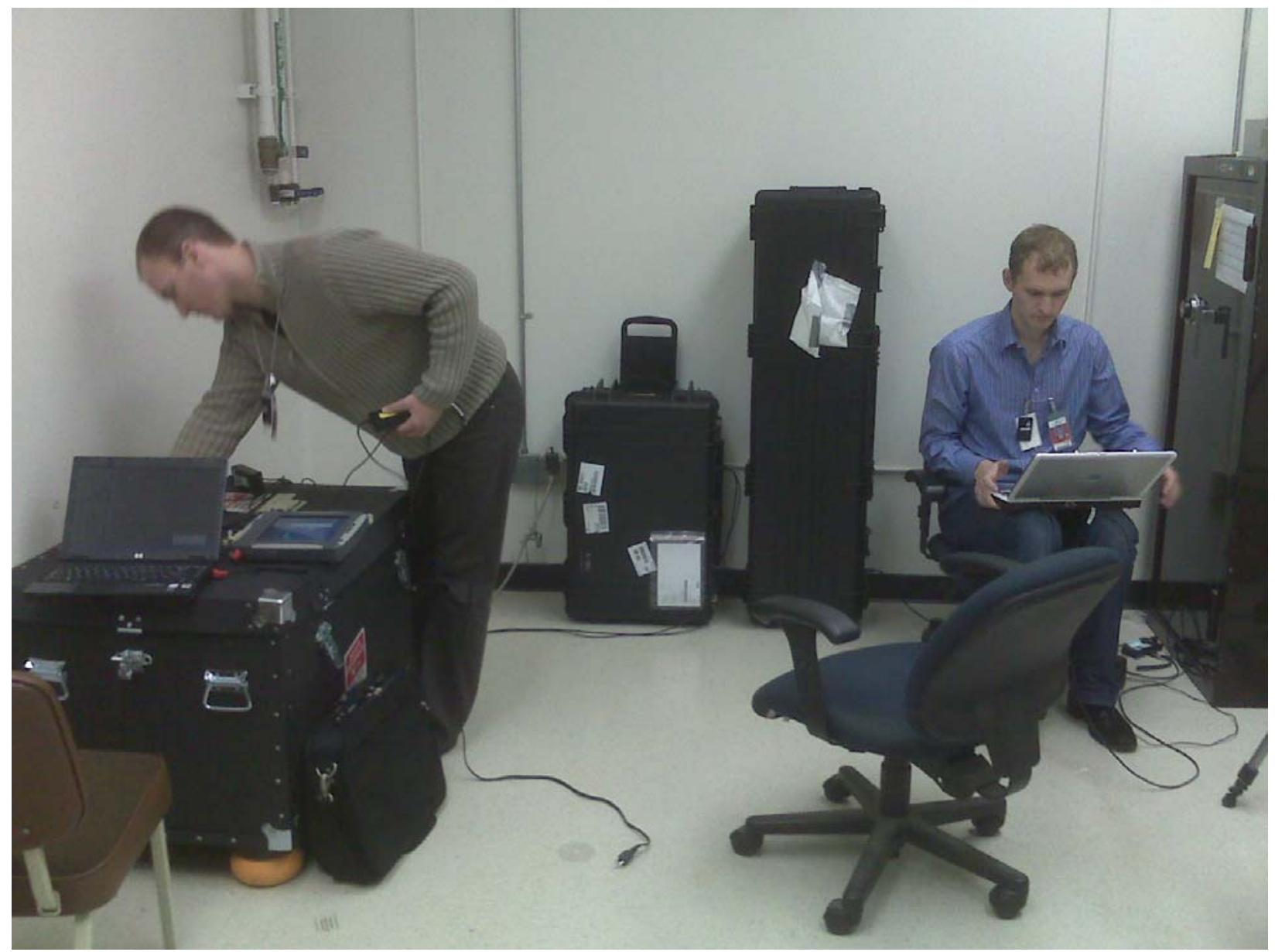

Figure 3. Symetrica Systems Against Far Wall: NaI(Tl) system (left) and PVT System (right)

Both of the Symetrica systems arrived broken from mishandling in shipment. The two NaI(Tl) detectors were swapped out for PNNL-owned detectors. The NaI(Tl) system was then ready for use (although at poorer energy resolution than achieved by the original detectors)..

The phototubes were removed and remounted on the PVT system. But much poorer resolution was still obtained at PNNL. PVT data were taken for some sources. Figure 4 shows ${ }^{22} \mathrm{Na}$ source spectra taken with their PVT system in Chillworth, England, and at PNNL. The PVT system remained too degraded in performance, and did not have sufficient resolution to be used for the Symetrica algorithm. Symetrica's more robust PVT assembly is being tested at AWE in England, and this assembly, or one like it, should be used for any future measurements. 


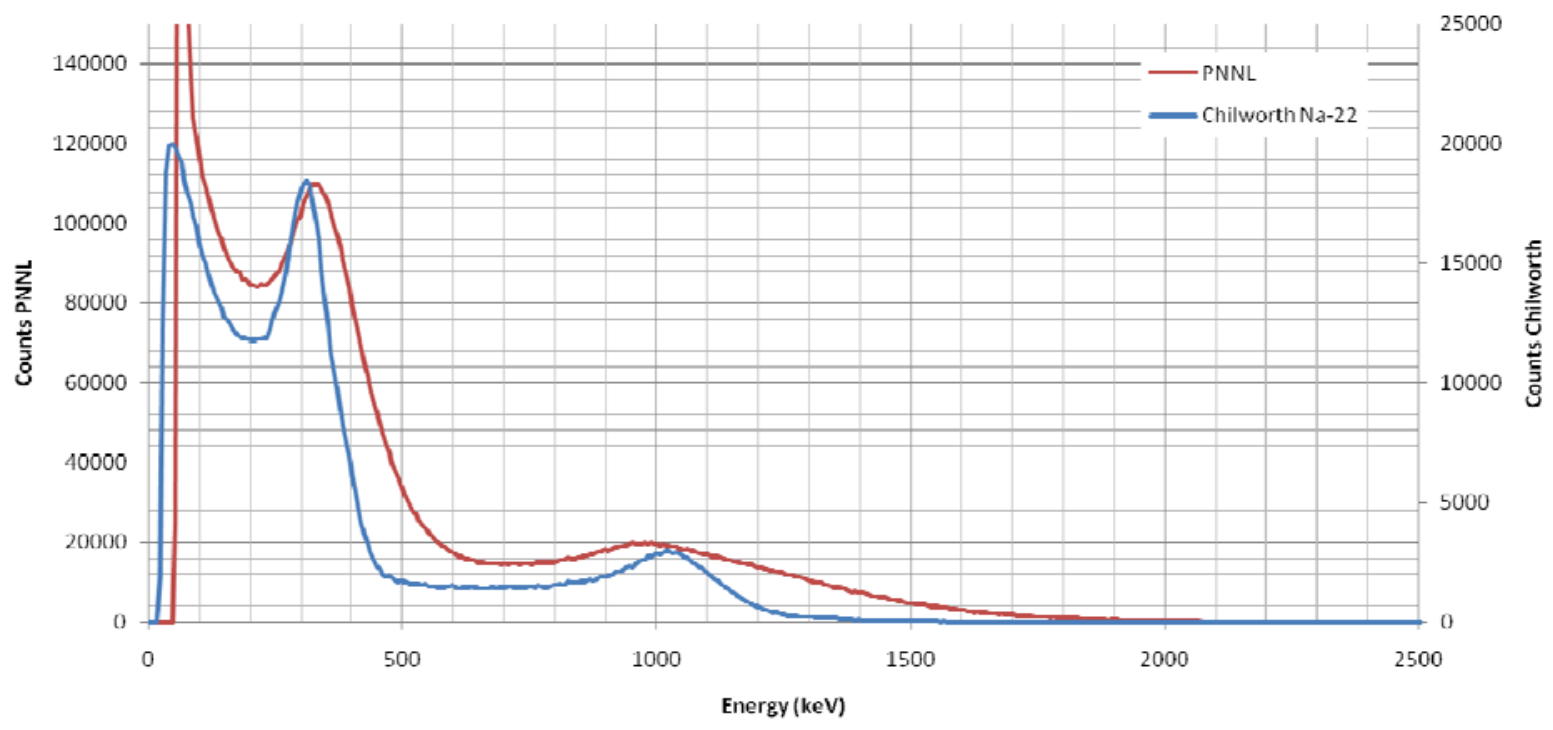

Figure 4. Response of Symetrica PVT System to a ${ }^{22}$ Na source in England and PNNL 


\subsection{Sources Used}

A variety of SNM, industrial and NORM sources were used during these measurements. Table 1 lists the sealed industrial sources used, Table 2 lists the SNM sources used, and Table 3 lists the NORM sources used.

Table 1. Sources (non-SNM)

\begin{tabular}{lllll}
\hline \multicolumn{1}{c}{ Isotope ID } & \multicolumn{1}{c}{ Source ID } & \multicolumn{1}{c}{ Half-life } & \multicolumn{1}{c}{ Assay Date } & Current Activity \\
\hline Ba-133 & $56595-125$ & $10.52 \mathrm{y}$ & $11.0 \mathrm{uCi}-$ Aug1, 2003 & $7.77 \mathrm{uCi}$ \\
Co-57 & $58705-49$ & $271.8 \mathrm{~d}$ & $19.9 \mathrm{uCi}-\mathrm{Jun} 15,2006$ & $2.13 \mathrm{uCi}$ \\
Co-60 & $58705-79$ & $5.27 \mathrm{y}$ & $9.870 \mathrm{uCi}-\mathrm{Jan} 1,2007$ & $7.74 \mathrm{uCi}$ \\
Cs-137 & $58705-84$ & $30.2 \mathrm{y}$ & $9.609 \mathrm{uCi}-$ Feb1, 2007 & $9.23 \mathrm{uCi}$ \\
Eu-152 & $4491-125-0-1$ & $13.33 \mathrm{y}$ & $265.5 \mathrm{uCi}-$ Oct13, 1982 & $69 \mathrm{uCi}$ \\
Na-22 & $56595-151 \mathrm{G}$ & $2.6 \mathrm{y}$ & $10.4 \mathrm{uCi}-$ Oct15, 2004 & $3.523 \mathrm{uCi}$ \\
\hline
\end{tabular}

Table 2. SNM Sources

\begin{tabular}{|c|c|c|c|c|}
\hline Source & Source ID & Amount & & \\
\hline WGPu & 19B14B & $98 \mathrm{~g}$ & $94.4 \%$ Pu239, 5.6\% Pu240 & $\begin{array}{l}4.5 \mathrm{~cm} \text { diameter double- } \\
\text { encapsulated stainless steel } \\
\text { cylinder }\end{array}$ \\
\hline $\mathrm{RGPu}$ & 19B14C & $98 \mathrm{~g}$ & $80.3 \%$ Pu239, $19.1 \%$ Pu240 & $\begin{array}{l}4.5 \mathrm{~cm} \text { diameter double- } \\
\text { encapsulated stainless steel } \\
\text { cylinder }\end{array}$ \\
\hline HEU & $56238-81 \mathrm{~B}$ & $125 \mathrm{~g}$ & $93.1 \% \mathrm{U} 235$ & Sealed inside Lexan \\
\hline DU & & $3.3 \mathrm{~kg}$ & & $\begin{array}{l}4 \sim 6 \mathrm{~cm} \text { diameter steel } \\
\text { cylindrical container }\end{array}$ \\
\hline Yellowcake & & $413 g$ & $\begin{array}{l}\text { Nat. U: } 99.275 \% \text { U238, } 0.72 \% \\
\text { U235, } 0.0055 \% \text { U234 }\end{array}$ & $\begin{array}{l}\text { Sealed in glass inside a PVC } \\
\text { cylinder }\end{array}$ \\
\hline $\begin{array}{l}\text { Heisenberg } \\
\text { Cube }\end{array}$ & & 2" cube & $\begin{array}{l}\text { Nat. U: } 99.275 \% \text { U238, } 0.72 \% \\
\text { U235, } 0.0055 \% \text { U234 }\end{array}$ & $\begin{array}{l}\text { 2" cube sealed inside Lexan } \\
\text { cube }\end{array}$ \\
\hline
\end{tabular}

Table 3. NORM Sources

\begin{tabular}{ll}
\hline \multicolumn{1}{c}{ Source } & \multicolumn{1}{c}{ Major Activity } \\
\hline Zircon Sand & Ra-226, Th-232 \\
Ice Melt & K-40 \\
Kitty Litter & K-40, Th-232 \\
Tiles & K-40, Th-232 \\
Fertilizer & K-40 \\
Granite & K-40, Th-232 \\
Lanthanum Carbonate & La-138 \\
\hline
\end{tabular}




\subsection{Analysis of $\mathrm{Nal}(\mathrm{TI})$ Data}

The data obtained with the NaI(Tl) detectors was analyzed by Symetrica, and at PNNL using traditional spectral analysis and by using GADRAS.

\subsection{Analysis Results From Symetrica}

This section summarizes the report in the Appendix provided by Matt Dallimore et al. of Symetrica on their analysis. Symetrica's aim of the testing was to acquire data from SNM sources to which the Large Area Detector System (LADS) module had not previously been exposed. PNNL's aim for the testing was to observe the performance of Symetrica's algorithm for SNM and also for industrial sources and NORM.

Tests on plastic scintillator (PVT) were also a priority for PNNL, although these tests were not accomplished, as mentioned previously because of detector damage. Symetrica has reported previously on their PVT work, and they will perform further measurements with their next prototype. This PVT analysis is of very high interest and needs to be actively pursued.

The Symetrica systems use their own unique spectral analysis [Meng and Ramsden 2000]. This analysis incorporates knowledge of the intrinsic detector response to deconvolve a measured spectrum into a good approximation of the gamma-ray spectrum incident upon the detector. In this way the gamma rays that only partially interact in the detector (i.e., the Compton-scattered portion of the spectra) can be "reassigned" to full-energy peaks. This deconvolved spectrum is then analyzed for peaks that match a library.

Computer simulations using the Monte Carlo code GEANT is used to produce the response functions for each specific detector and measurement geometry. The response functions are then used in calculations with the unknown (measured) spectrum in an iterative procedure to obtain a calculated spectrum having the same number of counts as in the original spectrum but with the counts redistributed primarily into full-energy peaks.

The spectrum obtained from this processing has narrower peaks than those in the original spectrum. For $\mathrm{NaI}(\mathrm{Tl})$ data, this results in an apparent energy resolution that is two to three times better than that in the original spectrum. The narrow peaks make it easier to identify isotopes based on their characteristic peak energies. In addition, the narrow peaks help in resolving closely spaced peaks and determining their individual peak intensities (areas). The library of potential sources included the 40 isotopes typically used for SNM, industrial, and natural sources in spectral applications for national security applications [ANSI 2006].

Table 4 shows a summary of the isotopes identified during the measurements using Symetrica's analysis technique. The table shows various shielding configurations that lead to attenuation of the lines at $186 \mathrm{keV}$ for $\mathrm{HEU}$ or at $414 \mathrm{keV}$ for $\mathrm{Pu}$, with the corresponding success rate for identification of the nuclide. Even with a non-optimum detector system the LADS demonstrated excellent identification performance with WGPu, identifying it bare at a distance of $5.4 \mathrm{~m}$, as well as identifying the source through an inch of steel and copper shielding at a distance of $1 \mathrm{~m}$ in most of the 10 -second runs. The software was subsequently modified to the resolution specification of the PNNL detectors, and the results from that reanalysis are also presented in the table. For example, the WGPu source attenuated by $90 \%$ 
resulted in eight out of ten (8/10) correct identifications for the original calculation and 10/10 for the reanalysis with the appropriate energy resolution. Table 5 gives a summary of all the source identifications from the Symetrica system. Full results from Symetrica are given in the Appendix.

Table 4. Summary of Shielded-Source Identification From Symetrica

\begin{tabular}{|c|c|c|c|c|c|c|}
\hline \multirow[b]{2}{*}{$\begin{array}{c}\text { Attenuation Level @ } \\
414 \mathrm{keV}\end{array}$} & \multirow[b]{2}{*}{$\begin{array}{c}\text { Attenuation Level @ } \\
186 \mathrm{keV}\end{array}$} & \multirow[b]{2}{*}{$\begin{array}{l}\text { Identified As } \\
\text { Recorded }\end{array}$} & \multirow[b]{2}{*}{$\begin{array}{c}\text { Identified In } \\
\text { Reanalysis }\end{array}$} & \multicolumn{3}{|c|}{ Shielding materials } \\
\hline & & & & $\begin{array}{l}\text { Steel } \\
(\mathrm{mm})\end{array}$ & $\begin{array}{c}\text { Copper } \\
(\mathrm{mm})\end{array}$ & $\begin{array}{l}\text { Lead } \\
(\mathrm{mm})\end{array}$ \\
\hline $37 \% \mathrm{WGPu}$ & & $7 / 10$ & $10 / 10$ & 6.35 & & \\
\hline $75 \% \mathrm{WGPu}$ & & $9 / 10$ & $10 / 10$ & 19.05 & & \\
\hline $90 \% \mathrm{WGPu}$ & & $8 / 10$ & $10 / 10$ & 19.05 & 6.35 & \\
\hline $96 \% \mathrm{WGPu}$ & & $5 / 10$ & $7 / 10$ & 19.05 & 6.35 & 3.175 \\
\hline $100 \%$ WGPu & & $0 / 10$ & $1 / 10$ & & & 50.8 \\
\hline $37 \% \mathrm{RGPu}$ & & $5 / 10$ & $10 / 10$ & 6.35 & & \\
\hline $75 \% \mathrm{RGPu}$ & & $11 / 15$ & $12 / 15$ & 19.05 & & \\
\hline $90 \% \mathrm{RGPu}$ & & $3 / 5$ & $5 / 5$ & 19.05 & 6.35 & \\
\hline & $16 \% \mathrm{HEU}$ & $10 / 10$ & $10 / 10$ & 1.1 & & \\
\hline & $69 \%$ HEU & $10 / 10$ & $10 / 10$ & 7.5 & & \\
\hline & $87 \%$ HEU & $4 / 9$ & $9 / 9$ & 13.8 & & \\
\hline
\end{tabular}

Table 5. Summary of Source Identifications From Symetrica

\begin{tabular}{llll}
\hline \multicolumn{1}{c}{ Source } & \multicolumn{1}{c}{ Batch Results: } & \multicolumn{1}{c}{$\begin{array}{c}\text { Source Isotopes at }>=80 \% \\
\text { identification level }\end{array}$} & $\begin{array}{c}\text { Other Isotopes at }>=80 \% \\
\text { identification level }\end{array}$ \\
\hline Cs-137 & $4 / 4$ & Cs137 & \\
Co-57 & $4 / 6$ & Co57 19/30) & \\
Co-60 & $6 / 6$ & Co60 & \\
Ba-133 & $1 / 1$ & Ba133 & \\
Zircon Sand & $2 / 2$ & Ra226 & \\
Ice Melt & $1 / 1$ & K40 & \\
Kitty Litter & $0 / 1$ & (K40 5/10, Th232 5/10) & \\
Tiles & $1 / 1$ & K40 & \\
Fertilizer & $1 / 1$ & K40 & \\
Granite & $1 / 1$ & K40 & \\
Lanthanum Carbonate & $1 / 1$ & La138 & \\
WGPu & $7 / 8$ & Pu239 & (I123 29/45) \\
WGPu (shielded) & $6 / 9$ & (Pu239 32/45) & Sm153 \\
RGPu & $6 / 6$ & Am241 & \\
& & Pu241 & Cs137 \\
RGPu (shielded) & $5 / 6$ & Pu239 & \\
& & Pu241 & \\
HEU & & Am241 & \\
DU & $12 / 13$ & Pu239 & \\
Yellowcake & $3 / 4$ & U235 & \\
Heisenberg Cube & $5 / 5$ & U238 & \\
\hline
\end{tabular}




\subsection{Analysis Results Using GADRAS}

While the Symetrica systems incorporate their own unique spectral analysis package, the data were also analyzed at PNNL using the spectral analysis software package GADRAS. GADRAS uses a fullspectrum analysis method to analyze gamma-ray spectra, where an entire spectrum is convoluted with a detector response function and is then fitted with one or more computed spectral templates (template matching). These templates are computed using a detector response function that can be defined by the user to fit a specific detector.

The detector settings used to analyze the Symetrica data are shown in Figure 5. These settings characterize a 2"x4"x16" NaI crystal that is then scaled by two to represent both detectors in the Symetrica case. The calibration coefficients were determined using data collected by the system on several standard sources: ${ }^{137} \mathrm{Cs},{ }^{60} \mathrm{Co}$, and ${ }^{133} \mathrm{Ba}$.



Figure 5. Screen Capture of Detector Response Parameters

The data were analyzed in GADRAS using the DHS Isotope ID Fit-to-DB function. The library/database (DB) of isotopes contains 5 main categories: Natural, Industrial, Medical, SNM, and Beta. There are 46 isotopes in total that are used by GADRAS in the Fit-to-DB routine. The results show the initial gamma-ray spectrum in black markers and the solid color fills represent the isotopes detected by GADRAS. An example of one such spectrum is shown in Figure 6 for a ${ }^{60}$ Co source. 


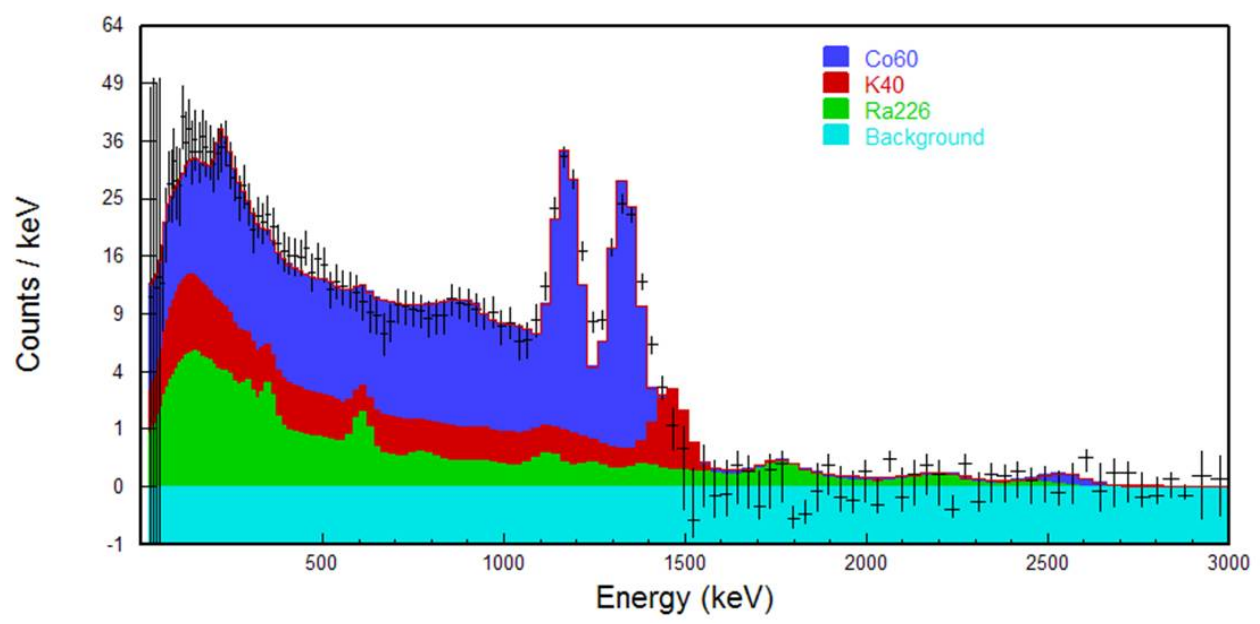

Figure 6. ${ }^{60} \mathrm{Co}$ Spectrum Analyzed in GADRAS

GADRAS correctly classified most of the sources and identified their main isotopes. It further categorized them by SNM probability and Threat Level. There are several instances where GADRAS identifies isotopes that were not present during data collection but acknowledges it as a weak ID with either fair or low confidence. The only Bad ID was on the NORM sample of lanthanum carbonate but it was still classified as a very low probability SNM. Table 6 summarizes the results from GADRAS. In the table, industrial sources are colored green, NORM sources are colored blue, and SNM sources are colored red. The data analyzed in GADRAS represents only a portion of all the data files collected by Symetrica. For each batch of data, there were at least 5 runs taken back to back on a given sample. The analysis in GADRAS included approximately 1 out of 5 runs for every sample. Table 6 has two columns with fractions listed. Those columns indicate the percentage of batch runs on a given source that GADRAS identified and classified consistently. For a detailed compilation of the GADRAS results for the individual runs, see Appendix Table C.1.

Table 7 is similar to Table 4 but includes a summary of the isotopes identified using GADRAS compared to those identified using the Symetrica technique. This table again shows various shielding configurations that lead to attenuation of the lines at $186 \mathrm{keV}$ for HEU or at $414 \mathrm{keV}$ for Pu, with the corresponding success rate for identification of the nuclide, this time using GADRAS. GADRAS successfully classified all of the WGPu, RGPu, and HEU data as High Probability SNM threats. It correctly identified the main isotope of the WGPu data for each shielding scenario except for $50.8 \mathrm{~mm}$ of Lead. In that case, it misidentified the main isotope but was still classified as a High Probability SNM threat. The RGPu data was correctly classified and identified for all runs, as was the HEU data. The complete GADRAS analysis of the SNM data is shown in Appendix Table D.2. 
Table 6. Summary of Source Identification in GADRAS

\begin{tabular}{|c|c|c|c|c|c|c|}
\hline Source & & A Probability & & Threat Level & Main Isotope(s) & $\begin{array}{l}\text { Additional Isotopes } \\
\text { (confidence level) }\end{array}$ \\
\hline Cs-137 & $4 / 4$ & 0 (Very Low) & $4 / 4$ & 3 (Industrial) & Cs137 & $\mathrm{n} / \mathrm{a}$ \\
\hline Co-57 & $6 / 6$ & 0 (Very Low) & $6 / 6$ & 3 (Industrial) & Co57 & $\mathrm{Na} 22$ (fair) \\
\hline Сo-60 & $6 / 6$ & 0 (Very Low) & $6 / 6$ & 3 (Industrial) & Co60 & Na22 (fair), Lu177m (fair) \\
\hline Ва-133 & $1 / 1$ & 0 (Very Low) & $1 / 1$ & 3 (Industrial) & Ba133 & Cf252 (fair) \\
\hline Zircon Sand & $1 / 2$ & 0 (Very Low) & $1 / 2$ & 3 (Suspect) & Ra226, Th232 & U238 \\
\hline Ice Melt & $1 / 1$ & 0 (Very Low) & $1 / 1$ & 4 (High Gamma) & K40, Th232 & $\mathrm{n} / \mathrm{a}$ \\
\hline Kitty Litter & $1 / 1$ & 2 (Fair) & $1 / 1$ & $6(\mathrm{SNM}=\mathrm{F})$ & K40, Th232 & U232 (fair) \\
\hline Tiles & $1 / 1$ & 0 (Very Low) & $1 / 1$ & 1 (Natural) & $\mathrm{K} 40$, Th232 & $\mathrm{n} / \mathrm{a}$ \\
\hline Fertilizer & $1 / 1$ & 0 (Very Low) & $1 / 1$ & 4 (High Gamma) & K40, Th232 & $\mathrm{n} / \mathrm{a}$ \\
\hline Granite & $1 / 1$ & 0 (Very Low) & $1 / 1$ & 1 (Natural) & K40, Th232 & $\mathrm{n} / \mathrm{a}$ \\
\hline $\begin{array}{l}\text { Lanthanum } \\
\text { Carbonate }\end{array}$ & $1 / 1$ & 0 (Very Low) & $1 / 1$ & $4(\mathrm{Bad} I D)$ & K40 & Ho166m (fair), Mn54 (fair) \\
\hline WGPu & $8 / 8$ & 3 (High) & $8 / 8$ & $7(\mathrm{SNM}=\mathrm{H})$ & $\mathrm{Pu} 239$ & U238 (fair), \\
\hline $\begin{array}{l}\text { WGPu } \\
\text { (shielded) }\end{array}$ & $9 / 9$ & 3 (High) & $9 / 9$ & $7(\mathrm{SNM}=\mathrm{H})$ & $\mathrm{Pu} 239$ & $\begin{array}{l}\text { Am241 (fair), T1201 (fair), } \\
\text { Cs137 (fair), Ba133 (fair), } \\
\text { U235 (fair), U238 (fair), } \\
\text { In111 (High), Np237 (High), } \\
\text { U237 (High), I123 (High) }\end{array}$ \\
\hline $\mathrm{RGPu}$ & $6 / 6$ & 3 (High) & $6 / 6$ & $7(\mathrm{SNM}=\mathrm{H})$ & $\begin{array}{l}\mathrm{Pu} 239, \mathrm{Am} 241 \\
\mathrm{U} 237\end{array}$ & $\begin{array}{l}\text { Th228 (fair), U238 (fair), } \\
\text { Co57 (fair), U235 (low) }\end{array}$ \\
\hline $\begin{array}{l}\text { RGPu } \\
\text { (shielded) }\end{array}$ & $6 / 6$ & 3 (High) & $6 / 6$ & $7(\mathrm{SNM}=\mathrm{H})$ & Am241, Pu239 & $\begin{array}{l}\text { Th232 (high), U238 (high), } \\
\text { U237 (high), U235 (fair), } \\
\text { Cs137 (high) }\end{array}$ \\
\hline HEU & $13 / 13$ & 3 (High) & $13 / 13$ & $7(\mathrm{SNM}=\mathrm{H})$ & U235 & U238 (fair) \\
\hline DU & $4 / 4$ & 2 (Fair) & $2 / 2$ & $6(\mathrm{SNM}=\mathrm{F})$ & U238 & $\mathrm{n} / \mathrm{a}$ \\
\hline Yellowcake & $5 / 6$ & 3 (High) & $5 / 6$ & $7(\mathrm{SNM}=\mathrm{H})$ & $\mathrm{U} 238$ & $\begin{array}{l}\text { Am241 (high), Pu239 (high), } \\
\text { U235 (high) }\end{array}$ \\
\hline $\begin{array}{l}\text { Heisenberg } \\
\text { Cube }\end{array}$ & $5 / 5$ & 2 (Fair) & $5 / 5$ & $6(\mathrm{SNM}=\mathrm{F})$ & $\mathrm{U} 238$ & U235 (fair) \\
\hline
\end{tabular}

Table 7. Summary of Shielded-Source Identification using GADRAS

\begin{tabular}{lcccccc}
\hline $\begin{array}{c}\text { Attenuation Level } \\
\text { @ } 414 \mathrm{keV}\end{array}$ & $\begin{array}{c}\text { Attenuation Level } \\
\text { @ } 186 \mathrm{keV}\end{array}$ & $\begin{array}{c}\text { Identified By } \\
\text { Symetrica }\end{array}$ & $\begin{array}{c}\text { Identified In } \\
\text { GADRAS }\end{array}$ & $\begin{array}{c}\text { Steel } \\
(\mathrm{mm})\end{array}$ & $\begin{array}{c}\text { Copper } \\
(\mathrm{mm})\end{array}$ & $\begin{array}{c}\text { Lead } \\
(\mathrm{mm})\end{array}$ \\
\hline $37 \% \mathrm{WGPu}$ & & $10 / 10$ & $10 / 10$ & 6.35 & & \\
$75 \% \mathrm{WGPu}$ & & $10 / 10$ & $10 / 10$ & 19.05 & & \\
$90 \% \mathrm{WGPu}$ & & $10 / 10$ & $10 / 10$ & 19.05 & 6.35 & \\
$96 \% \mathrm{WGPu}$ & & $7 / 10$ & $10 / 10$ & 19.05 & 6.35 & 3.175 \\
$100 \% \mathrm{WGPu}$ & & $1 / 10$ & $0 / 10$ & & & 50.8 \\
$37 \% \mathrm{RGPu}$ & & $10 / 10$ & $10 / 10$ & 6.35 & & \\
$75 \% \mathrm{RGPu}$ & & $12 / 15$ & $15 / 15$ & 19.05 & & \\
$90 \% \mathrm{RGPu}$ & & $5 / 5$ & $5 / 5$ & 19.05 & 6.35 \\
& $16 \% \mathrm{HEU}$ & $10 / 10$ & $10 / 10$ & 1.1 & & \\
& $69 \% \mathrm{HEU}$ & $10 / 10$ & $10 / 10$ & 7.5 & & \\
& $87 \% \mathrm{HEU}$ & $9 / 9$ & $9 / 9$ & 13.8 & &
\end{tabular}




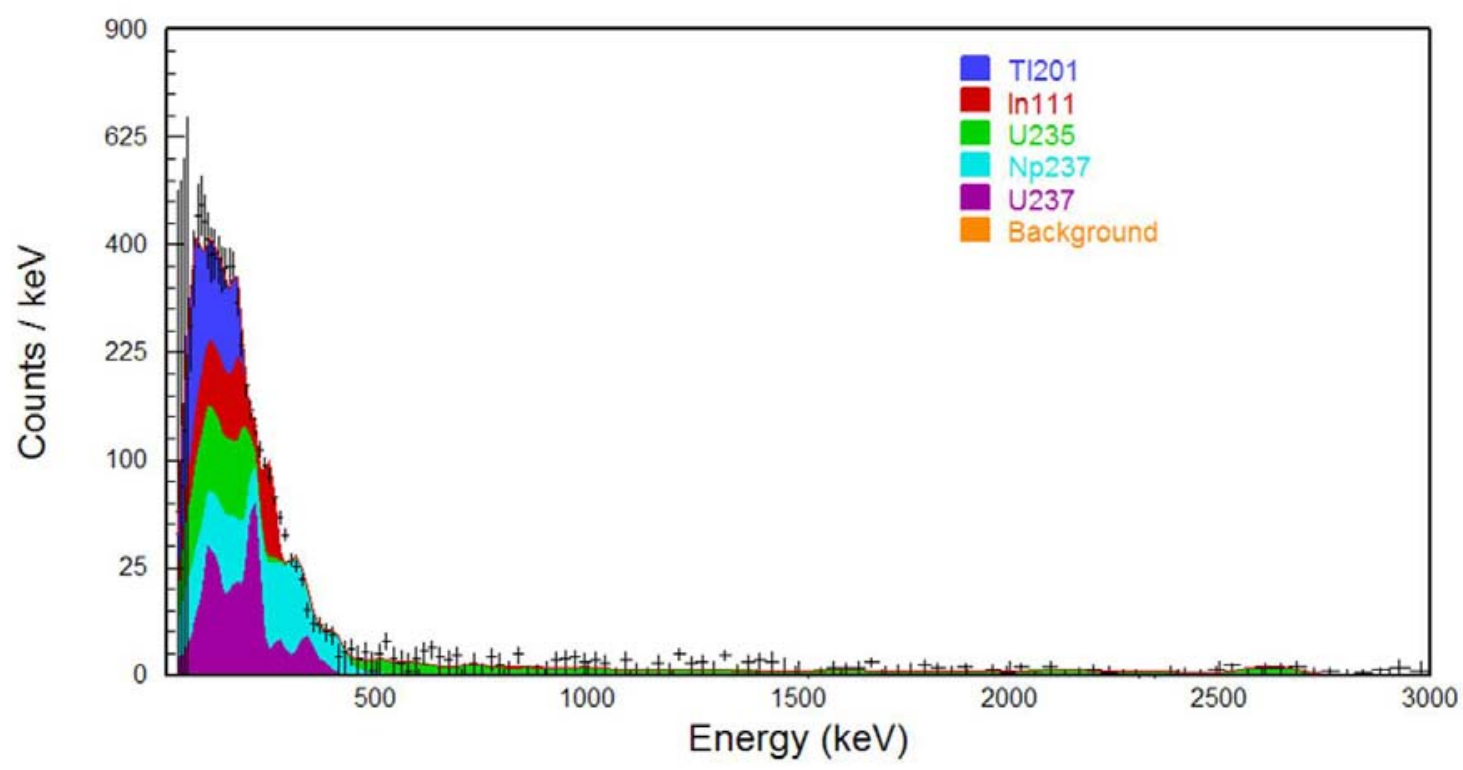

Figure 7. GADRAS Example of Misidentification but Correct Classification

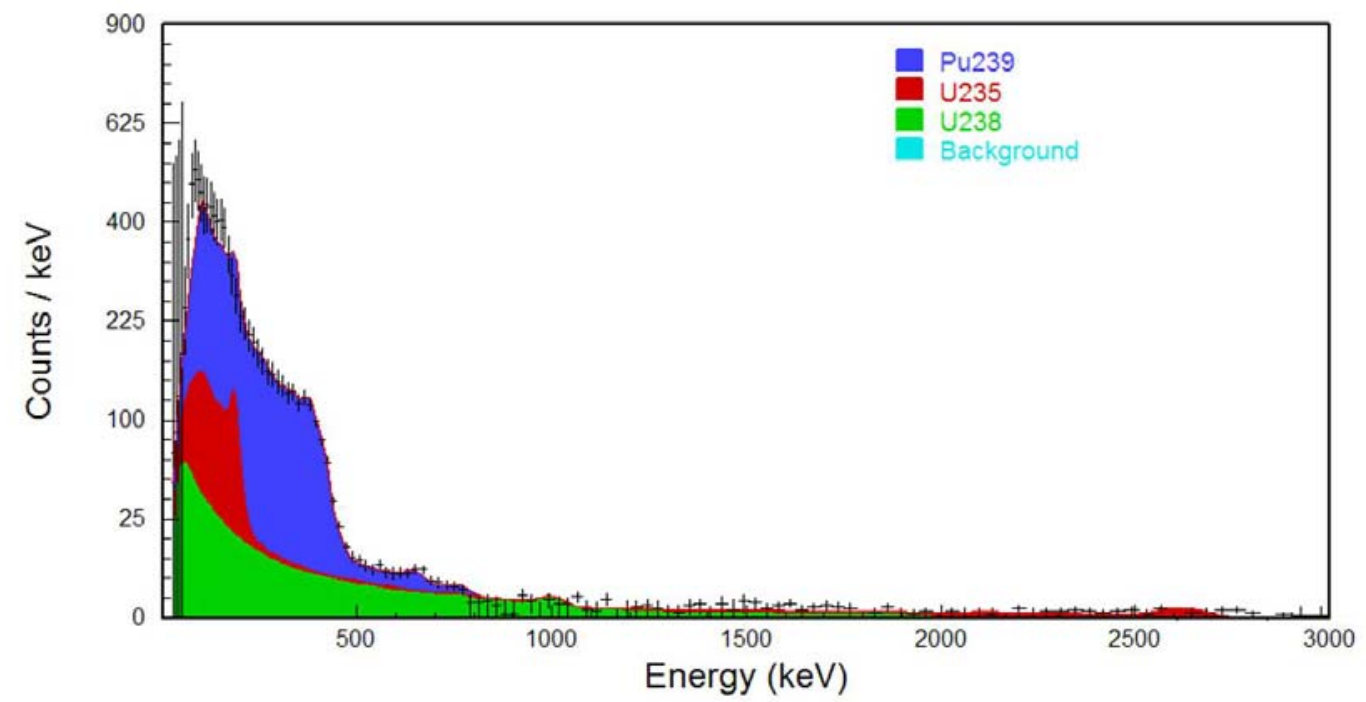

Figure 8. GADRAS Example of Correct Identification and Correct Classification

The results from GADRAS serve to confirm its excellent reputation for spectral analysis. The GADRAS analysis in the present tests was performed off-line, and for Guardian applications this would need to be done on-line. At least one commercial adaptation of GADRAS (leased to Thermo) exists for portal monitors. 


\subsection{Analysis Results Using ScintiVision}

The $\mathrm{NaI}(\mathrm{Tl})$ data were also analyzed at PNNL using the commercial, spectral analysis program ScintiVision-32 from ORTEC. ScintiVision (SV) was designed specifically for the unique characteristics of $\mathrm{NaI}(\mathrm{Tl})$ spectra. It uses a peak searching algorithm with a Gaussian cross correlation peak search that adapts to the resolution and peak shape of the particular $\mathrm{NaI}(\mathrm{Tl})$ detector being used. Multiplets located by the peak search process are deconvoluted by a method that allows the number of peaks, the peak positions, and their width and area to vary until the minimum value of Chi-squared is obtained. This is intended to ensure that positive identification is statistically reasonable.

The library that SV uses to find the peaks can be user defined. For this analysis, a library was created by using every peak previously identified by the GADRAS method, including misidentifications, and then by going through the Symetrica data files and adding any other isotopes that were not previously included. The library had 34 nuclides and 146 peaks, which are listed in the Appendix.

Table 8 contains a summary of the ScintiVision results, with more complete results being contained in the Appendix. SV was not as useful as GADRAS when identifying isotopes in many spectra. It correctly identified the main isotope in most cases but also identified multiple other sources as well. Most of the superfluous peak identification occurred in the lower energy region circled in Figure 9. Figure 9 shows a ${ }^{60} \mathrm{Co}$ spectrum with the analysis results listed above the plot. The ${ }^{60} \mathrm{Co}$ peaks at $1173 \mathrm{keV}$ and $1332 \mathrm{keV}$ are easily found by the peak search but in the lower energy region, it erroneously finds ${ }^{166 \mathrm{~m}} \mathrm{Ho},{ }^{238} \mathrm{U},{ }^{177 \mathrm{~m}} \mathrm{Lu}$, and ${ }^{232} \mathrm{U}$. It appears that the peak identification algorithm is extremely sensitive to the user-defined library.

The problem of identifying erroneous nuclides is particularly significant for radiation portal monitors. Numerous false alarms and incorrect nuclide identifications effectively negate the potential benefits provided by spectral analysis. Thus, SV appears to be unsuitable for direct use for $\mathrm{NaI}(\mathrm{Tl})$-based portal monitor applications unless improvements in the nuclide identification part of the software can be achieved.

Table 8. Summary of Source Identification in ScintiVision

\begin{tabular}{|c|c|c|c|c|}
\hline Source & $\begin{array}{l}\text { Number of } \\
\text { Runs }\end{array}$ & Main Isotopes & $\begin{array}{l}\text { Additional Isotopes } \\
\text { Identified }\end{array}$ & $\begin{array}{l}\text { Improbable Isotopes Found } \\
\text { (High Uncertainty) }\end{array}$ \\
\hline Cs-137 & $4 / 4$ & Cs137 & K40, Th232 & $\begin{array}{l}\text { Ba133, Co57, Eu152, Pu239, Se75, U232, } \\
\text { U233 }\end{array}$ \\
\hline Co-57 & $1 / 6$ & $\begin{array}{l}\text { Co57, Se75, } \\
\text { Ga67 }\end{array}$ & K40, Th232 & $\begin{array}{l}\text { Ba133, Co60, Eu152, I123, In111, } \\
\text { Lu177m, Np237, Ra226, U232, U238 }\end{array}$ \\
\hline Co-60 & $5 / 6$ & Co60 & K40, Th232 & $\begin{array}{l}\text { Ba133, Cr51, Eu152, I123, Ir192, } \\
\text { Lu177m, Pu241, Ra226, U232, U235 }\end{array}$ \\
\hline Ва-133 & $0 / 1$ & Eu152, Pu239 & K40, Th232 & Ra226, Se75, U232 \\
\hline $\begin{array}{l}\text { Zirc Sand } \\
\text { Ice Melt }\end{array}$ & $\begin{array}{l}2 / 2 \\
1 / 1\end{array}$ & $\begin{array}{l}\text { Ra226, Th232 } \\
\text { K40 }\end{array}$ & K40 & Ba133, Eu152, Lu177m, Mo99, U232 \\
\hline Kitty Litter & $1 / 1$ & K40 & Ra226 & Eu152, Se75, U232 \\
\hline Tiles & $1 / 1$ & K40 & $\operatorname{Ra} 226$ & \\
\hline Fertilizer & $1 / 1$ & K40 & & \\
\hline Granite & $1 / 1$ & K40, Th232 & $\mathrm{Ra} 226$ & Eu152 \\
\hline $\begin{array}{l}\text { Lanthanum } \\
\text { Carbonate }\end{array}$ & $1 / 1$ & K40, Th232 & & \\
\hline
\end{tabular}


Table 8. (contd)

\begin{tabular}{|c|c|c|c|c|}
\hline Source & $\begin{array}{c}\text { Number of } \\
\text { Runs }\end{array}$ & Main Isotopes & $\begin{array}{l}\text { Additional Isotopes } \\
\text { Identified }\end{array}$ & $\begin{array}{l}\text { Improbable Isotopes Found } \\
\text { (High Uncertainty) }\end{array}$ \\
\hline WGPu & $3 / 8$ & $\mathrm{Pu} 241$ & K40, Th232 & $\begin{array}{l}\text { Co57, I123, I131, In111, Lu177m, Mo99, } \\
\text { Ra226, Se75, Sm153, T1201, U235 }\end{array}$ \\
\hline $\begin{array}{l}\text { WGPu } \\
\text { (shielded) }\end{array}$ & $5 / 9$ & $\begin{array}{l}\text { Pu239, U238, } \\
\text { U235, U233, } \\
\text { U232 }\end{array}$ & K40, Ra226, Th232 & $\begin{array}{l}\text { Co57, Co60, Ho166m, I123, Lu177m, } \\
\text { Mo99, Se75 }\end{array}$ \\
\hline $\mathrm{RGPu}$ & $1 / 6$ & Np237 & $\begin{array}{l}\text { Cs137, Ga67, K40, } \\
\text { Th232 }\end{array}$ & Ba133, Cr51, Eu152, I123, Ra226 \\
\hline $\begin{array}{l}\text { RGPu } \\
\text { (shielded) }\end{array}$ & $3 / 6$ & $\begin{array}{l}\text { Pu239, U232, } \\
\text { U233 }\end{array}$ & Cs137, K40, Th232 & $\begin{array}{l}\text { I123, Cr51, Mo99, Co57, I131, In111, } \\
\text { Bi207, Lu177m }\end{array}$ \\
\hline HEU & $4 / 13$ & $\begin{array}{l}\mathrm{U} 235, \mathrm{U} 232, \\
\mathrm{U} 233\end{array}$ & $\begin{array}{l}\text { Cs137, Pu241, K40, } \\
\text { Th232 }\end{array}$ & Sm153, I123, Ga67, In111 \\
\hline DU & $2 / 4$ & $\mathrm{U} 232, \mathrm{U} 238$ & K40, Th232 & Ra226, Se75, In111, Eu152, Cr51, Mo99, \\
\hline Yellowcake & $4 / 6$ & $\mathrm{U} 238$ & K40, Th232 & $\begin{array}{l}\text { Ba133, Np237, Cs137, Se75, Ra226, } \\
\text { Sm153, Mo99, U233 }\end{array}$ \\
\hline $\begin{array}{l}\text { Heisenberg } \\
\text { Cube }\end{array}$ & $4 / 5$ & $\mathrm{U} 238, \mathrm{U} 235$ & $\mathrm{~K} 40, \mathrm{Th} 232$ & $\begin{array}{l}\text { In111, Se75, Ho166m, Mo99, Ba133, } \\
\text { U233, U232, Pu239 }\end{array}$ \\
\hline
\end{tabular}

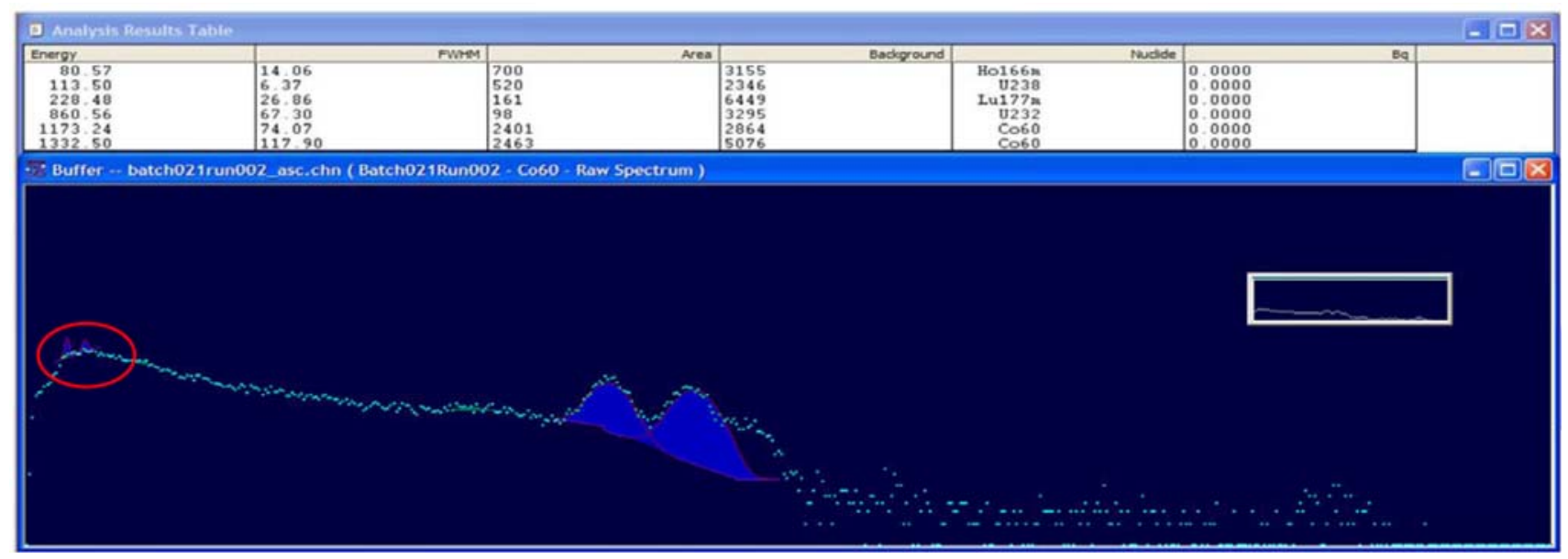

Figure 9. ${ }^{60}$ Co spectrum Analyzed in ScintiVision 


\subsection{Conclusions}

The results of measurements made at PNNL with Symetrica are encouraging. In general, Symetrica's analysis correctly identified the isotopes present during the experiments. Comparison of these results to those of GADRAS and ScintiVision showed that GADRAS also performed well in isotope identification, but that ScintiVision did not perform well for this application.

While GADRAS correctly identified the same isotopes as the Symetrica analysis for the LADS $\mathrm{NaI}(\mathrm{Tl})$ based system, it would be interesting to see how the Symetrica analysis technique handles multiple sources or mixtures of sources. A comparison should be made of GADRAS and Symetrica performance for such complex source mixtures.

During testing at PNNL, the PVT analysis portion of Symetrica's algorithm was not tested due to damage/degradation of the system. The potential use of PVT for isotopic identification requires an improved hardware configuration and specialized software analysis. It may turn out that the analysis by Symetrica using spectral deconvolution is more applicable than GADRAS when it comes to isotope identification in PVT detectors, but this should be investigated. The application of Symetrica's analysis to PVT is of very high interest and should be pursued further.

GADRAS is well established as an isotope-identification program for homeland security applications. The brief experiments reported here with Symetrica's analysis technique also showed good results, indicating that their technique warrants further evaluation for homeland security applications, such as with $\mathrm{NaI}(\mathrm{Tl})$ and PVT-based radiation detectors. 


\subsection{Recommendations}

Since the results from the NaI(Tl) detector measurements at PNNL and previous results by Symetrica with PVT have been promising, it is recommended that further work be performed. Specifically, the following steps should be taken:

1. The Symetrica $\mathrm{NaI}(\mathrm{Tl})$ system should be considered for inclusion in the testing of spectroscopic systems that is planned for Guardian, if Symetrica can provide a near-deployable system such as they used in the Advanced Spectroscopic Portal testing.

2. Since the cost savings for an improved PVT system could be substantial, Guardian should consider providing funds for Symetrica to assemble an improved prototype PVT system for further testing. This system should be tested side-by-side with both standard PVT systems and spectroscopic portal systems.

3. Since the development of the PVT system for a deployable system may take a year or more for validation, the pursuit of this option may need to be, in the near term, in addition to the deployment of current Guardian systems.

4. Future testing should include, in addition to standard sources and NORM, the Guardian threat basis and combinations of sources. Comparative analysis with GADRAS should be included in this work. 


\subsection{References}

ANSI. 2006. American National Standard Performance Criteria for Spectroscopy-Based Portal Monitors Used for Homeland Security, ANSI N42.38-2006. Institute of Electrical and Electronics Engineers, New York, New York.

Burt CJ. 2008. University of Southampton, UK; D Ramsden, Symetrica Ltd, UK, "Recent Advances in the Development of Large-Area Plastic Gamma-Ray Spectrometers," Institute of Electrical and Electronics Engineers, NSS Dresden Conference Record, October 2008.

Crossingham G, M Dallimore, and D Ramsden. 2003. “The Effect of Counting Statistics on the Integrity of Deconvolved Gamma-Ray Spectra." In Nuclear Science Symposium Conference Record, 2003 IEEE, Vol 1, pp. 696-700. Piscataway, New Jersey.

Dallimore M, G Crossingham, and D Ramsden. 2003. "High-resolution Scintillation Spectrometers for Neutron-activation Analysis." In Nuclear Science Symposium Conference Record, 2003 IEEE, Vol 2, pp. 704-707. Piscataway, New Jersey.

Foster MA. 2008. University of Southampton, UK; D. Ramsden, Symetrica Ltd, UK, "Progress Towards the Development of Practical Scintillation Counters Based on SiPM Devices." Institute of Electrical and Electronics Engineers, NSS Dresden Conference Record.

Meng LJ and D Ramsden. 2000. “An Inter-Comparison of Three Spectral-Deconvolution Algorithms for Gamma-Ray Spectroscopy.” IEEE Transactions on Nuclear Science 47(4):1329-1335.

Ramsden D and M Dallimore. In Press, 2008. "Large Volume PVT Detectors Having Spectroscopic Capability." Symetrica Ltd, UK, in press. 


\section{Appendix A \\ Measurements Performed}





\section{Appendix A \\ Measurements Performed}

Table A.1. Summary of Measurements Performed

\begin{tabular}{|c|c|c|c|c|c|c|c|}
\hline $\begin{array}{c}\text { Batch } \\
\text { Number }\end{array}$ & Source & $\begin{array}{c}\text { distance } \\
\mathrm{cm}\end{array}$ & $\begin{array}{c}\text { time } \\
\mathrm{s} \\
\end{array}$ & runs & $\begin{array}{r}\text { shielding } \\
\text { material }\end{array}$ & $\begin{array}{c}\text { thickness } \\
\mathrm{mm}\end{array}$ & Date \\
\hline 2 & WGPu 98g & 300 & 10 & 5 & can SS & 0.635 & $3 / 11 / 08$ \\
\hline 3 & WGPu 98g & 300 & 10 & 5 & can SS & 0.635 & $3 / 11 / 08$ \\
\hline 4 & WGPu 98g & 300 & 10 & 5 & can SS & 0.635 & $3 / 11 / 08$ \\
\hline 5 & WGPu 98g & 300 & 10 & 5 & can SS & 0.635 & $3 / 11 / 08$ \\
\hline 6 & WGPu 98g & 420 & 10 & 5 & can SS & 0.635 & $3 / 11 / 08$ \\
\hline 7 & WGPu 98g & 420 & 10 & 5 & can SS & 0.635 & $3 / 11 / 08$ \\
\hline 8 & WGPu 98g & 530 & 10 & 5 & can SS & 0.635 & $3 / 11 / 08$ \\
\hline 9 & WGPu 98g & 530 & 10 & 5 & can SS & 0.635 & $3 / 11 / 08$ \\
\hline 11 & RGPu 98g & 300 & 10 & 5 & can SS & 0.635 & $3 / 11 / 08$ \\
\hline 12 & RGPu 98g & 300 & 10 & 5 & can SS & 0.635 & $3 / 11 / 08$ \\
\hline 13 & RGPu 98g & 420 & 10 & 5 & can SS & 0.635 & $3 / 11 / 08$ \\
\hline 14 & RGPu 98g & 420 & 10 & 5 & can SS & 0.635 & $3 / 11 / 08$ \\
\hline 15 & RGPu 98g & 530 & 10 & 5 & can SS & 0.635 & $3 / 11 / 08$ \\
\hline 16 & RGPu 98g & 530 & 10 & 5 & can SS & 0.635 & $3 / 11 / 08$ \\
\hline 17 & Cs137 & 200 & 10 & 5 & & & $4 / 11 / 08$ \\
\hline 18 & Cs137 & 200 & 10 & 5 & & & $4 / 11 / 08$ \\
\hline 19 & Cs137 & 300 & 10 & 5 & & & $4 / 11 / 08$ \\
\hline 20 & Cs137 & 300 & 10 & 5 & & & $4 / 11 / 08$ \\
\hline 21 & Co60 & 100 & 10 & 5 & & & $4 / 11 / 08$ \\
\hline 22 & Co60 & 100 & 10 & 5 & & & $4 / 11 / 08$ \\
\hline 23 & Co60 & 200 & 10 & 5 & & & $4 / 11 / 08$ \\
\hline 24 & Co60 & 200 & 10 & 5 & & & $4 / 11 / 08$ \\
\hline 25 & Co60 & 300 & 10 & 5 & & & $4 / 11 / 08$ \\
\hline 26 & Co60 & 300 & 10 & 5 & & & $4 / 11 / 08$ \\
\hline 27 & DU 3.3kg & 100 & 10 & 5 & & & $4 / 11 / 08$ \\
\hline 28 & DU 3.3kg & 100 & 10 & 5 & & & $4 / 11 / 08$ \\
\hline 29 & DU 3.3kg & 50 & 10 & 5 & & & $4 / 11 / 08$ \\
\hline 30 & DU 3.3kg & 50 & 10 & 5 & & & $4 / 11 / 08$ \\
\hline 31 & Co57 & 50 & 10 & 5 & & & $4 / 11 / 08$ \\
\hline 32 & Co57 & 50 & 10 & 5 & & & $4 / 11 / 08$ \\
\hline 33 & Co57 & 200 & 10 & 5 & & & $4 / 11 / 08$ \\
\hline 34 & Co57 & 200 & 10 & 5 & & & $4 / 11 / 08$ \\
\hline 35 & Co57 & 100 & 10 & 5 & & & $4 / 11 / 08$ \\
\hline 36 & Co57 & 100 & 10 & 5 & & & $4 / 11 / 08$ \\
\hline 37 & Ba133 & 100 & nts batch & & & & 4/11/08 \\
\hline
\end{tabular}


Table A.1. (contd)

\begin{tabular}{|c|c|c|c|c|c|c|c|}
\hline $\begin{array}{c}\text { Batch } \\
\text { Number }\end{array}$ & Source & $\begin{array}{c}\text { distance } \\
\mathrm{cm}\end{array}$ & $\begin{array}{c}\text { time } \\
\mathrm{s} \\
\end{array}$ & runs & $\begin{array}{c}\text { shielding } \\
\text { material }\end{array}$ & $\begin{array}{c}\text { thickness } \\
\mathrm{mm}\end{array}$ & Date \\
\hline 38 & Zircon Sand & 100 & 30 & 7 & & & $4 / 11 / 08$ \\
\hline 39 & Zircon Sand & 11.43 & 10 & 10 & & & $4 / 11 / 08$ \\
\hline 40 & Ice Melt & contact & 10 & 30 & & & $4 / 11 / 08$ \\
\hline 41 & Kitty Litter & contact & 10 & 30 & & & $4 / 11 / 08$ \\
\hline 42 & Tiles & contact & 10 & 30 & & & $4 / 11 / 08$ \\
\hline 43 & Fertilizer & contact & 10 & 30 & & & $4 / 11 / 08$ \\
\hline 44 & $\begin{array}{l}\text { Granite } \\
\text { Lanthanum }\end{array}$ & contact & 10 & 30 & & & $4 / 11 / 08$ \\
\hline 45 & Carbonate & contact & 10 & 30 & & & $4 / 11 / 08$ \\
\hline 46 & HEU 125g & 100 & 10 & 5 & & & $5 / 11 / 08$ \\
\hline 47 & HEU 125g & 100 & 10 & 5 & & & $5 / 11 / 08$ \\
\hline 48 & HEU 125g & 200 & 10 & 5 & & & $5 / 11 / 08$ \\
\hline 49 & HEU 125g & 200 & 10 & 5 & & & $5 / 11 / 08$ \\
\hline 48 & HEU 125g & 300 & 10 & 5 & & & $5 / 11 / 08$ \\
\hline 49 & HEU 125g & 300 & 10 & 5 & & & $5 / 11 / 08$ \\
\hline 50 & HEU 125g & 400 & 10 & 5 & & & $5 / 11 / 08$ \\
\hline 51 & HEU 125g & 400 & 10 & 5 & & & $5 / 11 / 08$ \\
\hline 52 & HEU 125g & 400 & 10 & 5 & & & $5 / 11 / 08$ \\
\hline 53 & HEU 125g & 100 & 10 & 5 & steel plate & 1.1 & $5 / 11 / 08$ \\
\hline 54 & HEU 125g & 100 & 10 & 5 & steel plate & 1.1 & $5 / 11 / 08$ \\
\hline 55 & HEU 125g & 100 & 10 & 5 & steel plate & 7.5 & $5 / 11 / 08$ \\
\hline 56 & HEU 125g & 100 & 10 & 5 & steel plate & 7.5 & $5 / 11 / 08$ \\
\hline 57 & HEU 125g & 100 & 10 & 5 & steel plate & 13.8 & $5 / 11 / 08$ \\
\hline 58 & HEU 125g & 100 & 10 & 5 & steel plate & 13.8 & $5 / 11 / 08$ \\
\hline 61 & WGPu 98g & 100 & 10 & 5 & steel plate & 6.35 & $3 / 11 / 08$ \\
\hline 62 & WGPu 98g & 100 & 10 & 5 & steel plate & 6.35 & $3 / 11 / 08$ \\
\hline 63 & WGPu 98g & 100 & 10 & 5 & steel plate & 19.05 & $3 / 11 / 08$ \\
\hline 64 & WGPu 98g & 100 & 10 & 5 & steel plate & 19.05 & $3 / 11 / 08$ \\
\hline 65 & WGPu 98g & 100 & 10 & 5 & steel $+\mathrm{Cu}$ & 19.05 & $3 / 11 / 08$ \\
\hline 66 & WGPu 98g & 100 & 10 & 5 & steel $+\mathrm{Cu}$ & 19.05 & $3 / 11 / 08$ \\
\hline 65 & WGPu 98g & 100 & 10 & 5 & steel $+\mathrm{Cu}$ & 19.05 & $3 / 11 / 08$ \\
\hline 66 & WGPu 98g & 100 & 10 & 5 & steel $+\mathrm{Cu}$ & 19.05 & $3 / 11 / 08$ \\
\hline 69 & WGPu 98g & 100 & 10 & 5 & $\mathrm{~Pb}$ & 50.8 & $3 / 11 / 08$ \\
\hline 70 & WGPu 98g & 100 & 10 & 5 & $\mathrm{~Pb}$ & 50.8 & $3 / 11 / 08$ \\
\hline 71 & RGPu 98g & 100 & 10 & 5 & steel plate & 6.35 & $3 / 11 / 08$ \\
\hline 72 & RGPu 98g & 100 & 10 & 5 & steel plate & 6.35 & $3 / 11 / 08$ \\
\hline 73 & RGPu 98g & 100 & 10 & 5 & steel plate & 19.05 & $3 / 11 / 08$ \\
\hline 74 & RGPu 98g & 100 & 10 & 5 & steel plate & 19.05 & $3 / 11 / 08$ \\
\hline 75 & RGPu 98g & 100 & 10 & 5 & steel plate & 19.05 & $3 / 11 / 08$ \\
\hline
\end{tabular}


Table A.1. (contd)

\begin{tabular}{rlrrrrrr}
\hline $\begin{array}{c}\text { Batch } \\
\text { Number }\end{array}$ & Source & $\begin{array}{c}\text { distance } \\
\mathrm{cm}\end{array}$ & $\begin{array}{c}\text { time } \\
\text { s }\end{array}$ & runs & $\begin{array}{c}\text { shielding } \\
\text { material }\end{array}$ & $\begin{array}{c}\text { thickness } \\
\text { mm }\end{array}$ & Date \\
\hline 77 & RGPu 98g & 100 & 10 & 5 & steel $+\mathrm{Cu}$ & 19.05 & $3 / 11 / 08$ \\
78 & Yellowcake & 50 & 10 & 5 & & & \\
79 & Yellowcake & 50 & 10 & 5 & & & \\
80 & Yellowcake & 50 & 10 & 5 & & & \\
81 & Yellowcake & 50 & 10 & 5 & & & \\
82 & Heisenberg & 100 & 10 & 5 & & & \\
83 & Heisenberg & 100 & 10 & 5 & & & \\
84 & Heisenberg & 50 & 10 & 5 & & & \\
85 & Heisenberg & 50 & 10 & 5 & & & \\
87 & Heisenberg & 50 & 30 & 10 & & & \\
88 & Yellowcake & 50 & 30 & 10 & & & \\
89 & Yellowcake & 50 & 30 & 10 & steel plate & & \\
\end{tabular}





\section{Appendix B \\ Summary of Measurements Made at PNNL}





\section{Appendix B Summary of Measurements Made at PNNL}

This section provides a log of the measurements made over the three-day visit by Symetrica, and is presented as a record of the activities.

\section{Participants}

Symetrica: Matthew Dallimore, Thomas Meeks

PNNL: Richard Kouzes, Emily Mace, Rebecca Redding, David Stromswold

\section{Day 1: Monday, Nov. 3, 2008}

Location: $326 / 25 \mathrm{~A}$

Room Setup: Figure B.1



Figure B.1. Room Setup in 326/25A

At the beginning of Day 1, Symetrica took several batch runs of data using their NaI detectors and PVT.

It was determined that the two NaI detectors from Symetrica were damaged in transit from the UK and were then swapped out for two NaI from PNNL (borrowed from M. Myjak). The PVT was also not performing as expected so the two 5" PMTs were removed, cleaned, and reapplied. This did not solve the issue, and so there are very few PVT data runs. 
Data were collected on industrial, SNM, and NORM sources. These runs were collected on both bare sources at varying distances and then shielded sources at a fixed distance. Specific information on the source, location, and shielding for each data run can be found in Appendix A.

The industrial sources were placed on a tripod at a height above the floor of $50 \mathrm{~cm}$. The SNM sources were placed on the seat of a chair due to the awkwardness of the sealed containers and the weight of the sources. The height from the seat of the chair to the floor was $48 \mathrm{~cm}$, which is comparable to the height of the tripod at $50 \mathrm{~cm}$. Table B.1 shows the radiation dose rate (background subtracted) measured by a Bicron MicroRem meter at various distances from the sources, with an uncertainty of about $1 \mu \mathrm{R} / \mathrm{hr}$. Dose was measured since some standards have requirements stated in dose.

Table B.1. Rates during Data Runs

\begin{tabular}{lll}
\hline \multicolumn{1}{c}{ Isotope } & Distance $(\mathrm{cm})$ & Net Rate $(\mu \mathrm{R} / \mathrm{hr})$ \\
\hline Background (day1) & $\ldots$. & 10 \\
WGPu & 100 & 75 \\
& 50 & 200 \\
RGPu & 100 & 140 \\
& 50 & 420 \\
\hline
\end{tabular}

Day 2: Tuesday, Nov. 4, 2008

Location: First half day at $326 / 25 \mathrm{~A}$, last half day at $331 \mathrm{G}$

Setup: 326/25A shown previously in Figure B.1; 331G shown in Figure B.2

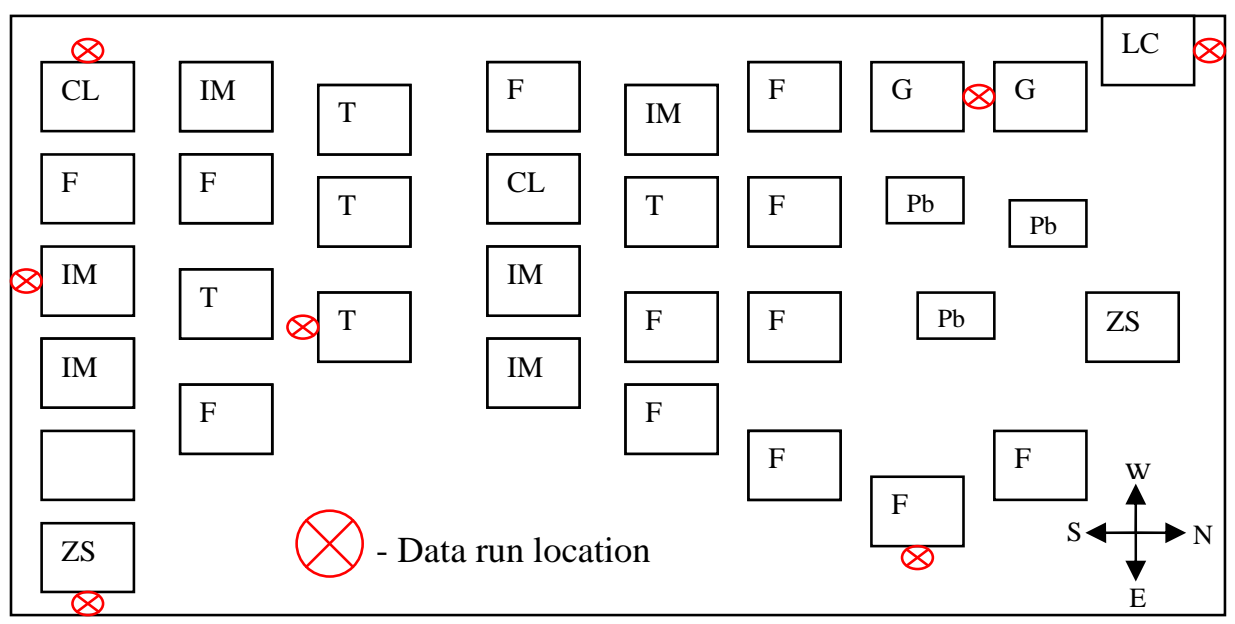

*Not to scale

Figure B.2. NORM sources at 331G

The first half of Day 2 was spent collecting data on the industrial sources at various distances. Table B. 2 shows the dose rates from these sources. In preparation for the second half of the day outside at $331 \mathrm{G}$, one of the $\mathrm{NaI}(\mathrm{Tl})$ detectors was removed from the case and the remaining $\mathrm{NaI}(\mathrm{Tl})$ was layered with additional foam for thermal insulation and vibration isolation. 
The last half of Day 2 was spent collecting data from the NORM sources at 331G. The NaI(Tl) was then brought back into $326 / 25 \mathrm{~A}$ to readjust to the temperature.

Table B.2. Rates during Data Runs

\begin{tabular}{lll}
\hline \multicolumn{1}{c}{ Isotope } & Distance $(\mathrm{cm})$ & Net Rate $(\mu \mathrm{R} / \mathrm{hr})$ \\
\hline Background (day2) & $\ldots$ & 9 \\
Cs-137 & 100 & 6 \\
& 50 & 12 \\
& 20 & 70 \\
Co-60 & 50 & 40 \\
& 20 & 170 \\
DU & 50 & 23 \\
& 20 & 110 \\
Co-57 & 20 & 3 \\
Ba-133 & 50 & 11 \\
& 20 & 60 \\
\hline
\end{tabular}

Day3: Wednesday, Nov. 5, 2008

Location: $326 / 25 \mathrm{~A}$

Setup: as shown previously in Figure B.1

Day 3 began by replacing the second NaI detector back in the case with the first and allowing the system to stabilize. After the system was calibrated and had collected a background, data were collected on the remaining SNM material and then various types of shielding were introduced. There were varying thicknesses of steel, lead, copper, and aluminum. The total amount of shielding used in each data run is listed in the log file from Symetrica as mentioned previously. Table B.3 shows the dose rates at various distances from the unshielded sources.

Table B.3. Rates during Data Runs

\begin{tabular}{lll}
\hline \multicolumn{1}{c}{ Isotope } & Distance $(\mathrm{cm})$ & Net Rate $(\mu \mathrm{R} / \mathrm{hr})$ \\
\hline Background (day3) & $\ldots$. & 8 \\
HEU & 50 & 9 \\
U (Yellowcake) & 50 & 5 \\
& 20 & 50 \\
U (Heisenberg Cube) & 50 & 11 \\
& 20 & 11 \\
\hline
\end{tabular}

It is noted that the measured background rate varied from 8 to $10 \mu \mathrm{R} / \mathrm{hr}$ over the three days of measurements, which was within the measurement error of the instrument used, though there may have been some change in radon levels due to weather changes. 

Appendix C
Symetrica Results (by M. Dallimore et al.)

C. 1 



\section{Appendix C \\ Symetrica Results (by M. Dallimore et al.)}

\section{C.1 Executive Summary}

This report presents the results of testing performed at PNNL on November 3-5, 2008. The aim of the testing was to acquire data from SNM sources that the LADS module has not previously been exposed. Upon arrival at PNNL it was discovered that the $\mathrm{NaI}(\mathrm{Tl})$ detectors had been damaged in transit. Replacement detectors were loaned from PNNL to replace those damaged. Even with a non-optimum detector system the LADS demonstrated excellent identification performance with WGPu, identifying the $125 \mathrm{~g}$ at a distance of $5.4 \mathrm{~m}$, as well as identifying the source through an inch of steel and copper. The software was subsequently modified to the specification of the detectors from PNNL and the results from that analysis are also presented.

\section{C.2 System Description - Large Area Detector System (LADS)}

The LADS is a scalable $\mathrm{NaI}(\mathrm{Tl})$ based radiation detection and identification system. The system is modular with each module based upon the use of two 2"x4"x16" NaI detectors in a single robust module. These modules can be networked together, increasing sensitivity to meet the particular requirement of the deployment. A two-module deployment, suitable for private vehicles can be seen in Figure C.1.



Figure C.1. LADS - Two Module Configuration 
A single module LADS was shipped for testing at PNNL. The two detectors were damaged in transit and replaced with two units loaned from PNNL, having an energy resolution of $8.5 \%$, compared with the original units that had a resolution of $7 \%$. The Symetrica algorithms are reasonably tolerant to nominally identical detectors, and this change did not affect the main purpose of data collection. However, some performance would have been compromised. The analysis software has been modified, in line with the resolution of the loaned detectors, and the results of the re-analyzed data is presented in the following sections.

\section{C.3 System description - Software}

\section{Isotope Identification}

The Symetrica approach to isotope identification is two-fold, firstly deconvolution of the spectra, followed by the application of the isotope identification algorithms to correlate the lines identified in the spectra with an isotope library. The deconvolution step clarifies the spectra through the re-positioning of that component of Compton-scattering that occurs within the detector itself. This provides accurate locations and intensities of spectral features and is achieved by combining knowledge of the physical properties of the detector with its energy-response function. That is, the measure of its energy-resolution as a function of the incident photon energy. This technique has been successfully applied to improving the performance of a wide range of detector designs and scintillator materials. This range includes small $\mathrm{NaI}(\mathrm{Tl})$ probes for intra-operative applications in nuclear medicine, to large 5"x6" detectors for neutron activation gamma-ray spectroscopy.

In the case of a multiple detector system, such as the LADS, the spectra from individual detectors are combined into a single "composite" spectrum prior to data analysis. In the case of the LADS an appropriately scaled background is subtracted from the composite spectrum as part of the data analysis.

\section{Deep Discovery}

The LADS is controlled by the Deep Discovery Software, which manages all detector functions including stabilization, calibration, and isotope identification. As well as manual and Batch mode control, the system can be configured to automatically identify sources that register above the background count rate. This configuration is called Automatic Acquisition Mode and a representative screen can be seen in Figure C.2.

During the acquisition displayed in Figure C.2, ${ }^{22} \mathrm{Na}$ source was introduced to the environment, generating an increase in the observed signal strength. The result of the isotope identification, for the highlighted area, is given in the isotope-identified table above the signal strength graph. For the purpose of data collection the software is operated in "Batch" mode, which allows multiple data sets to be collected without the need for user input. For the PNNL testing, the unit was used in batch mode. 


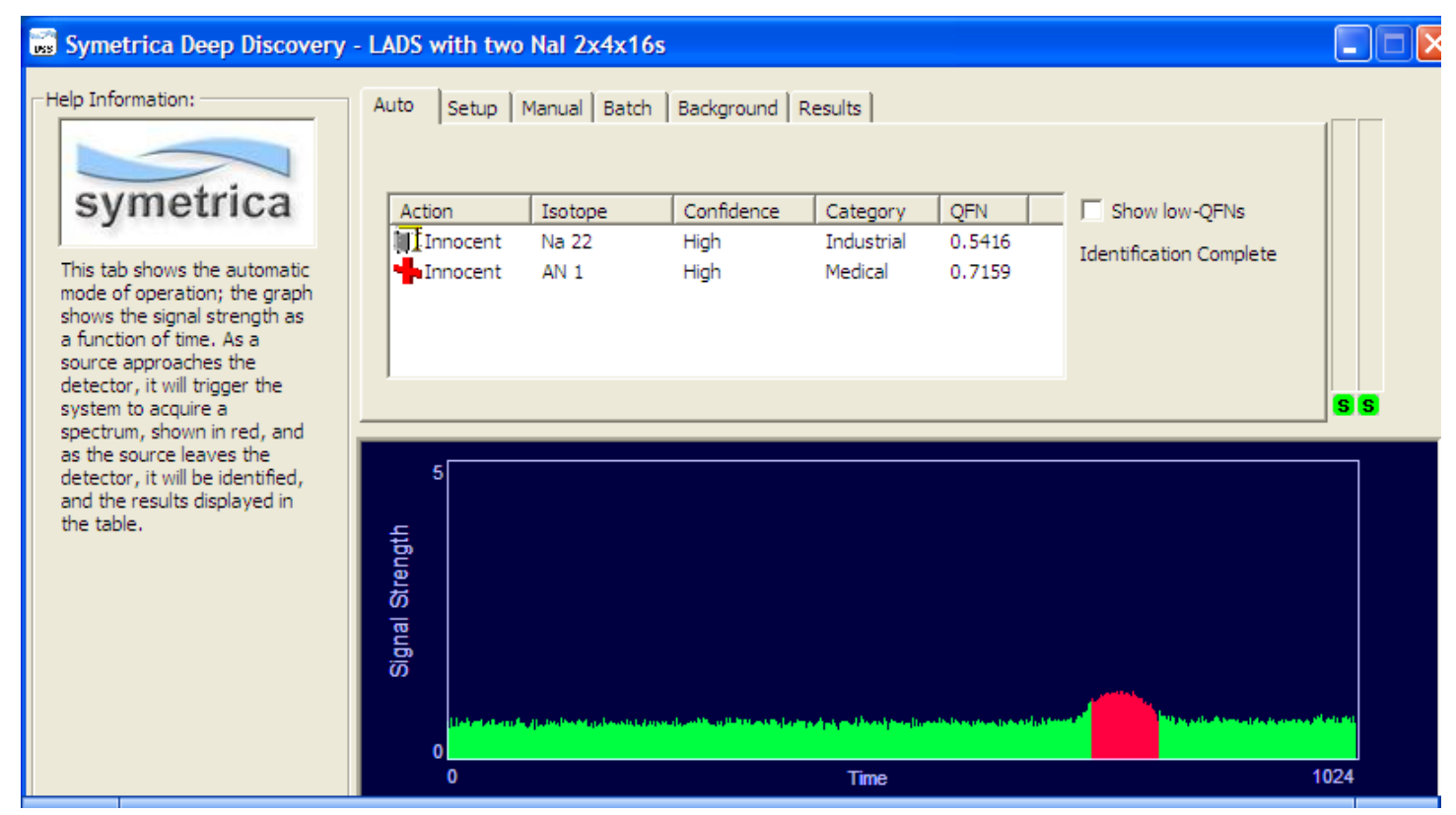

Figure C.2. Screen Shot of Symetrica Deep Discovery Software in Automatic Acquisition Mode

\section{C.4 Analysis of data collected}

Of the 490 data files collected at PNNL, there are some general comments:

- A small number failed to generate an identification due to a software issue.

- The resolution of the replacement detectors used was considerably worse than the configuration in the identification algorithm, resulting in some misidentifications.

Both of these issues were addressed through the re-analysis of the data collected. The reanalyzed results are presented in the following tables. It should be noted that the only modification to the data analysis was to include the correct detector resolution. Our experience with the analysis is that the algorithms are extremely robust to different detector resolutions, as demonstrated during the manufacture, and operational deployment of the SMITHS detection HPRID, which uses the same isotope identification principals, where an energy resolution window of $+/-0.5 \%$ is acceptable. However the energy resolution of the loaned detectors were so far from that of the original units that the software had to be adjusted. The adjustment for detector resolution was the only modification made, for the re-analysis. The SNM sources used in the data collection can be seen in Table C.1. Descriptions of the SNM, industrial and NORM sources can be found in Section 3.

The dose rates measured are presented in Table C. 1 was collected using a $\mu \mathrm{R}$ meter provided by PNNL; the background dose in the laboratory was observed to be $9 \mu \mathrm{R} / \mathrm{hr}$. In the following analysis, simple attenuation is used to determine the full energy peak attenuation. Even though the full energy peaks are attenuated, the down-scattered photons remain and are included in the analysis performed of the complete spectrum. 
Table C.1. Source Details

\begin{tabular}{lcr}
\hline \multicolumn{1}{c}{ Source } & Mass $(\mathrm{g})$ & Net Dose in uR/hr @ 50cm \\
\hline WGPu & $98 \mathrm{~g}$ & 200 \\
$\mathrm{RGPu}$ & $98 \mathrm{~g}$ & 420 \\
$\mathrm{DU}$ & $145 \mathrm{~g}$ & 23 \\
$\mathrm{HEU}$ & $125 \mathrm{~g}$ & 9 \\
\hline
\end{tabular}

\section{C.5 WGPu}

\section{Shielding}

The WGPu sample was placed at a distance of $1 \mathrm{~m}$ from the detector case and was shielded by a number of different materials with varying thicknesses. The results of the identifications are summarized in Table C.2. The attenuation level was calculated from a simple attenuation calculation using the coefficients from NIST XCOM. From Table C.2, it is seen that the limit of full-energy peak attenuation of the source signal for identifying ${ }^{239} \mathrm{Pu}$ is between 90 and $96 \%$.

Table C.2. Summary of Identifications with WGPu with Varying Shielding

\begin{tabular}{|c|c|c|c|c|c|}
\hline \multirow[b]{2}{*}{$\begin{array}{c}\text { Attenuation Level @ } \\
\text { 414keV }\end{array}$} & \multirow{2}{*}{$\begin{array}{c}\text { As recorded } \\
\text { Pu239 Identified }\end{array}$} & \multirow{2}{*}{$\begin{array}{c}\text { Reanalyzed } \\
\text { Pu239 Identified }\end{array}$} & \multicolumn{3}{|c|}{ Shielding materials } \\
\hline & & & Steel (mm) & $\begin{array}{c}\text { Copper } \\
(\mathrm{mm})\end{array}$ & $\begin{array}{r}\text { Lead } \\
(\mathrm{mm})\end{array}$ \\
\hline $37 \%$ & $7 / 10$ & $10 / 10$ & 6.35 & & \\
\hline $75 \%$ & $9 / 10$ & $10 / 10$ & 19.05 & & \\
\hline $90 \%$ & $8 / 10$ & $10 / 10$ & 19.05 & 6.35 & \\
\hline $96 \%$ & $5 / 10$ & $7 / 10$ & 19.05 & 6.35 & 3.175 \\
\hline $100 \%$ & $0 / 10$ & $1 / 10$ & & & 50.8 \\
\hline
\end{tabular}

\section{Distance}

The WGPu sample was placed at a range of distances to determine the sensitivity range of the single module LADS. It should be pointed out that the WGPu was housed in a steel container $1 / 4$ " thick. The results can be seen in Table C.3. From Table C. 3 can be seen that the limiting distance of sensitivity for the sample tested was in excess of $5.3 \mathrm{~m}$.

Table C.3. Summary of Identifications with WGPu at Varying Distance

\begin{tabular}{llll}
\hline & $\begin{array}{c}\text { Extrapolated dose at } \\
\text { detector }(\mu \mathrm{R} / \mathrm{hr})\end{array}$ & $\begin{array}{c}\text { Pu239 Identified } \\
\text { (original) }\end{array}$ & $\begin{array}{c}\text { Pu239 Identified } \\
\text { (Re-analyzed) }\end{array}$ \\
\hline 100 & 75 & $9 / 10$ & $10 / 10$ \\
300 & 8.3 & $10 / 10$ & $10 / 10$ \\
420 & 4.3 & $8 / 10$ & $8 / 10$ \\
530 & 5.6 & $8 / 10$ & $9 / 10$ \\
\hline
\end{tabular}




\section{C.6 RGPu}

Measurements of the RGPu sample were performed using a range of shielding materials. A summary of the results can be seen in Table C.4. From Table C.4 it can be seen that a lower limit of acceptable full-energy peak attenuation for RGPu can be set at $90 \%$.

Table C.4. RGPu Results

\begin{tabular}{lllclc}
\hline & As recorded & Reanalyzed & \multicolumn{3}{c}{ Shielding materials } \\
$\begin{array}{c}\text { Attenuation Level @ } \\
\text { 414keV }\end{array}$ & $\begin{array}{c}\text { Pu239 } \\
\text { Identified }\end{array}$ & $\begin{array}{c}\text { Pu239 } \\
\text { Identified }\end{array}$ & $\begin{array}{c}\text { Steel } \\
(\mathrm{mm})\end{array}$ & $\begin{array}{c}\text { Copper } \\
(\mathrm{mm})\end{array}$ & $\begin{array}{c}\text { Lead } \\
(\mathrm{mm})\end{array}$ \\
\hline $37 \%$ & $5 / 10$ & $10 / 00$ & 6.35 & & \\
$75 \%$ & $11 / 15$ & $12 / 15$ & 19.05 & \\
$90 \%$ & $3 / 5$ & $5 / 5$ & 19.05 & 6.35 \\
\hline
\end{tabular}

\section{C.7 DU}

The WGPu sample was placed at two distances from the LADS. A summary of the results can be seen in Table C.5. In the original results the depleted uranium sample was identified at $50 \mathrm{~cm}$ from the unit on 8 out of 10 occasions but on reanalysis there was a slight degradation in the result. The U238 identification from these tests was not ideal so spectra were inspected to determine the cause. The $1 \mathrm{MeV}$ line is clear in the spectra but the region around the $766 \mathrm{keV}$ line was not always resolved to a good enough standard to provide correct peak identification. Therefore an isotope library change was implemented to improve detection of U238 as can be seen in Table C.5. Note that the library change did not introduce any additional false positive alarms in the overall results.

Table C.5. Summary of Identifications with DU at Varying Distance

\begin{tabular}{|c|c|c|c|c|}
\hline Distance $(\mathrm{cm})$ & $\begin{array}{c}\text { Extrapolated dose at } \\
\text { detector }(\mu \mathrm{R} / \mathrm{hr})\end{array}$ & $\begin{array}{c}\mathrm{U} 238 \\
\text { Identified }\end{array}$ & $\begin{array}{l}\text { U238 Identified } \\
\text { (reanalyzed) }\end{array}$ & $\begin{array}{c}\text { U238 Identified } \\
\text { (library change and } \\
\text { reanalyzed }\end{array}$ \\
\hline 50 & 23 & $8 / 10$ & $6 / 10$ & $10 / 10$ \\
\hline 100 & 5.75 & $0 / 10$ & $0 / 10$ & $8 / 10$ \\
\hline
\end{tabular}

\section{C.8 HEU}

\section{Shielding}

The HEU sample was placed at a distance of $1 \mathrm{~m}$ and was shielded by a number of different materials with varying thickness. The attenuation level for the key line of ${ }^{235} \mathrm{U}$ has been calculated using the XCOM attenuation coefficients for stainless steel. The results of the identifications are summarized in Table C.6. From Table C.6, the full-energy peak attenuation limit for identification of HEU was not reached during the testing. However a lower limit of $87 \%$ attenuation is clearly achieved. 
Table C.6. Summary of Identifications with HEU with Varying Shielding

\begin{tabular}{llll}
\hline Attenuation Level @ 186keV & U235 Identified & U235 Identified (reanalyzed) & Steel (mm) \\
\hline $16 \%$ & $10 / 10$ & $10 / 10$ & 1.1 \\
$69 \%$ & $10 / 10$ & $10 / 10$ & 7.5 \\
$87 \%$ & $4 / 9$ & $9 / 9$ & 13.8 \\
\hline
\end{tabular}

\section{Distance}

The HEU sample was placed at a range of distances to determine sensitivity range of the single module LADS. The results can be seen in Table C.7. From Table C.7 it can be seen that the limit of sensitivity for the sample tested was greater than $3 \mathrm{~m}$, corresponding to a dose $1 / 30^{\text {th }}$ that of the background level.

Table C.7. Summary of Identifications with HEU at Varying Distance

\begin{tabular}{lccl}
\hline Distance $(\mathrm{cm})$ & $\begin{array}{c}\text { Extrapolated dose at } \\
\text { detector }(\mu \mathrm{R} / \mathrm{hr})\end{array}$ & $\begin{array}{c}\text { U235 } \\
\text { Identified }\end{array}$ & $\begin{array}{c}\text { U235 Identified } \\
\text { (reanalyzed) }\end{array}$ \\
\hline 100 & 2.3 & $10 / 10$ & $10 / 10$ \\
200 & 0.6 & $10 / 10$ & $10 / 10$ \\
300 & 0.3 & $2 / 10$ & $9 / 10$ \\
\hline
\end{tabular}

\section{C.9 Cs137}

\section{Distance}

The Cs137 sample was placed at distances of 200 and $300 \mathrm{~cm}$ from the LADS module. The results can be seen in Table C.8. From Table C.8 it can be seen that, upon reanalysis, the limit of sensitivity for the sample tested was not reached.

TableC.8. Summary of Identifications with Cs137 at Varying Distance

\begin{tabular}{cccc}
\hline & Extrapolated dose at & & Cs137 Identified \\
Distance $(\mathrm{cm})$ & detector $(\mu \mathrm{R} / \mathrm{hr})$ & Cs137 Identified & $10 / 10$ \\
\hline 200 & 1.5 & $9 / 10$ & $10 / 10$ \\
\hline
\end{tabular}

\section{C.10 Co60}

\section{Distance}

The Cs137 sample was placed at distances ranging from 100 to $300 \mathrm{~cm}$ from the LADS module. The results can be seen in Table C.9. From Table C.9 it can be seen that the limit of sensitivity for the sample tested was not reached. 
Table C.9. Summary of Identifications with Co60 at Varying Distance

\begin{tabular}{lcll}
\hline Distance $(\mathrm{cm})$ & $\begin{array}{c}\text { Extrapolated dose at } \\
\text { detector }(\mu \mathrm{R} / \mathrm{hr})\end{array}$ & \multicolumn{1}{c}{ Co60 Identified } & $\begin{array}{c}\text { Co60 Identified } \\
\text { (reanalyzed) }\end{array}$ \\
\hline 100 & 10 & $10 / 10$ & $10 / 10$ \\
200 & 2.5 & $10 / 10$ & $10 / 10$ \\
300 & 1.1 & $9 / 10$ & $10 / 10$ \\
\hline
\end{tabular}

\section{C.11 Co57}

\section{Distance}

The Co57 sample was placed at distances of ranging from 50 to $200 \mathrm{~cm}$ from the LADS module. The results can be seen in Table C.10. From Table C.10 it can be seen that there is a significant improvement with reanalysis. The limit of sensitivity for the sample tested is between 100 and $200 \mathrm{~cm}$. At $200 \mathrm{~cm}$ the main Co57 peak in the spectra is still clear, but currently a threshold on the intensity of the Co57 source prevents detection at $200 \mathrm{~cm}$.

Table C.10. Summary of Identifications with Co57 at Varying Distance

\begin{tabular}{lcll}
\hline Distance $(\mathrm{cm})$ & $\begin{array}{c}\text { Extrapolated dose at } \\
\text { detector }(\mu \mathrm{R} / \mathrm{hr})\end{array}$ & Co57 Identified & $\begin{array}{c}\text { Co57 Identified } \\
\text { (reanalyzed) }\end{array}$ \\
\hline 50 & 0.5 & $5 / 10$ & $10 / 10$ \\
100 & 0.1 & $0 / 10$ & $9 / 10$ \\
200 & 0.03 & $0 / 10$ & $0 / 10$ \\
\hline
\end{tabular}

\section{C.12 Ba133}

The Ba133 sample was placed at a distance of $100 \mathrm{~cm}$ from the LADS module. At this distance an extrapolated dose of $2.8 \mu \mathrm{R} / \mathrm{hr}$ was calculated. Spectra were obtained using acquisition times ranging from 5 to $300 \mathrm{~s}$. In total Ba133 was identified in 12/17 acquisitions but with reanalysis Ba133 is identified in $100 \%$ of the acquisitions. The Ba133 in the sample used could be identified from acquisitions with a maximum lower integration time limit of $5 \mathrm{~s}$.

\section{C.13 NORM Sources}

The NORM samples were in general placed in contact with the LADS module with the exception of the Zircon Sand source that was placed at two different distances. The results can be seen in Table C.11. In general the isotopes identified were as expected with only a few unexpected identifications of other isotopes. Ra226 was identified successfully from the Zircon sand sample and K40 was identified successfully from the Ice Melt and Fertilizer, however, Th232 identifications were not as frequent as might be expected for the Kitty Litter, Tiles and Granite. The K40 isotope is still the dominant isotope present in these spectra. 
Note that in the Lanthanum carbonate test the stabilization of the system was lost for the duration of this test and the spectra needed recalibrating. The results shown are those obtained with the newly calibrated spectra.

TableC.11. Summary of Identifications with NORM Sources

\begin{tabular}{lcl}
\hline \multicolumn{1}{c}{ Source } & Distance $(\mathrm{cm})$ & $\begin{array}{c}\text { Isotopes Identified } \\
\text { (reanalyzed) }\end{array}$ \\
\hline Zircon Sand & 100 & Ra226 5/6 \\
& & Th232 $2 / 6$ \\
& & K40 $1 / 6$ \\
& & U232 $1 / 6$ \\
& & Co57 $1 / 6$ \\
& & Cr51 $1 / 6$ \\
Zircon Sand & & Pu239 $1 / 6$ \\
& & Ra226 9/10 \\
& & Th232 4/10 \\
Ice Melt & & U232 4/10 \\
Kitty Litter & & K40 $10 / 10$ \\
Tiles & Contact & K40 5/10 \\
& Contact & Th232 5/10 \\
Fertilizer & K40 8/10 \\
Granite & Th232 5/10 & U233 $1 / 10$ \\
Lanthanum & & K40 10/10 \\
Carbonate & K40 8/10 \\
\hline
\end{tabular}

\section{C.14 Natural Uranium Sources}

A few tests were done with the Yellowcake and Heisenberg cube samples. The samples were placed at either 50 or $100 \mathrm{~cm}$ from with the LADS module. A test with the Yellowcake sample shielded by steel was also taken. The results of these tests are summarized in Table C.12. A similar issue to that seen with DU occurs with the identification of U238 in these tests and therefore the same library change was implemented. With this library change U238 is identified $100 \%$ of the time. The exception to this is the test with the Heisenberg cube placed at $100 \mathrm{~cm}$ from the LADS module. In this instance an intensity threshold prevents U238 identification $100 \%$ of the time. 
TableC.12. Summary of Identifications with Natural Uranium Sources

\begin{tabular}{|c|c|c|c|c|c|}
\hline Source & Distance $(\mathrm{cm})$ & Shielding & $\begin{array}{c}\mathrm{U} 238 \\
\text { Identified } \\
\end{array}$ & $\begin{array}{l}\text { U238 Identified } \\
\text { (reanalyzed) }\end{array}$ & $\begin{array}{c}\text { U238 Identified } \\
\text { (library change and } \\
\text { reanalyzed) }\end{array}$ \\
\hline Yellowcake & 50 & None & $4 / 25$ & $19 / 25$ & $25 / 25$ \\
\hline Yellowcake & 50 & $6.35 \mathrm{~mm}$ Steel Plate & $0 / 10$ & $2 / 10$ & $10 / 10$ \\
\hline $\begin{array}{l}\text { Heisenberg } \\
\text { Cube }\end{array}$ & 50 & None & $11 / 20$ & $20 / 20$ & $20 / 20$ \\
\hline $\begin{array}{l}\text { Heisenberg } \\
\text { Cube }\end{array}$ & 100 & None & $0 / 10$ & $0 / 10$ & $7 / 10$ \\
\hline
\end{tabular}

\section{C.15 Summary of Results}

The results from the Symetrica identification routine used to reanalyze the LADS data are summarized in Table C.13. Note that the results are those obtained from reanalysis with the U238 library change incorporated and recalibration of the Lanthanum Carbonate test spectra.

Table C.13. Summary of Source Identifications From Symetrica

\begin{tabular}{|c|c|c|c|}
\hline Source & $\begin{array}{c}\text { Batch Results: } \\
\text { Source ID at }>=80 \% / \text { Runs }\end{array}$ & $\begin{array}{c}\text { Source Isotopes at }>=80 \% \\
\text { identification level }\end{array}$ & $\begin{array}{c}\text { Other Isotopes at }>=80 \% \\
\text { identification level }\end{array}$ \\
\hline Cs-137 & $4 / 4$ & Cs137 & \\
\hline Co-57 & $4 / 6$ & (Co57 19/30) & \\
\hline Co-60 & $6 / 6$ & Co60 & \\
\hline Ba-133 & $1 / 1$ & Ba133 & \\
\hline Zirc Sand & $2 / 2$ & $\mathrm{Ra} 226$ & \\
\hline Ice Melt & $1 / 1$ & K40 & \\
\hline Kitty Litter & $0 / 1$ & (K40 5/10, Th232 5/10) & \\
\hline Tiles & $1 / 1$ & K40 & \\
\hline Fertilizer & $1 / 1$ & K40 & \\
\hline Granite & $1 / 1$ & K40 & \\
\hline Lanthanum Carbonate & $1 / 1$ & La138 & \\
\hline WGPu & $7 / 8$ & $\mathrm{Pu} 239$ & \\
\hline WGPu (shielded) & $6 / 9$ & (Pu239 32/45) & (I123 29/45) \\
\hline \multirow[t]{3}{*}{$\mathrm{RGPu}$} & $6 / 6$ & Am241 & Sm153 \\
\hline & & $\mathrm{Pu} 241$ & \\
\hline & & Pu239 & \\
\hline \multirow[t]{3}{*}{ RGPu (shielded) } & $5 / 6$ & $\mathrm{Pu} 241$ & Cs137 \\
\hline & & Am241 & \\
\hline & & Pu239 & \\
\hline HEU & $12 / 13$ & $\mathrm{U} 235$ & \\
\hline DU & $3 / 4$ & U238 & \\
\hline Yellowcake & $5 / 5$ & $\mathrm{U} 238$ & \\
\hline Heisenberg Cube & $4 / 5$ & $\mathrm{U} 238$ & \\
\hline
\end{tabular}



Appendix D

GADRAS Results

D. 1 



\section{Appendix D GADRAS Results}

Table D.1. Complete GADRAS Results

\begin{tabular}{|c|c|c|c|c|c|c|c|c|}
\hline Date & $\begin{array}{l}\text { Batch } \\
\text { Number }\end{array}$ & Source & $\begin{array}{l}\text { Live } \\
\text { time } \\
\text { (sec) }\end{array}$ & $\begin{array}{c}\text { Net } \\
\text { Gamma } \\
\text { (cps) }\end{array}$ & SNM Prob. & Threat: & Chi-square: & Isotopes: \\
\hline 3-Nov-2008 & Batch002 & WGPu $100 \mathrm{~g}$ & 18.84 & 4427 & 3 (High) & $7(\mathrm{SNM}=\mathrm{H})$ & 0.94 & Pu239(H,201g); U328(F,274g) \\
\hline 3-Nov-2008 & Batch003 & WGPu $100 \mathrm{~g}$ & 19.12 & 4259 & 3 (High) & $7(\mathrm{SNM}=\mathrm{H})$ & 0.91 & Pu239(H,183g); U238(F,605g) \\
\hline 3-Nov-2008 & Batch004 & WGPu $100 \mathrm{~g}$ & 19.2 & 4073 & 3 (High) & $7(\mathrm{SNM}=\mathrm{H})$ & 0.90 & Pu239(H,167g); U238(F,349g) \\
\hline 3-Nov-2008 & Batch005 & WGPu $100 \mathrm{~g}$ & 19.04 & 4148 & 3 (High) & $7(\mathrm{SNM}=\mathrm{H})$ & 0.89 & Pu239(H,163g); U238(F,118g) \\
\hline 3-Nov-2008 & Batch006 & WGPu $100 \mathrm{~g}$ & 19.26 & 2246 & 3 (High) & $7(\mathrm{SNM}=\mathrm{H})$ & 0.97 & Pu239(H,100g) \\
\hline 3-Nov-2008 & Batch007 & WGPu $100 \mathrm{~g}$ & 19.22 & 2266 & 3 (High) & $7(\mathrm{SNM}=\mathrm{H})$ & 1.04 & Pu239(H,156g) \\
\hline 3-Nov-2008 & Batch008 & WGPu $100 \mathrm{~g}$ & 19.48 & 1475 & 3 (High) & $7(\mathrm{SNM}=\mathrm{H})$ & 1.00 & Pu239(H,114g) \\
\hline 3-Nov-2008 & Batch009 & WGPu $100 \mathrm{~g}$ & 19.44 & 1504 & 3 (High) & $7(\mathrm{SNM}=\mathrm{H})$ & 0.78 & Pu239(H,64g); U238(H,329g) \\
\hline 3-Nov-2008 & Batch011 & RGPu 98g & 18.06 & 13846 & 3 (High) & 7 (SNM=H) & 3.19 & $\begin{array}{l}\text { Am241(H,2Ci); Pu239(H,18g); } \\
\text { U237(H32uCi); Th228(F,1uCi); } \\
\text { U238(F,212g) }\end{array}$ \\
\hline 3-Nov-2008 & Batch012 & RGPu 98g & 18.4 & 13604 & 3 (High) & $7(\mathrm{SNM}=\mathrm{H})$ & 2.44 & $\begin{array}{l}\text { Am241(H,2Ci); Pu239(H,735g); } \\
\text { U237(H,43uCi); U238(F,213g); } \\
\text { Th228(F,1uCi) }\end{array}$ \\
\hline 3-Nov-2008 & Batch013 & RGPu 98g & 18.68 & 7518 & 3 (High) & $7(\mathrm{SNM}=\mathrm{H})$ & 2.11 & $\begin{array}{l}\text { Am241(H,992mCi); Pu239(H,378g); } \\
\text { U237(H,17uCi); U238(F,206g) }\end{array}$ \\
\hline 3-Nov-2008 & Batch014 & RGPu 98g & 18.74 & 7437 & 3 (High) & $7(\mathrm{SNM}=\mathrm{H})$ & 2.09 & $\begin{array}{l}\text { Pu239(H,409g); Am241(H,975mCi); } \\
\text { U237(H,24uCi); U238(F,230g); } \\
\text { Co57(F,6uCi) }\end{array}$ \\
\hline 3-Nov-2008 & Batch015 & RGPu 98g & 19.02 & 4867 & 3 (High) & $7(\mathrm{SNM}=\mathrm{H})$ & 1.36 & $\begin{array}{l}\text { Am241(H,586mCi); Pu239(H,293g); } \\
\text { U237(H,10uCi); U238(F,174g); } \\
\text { U235(F,336g) }\end{array}$ \\
\hline 3-Nov-2008 & Batch016 & RGPu 98g & 18.76 & 4942 & 3 (High) & $7(\mathrm{SNM}=\mathrm{H})$ & 1.31 & $\begin{array}{l}\text { Am241(H,597mCi); Pu239(H,317g); } \\
\text { U237(H,10uCi); U238(H,173g); } \\
\text { U235(L,317g) }\end{array}$ \\
\hline 4-Nov-2008 & Batch017 & cs137 & 19.32 & 309 & 0 (Very Low) & 3 (Industrial) & 0.50 & $\mathrm{Cs} 137(\mathrm{H}, 205 \mathrm{mCi})$ \\
\hline 4-Nov-2008 & Batch018 & cs137 & 19.72 & 292 & 0 (Very Low) & 3 (Industrial) & 0.72 & $\mathrm{Cs} 137(\mathrm{H}, 162 \mathrm{mCi})$ \\
\hline 4-Nov-2008 & Batch019 & cs137 & 19.56 & 173 & 0 (Very Low) & 3 (Industrial) & 0.46 & $\mathrm{Cs} 137(\mathrm{H}, 115 \mathrm{mCi})$ \\
\hline 4-Nov-2008 & Batch020 & cs137 & 19.7 & 196 & 0 (Very Low) & 3 (Industrial) & 0.54 & $\mathrm{Cs} 137(\mathrm{H}, 45 \mathrm{mCi})$ \\
\hline 4-Nov-2008 & Batch021 & Co60 & 19.28 & 1183 & 0 (Very Low) & 3 (Industrial) & 1.14 & $\mathrm{Co60}(\mathrm{H}, 19 \mathrm{uCi})$ \\
\hline 4-Nov-2008 & Batch022 & Co60 & 19.44 & 1160 & 0 (Very Low) & 3 (Industrial) & 0.98 & $\begin{array}{l}\text { Co60(H,6uCi); Lu177m(F,1uCi); } \\
\text { Na22(F,1uCi) }\end{array}$ \\
\hline 4-Nov-2008 & Batch023 & Co60 & 19.28 & 444 & 0 (Very Low) & 3 (Industrial) & 0.69 & $\mathrm{Co60}(\mathrm{H}, 5 \mathrm{uCi})$ \\
\hline 4-Nov-2008 & Batch024 & Co60 & 19.44 & 454 & 0 (Very Low) & 3 (Industrial) & 0.65 & $\mathrm{Co60}(\mathrm{H}, 2 \mathrm{uCi}) ; \mathrm{Na} 22(\mathrm{~F}, 1 \mathrm{uCi})$ \\
\hline 4-Nov-2008 & Batch025 & Co60 & 19.04 & 271 & 0 (Very Low) & 3 (Industrial) & 0.61 & $\mathrm{Co60}(\mathrm{H}, 1 \mathrm{uCi})$ \\
\hline 4-Nov-2008 & Batch026 & Co60 & 19.26 & 283 & 0 (Very Low) & 3 (Industrial) & 0.62 & $\mathrm{Co60}(\mathrm{H}, 1 \mathrm{uCi})$ \\
\hline 4-Nov-2008 & Batch027 & DU & 19.3 & 1188 & 2 (Fair) & $6(\mathrm{SNM}=\mathrm{F})$ & 0.46 & $\mathrm{U} 238(\mathrm{H}, 3 \mathrm{~kg})$ \\
\hline 4-Nov-2008 & Batch028 & DU & 19.36 & 1201 & 2 (Fair) & $6(\mathrm{SNM}=\mathrm{F})$ & 0.64 & $\mathrm{U} 238(\mathrm{H}, 3 \mathrm{~kg})$ \\
\hline 4-Nov-2008 & Batch029 & DU & 19.2 & 2781 & 2 (Fair) & $6(\mathrm{SNM}=\mathrm{F})$ & 0.66 & $\mathrm{U} 238(\mathrm{H}, 52 \mathrm{~kg})$ \\
\hline
\end{tabular}


Table D.1. (contd)

\begin{tabular}{|c|c|c|c|c|c|c|c|c|}
\hline Date & $\begin{array}{c}\text { Batch } \\
\text { Number }\end{array}$ & Source & $\begin{array}{l}\text { Live } \\
\text { time } \\
\text { (sec) } \\
\end{array}$ & $\begin{array}{c}\text { Net } \\
\text { Gamma } \\
\text { (cps) }\end{array}$ & SNM Prob. & Threat: & Chi-square: & Isotopes: \\
\hline 4-Nov-2008 & Batch030 & DU & 19 & 2773 & 2 (Fair) & $6(\mathrm{SNM}=\mathrm{F})$ & 0.74 & $\mathrm{U} 238(\mathrm{H}, 8 \mathrm{~kg})$ \\
\hline 4-Nov-2008 & Batch031 & $\operatorname{co5} 7$ & 18.84 & 339 & 0 (Very Low) & 3 (Industrial) & 0.60 & $\operatorname{Co57}(\mathrm{H}, 1 \mathrm{uCi})$ \\
\hline 4-Nov-2008 & Batch032 & $\operatorname{co5} 7$ & 19.7 & 323 & 0 (Very Low) & 3 (Industrial) & 0.63 & $\operatorname{Co57}(\mathrm{H}, 1 \mathrm{uCi})$ \\
\hline 4-Nov-2008 & Batch033 & $\operatorname{co5} 5$ & 18.84 & 160 & 0 (Very Low) & 3 (Industrial) & 0.42 & $\mathrm{Co} 57(\mathrm{H}, 1 \mathrm{uCi}) ; \mathrm{Na} 22(\mathrm{~F}, 1 \mathrm{uCi})$ \\
\hline 4-Nov-2008 & Batch034 & $\operatorname{co5} 5$ & 19.62 & 134 & 0 (Very Low) & 3 (Industrial) & 0.44 & $\mathrm{Co57}(\mathrm{H}, 1 \mathrm{uCi})$ \\
\hline 4-Nov-2008 & Batch035 & $\operatorname{co5} 5$ & 19.54 & 257 & 0 (Very Low) & 3 (Industrial) & 0.49 & $\mathrm{Co57}(\mathrm{H}, 1 \mathrm{uCi})$ \\
\hline 4-Nov-2008 & Batch036 & $\operatorname{co5} 5$ & 20.06 & 224 & 0 (Very Low) & 3 (Industrial) & 0.51 & $\mathrm{Co57}(\mathrm{H}, 1 \mathrm{uCi})$ \\
\hline 4-Nov-2008 & Batch037 & Ba133 & 19.36 & 1055 & 0 (Very Low) & 3 (Industrial) & 0.72 & $\mathrm{Ba} 133(\mathrm{H}, 19 \mathrm{uCi}) ; \mathrm{Cf} 252(\mathrm{~F}, 1 \mathrm{uCi})$ \\
\hline 4-Nov-2008 & Batch038 & Zirc Sand & 29.42 & 1860 & 0 (Very Low) & 3 (Suspect) & 0.64 & $\begin{array}{l}\text { Ra226(H,9uCi); Th232(H,2uCi); } \\
\text { U238(F,28kg) }\end{array}$ \\
\hline 4-Nov-2008 & Batch039 & Zirc Sand & 28.26 & 8111 & 2 (Fair) & $6(\mathrm{SNM}=\mathrm{F})$ & 1.60 & $\begin{array}{l}\text { Ra226(H,38uCi); Th232(H,21uCi); } \\
\text { U238(F,179kg) }\end{array}$ \\
\hline 4-Nov-2008 & Batch040 & Ice Melt & 29.22 & 4614 & 0 (Very Low) & $\begin{array}{l}4 \text { (High } \\
\text { Gamma) }\end{array}$ & 2.12 & K40(H,91uCi); Th232(H,8uCi) \\
\hline 4-Nov-2008 & Batch041 & Kitty Litter & 29.5 & 734 & 2 (Fair) & $6(\mathrm{SNM}=\mathrm{F})$ & 0.52 & $\begin{array}{l}\mathrm{K} 40(\mathrm{H}, 2 \mathrm{uCi}) ; \mathrm{Th} 232(\mathrm{H}, 2 \mathrm{uCi}) ; \\
\mathrm{U} 232(\mathrm{~F}, 520 \mathrm{~g})\end{array}$ \\
\hline 4-Nov-2008 & Batch042 & Tiles & 29.42 & 868 & 0 (Very Low) & 1 (Natural) & 1.98 & $\mathrm{~K} 40(\mathrm{H}, 4 \mathrm{uCi}) ; \mathrm{Th} 232(\mathrm{H}, 1 \mathrm{uCi})$ \\
\hline 4-Nov-2008 & Batch043 & Fertilizer & 29.06 & 3529 & 0 (Very Low) & $\begin{array}{l}4 \text { (High } \\
\text { Gamma) }\end{array}$ & 4.38 & K40(H,46uCi); Th232(H,6uCi) \\
\hline 4-Nov-2008 & Batch044 & Granite & 29.98 & 585 & 0 (Very Low) & 1 (Natural) & 1.65 & $\mathrm{~K} 40(\mathrm{H}, 4 \mathrm{uCi}) ; \mathrm{Th} 232(\mathrm{H}, 4 \mathrm{uCi})$ \\
\hline 4-Nov-2008 & Batch045 & $\begin{array}{l}\text { Lanthanum } \\
\text { Carbonate }\end{array}$ & 29.76 & 440 & 0 (Very Low) & 4 (Bad ID) & 3.27 & $\begin{array}{l}\text { K40(H,27uCi); Ho166m(F,2uCi); } \\
\text { Mn54(F,1uCi) }\end{array}$ \\
\hline 5-Nov-2008 & Batch046 & HEU & 19.56 & 2154 & 3 (High) & $7(\mathrm{SNM}=\mathrm{H})$ & 0.59 & $\mathrm{U} 235(\mathrm{H}, 624 \mathrm{~g})$ \\
\hline 5-Nov-2008 & Batch047 & HEU & 19.56 & 2182 & 3 (High) & $7(\mathrm{SNM}=\mathrm{H})$ & 0.62 & $\mathrm{U} 235(\mathrm{H}, 594 \mathrm{~g})$ \\
\hline 5-Nov-2008 & Batch048 & HEU & 19.14 & 773 & 3 (High) & $7(\mathrm{SNM}=\mathrm{H})$ & 0.60 & $\mathrm{U} 235(\mathrm{H}, 257 \mathrm{~g})$ \\
\hline 5-Nov-2008 & Batch049 & HEU & 19.74 & 749 & 3 (High) & $7(\mathrm{SNM}=\mathrm{H})$ & 0.51 & $\mathrm{U} 235(\mathrm{H}, 242 \mathrm{~g})$ \\
\hline 5-Nov-2008 & Batch050 & HEU & 19.52 & 349 & 3 (High) & $7(\mathrm{SNM}=\mathrm{H})$ & 0.43 & $\mathrm{U} 235(\mathrm{H}, 108 \mathrm{~g})$ \\
\hline 5-Nov-2008 & Batch051 & HEU & 19.24 & 371 & 3 (High) & $7(\mathrm{SNM}=\mathrm{H})$ & 0.62 & $\mathrm{U} 235(\mathrm{H}, 126 \mathrm{~g})$ \\
\hline 5-Nov-2008 & Batch052 & HEU & 19.34 & 222 & 3 (High) & $7(\mathrm{SNM}=\mathrm{H})$ & 0.46 & $\mathrm{U} 235(\mathrm{H}, 69 \mathrm{~g})$ \\
\hline 5-Nov-2008 & Batch053 & HEU & 19.64 & 1787 & 3 (High) & $7(\mathrm{SNM}=\mathrm{H})$ & 0.65 & $\mathrm{U} 235(\mathrm{H}, 657 \mathrm{~g})$ \\
\hline 5-Nov-2008 & Batch054 & HEU & 19.26 & 1777 & 3 (High) & $7(\mathrm{SNM}=\mathrm{H})$ & 0.56 & $\mathrm{U} 235(\mathrm{H}, 899 \mathrm{~g}) ; \mathrm{U} 238(\mathrm{~F}, 73 \mathrm{~g})$ \\
\hline 5-Nov-2008 & Batch055 & HEU & 19.4 & 963 & 3 (High) & $7(\mathrm{SNM}=\mathrm{H})$ & 0.49 & $\mathrm{U} 235(\mathrm{H}, 493 \mathrm{~g})$ \\
\hline 5-Nov-2008 & Batch056 & HEU & 19.42 & 927 & 3 (High) & $7(\mathrm{SNM}=\mathrm{H})$ & 0.48 & $\mathrm{U} 235(\mathrm{H}, 510 \mathrm{~g})$ \\
\hline 5-Nov-2008 & Batch057 & HEU & 19.58 & 613 & 3 (High) & $7(\mathrm{SNM}=\mathrm{H})$ & 0.54 & $\mathrm{U} 235(\mathrm{H}, 317 \mathrm{~g})$ \\
\hline 5-Nov-2008 & Batch058 & HEU & 19.38 & 625 & 3 (High) & $7(\mathrm{SNM}=\mathrm{H})$ & 0.46 & $\mathrm{U} 235(\mathrm{H}, 320 \mathrm{~g})$ \\
\hline 5-Nov-2008 & Batch059 & HEU & \multicolumn{6}{|c|}{ empty data file } \\
\hline 5-Nov-2008 & Batch060 & Unlabeled & 17.5 & 18356 & 3 (High) & $7(\mathrm{SNM}=\mathrm{H})$ & 1.45 & Pu239(H,2kg); U238(F,50kg) \\
\hline 5-Nov-2008 & Batch061 & WGPu & \multicolumn{6}{|c|}{ empty data file } \\
\hline 5-Nov-2008 & Batch062 & WGPu & 17.74 & 18368 & 3 (High) & $7(\mathrm{SNM}=\mathrm{H})$ & 0.81 & $\begin{array}{l}\text { Pu239(H,768g); Am241(H753mCi) } \\
\text { TI201(F,44uCi) }\end{array}$ \\
\hline 5-Nov-2008 & Batch063 & WGPu & 18.62 & 9952 & 3 (High) & $7(\mathrm{SNM}=\mathrm{H})$ & 0.82 & $\begin{array}{l}\text { Pu239(H,665g); Cs137(F,37mCi); } \\
\text { Ba133(F,6uCi) }\end{array}$ \\
\hline
\end{tabular}


Table D.1. (contd)

\begin{tabular}{|c|c|c|c|c|c|c|c|c|}
\hline Date & $\begin{array}{c}\text { Batch } \\
\text { Number }\end{array}$ & Source & $\begin{array}{l}\text { Live } \\
\text { time } \\
\text { (sec) }\end{array}$ & $\begin{array}{c}\text { Net } \\
\text { Gamma } \\
\text { (cps) }\end{array}$ & SNM Prob. & Threat: & Chi-square: & Isotopes: \\
\hline 5-Nov-2008 & Batch064 & WGPu & 18.76 & 10013 & 3 (High) & $7(\mathrm{SNM}=\mathrm{H})$ & 1.50 & Pu239(H,561g) \\
\hline 5-Nov-2008 & Batch065 & WGPu & 18.78 & 7412 & 3 (High) & $7(\mathrm{SNM}=\mathrm{H})$ & 0.77 & Pu239(H,2kg); U235(F,447g) \\
\hline 5-Nov-2008 & Batch066 & WGPu & 18.6 & 7065 & 3 (High) & $7(\mathrm{SNM}=\mathrm{H})$ & 0.83 & Pu239(H,966g); U235(F,447g) \\
\hline 5-Nov-2008 & Batch067 & WGPu & 19.06 & 5133 & 3 (High) & $7(\mathrm{SNM}=\mathrm{H})$ & 0.72 & $\begin{array}{l}\text { Pu239(H,989g); U235(H,462g); } \\
\text { U238(F,1kg) }\end{array}$ \\
\hline 5-Nov-2008 & Batch068 & WGPu & 18.98 & 5008 & 3 (High) & $7(\mathrm{SNM}=\mathrm{H})$ & 0.77 & Pu239(H,996g); U235(F,426g) \\
\hline 5-Nov-2008 & Batch069 & WGPu & 19.54 & 3239 & 3 (High) & $7(\mathrm{SNM}=\mathrm{H})$ & 1.19 & $\begin{array}{l}\text { Np237(H,21g); In111(H,4uCi); } \\
\text { Tl201(H,601uCi); U237(H,6uCi); } \\
\text { U235(F,297g) }\end{array}$ \\
\hline 5-Nov-2008 & Batch070 & WGPu & 19 & 3142 & 3 (High) & $7(\mathrm{SNM}=\mathrm{H})$ & 1.37 & $\begin{array}{l}\text { In111(H,3uCi); Np237(H,21g); } \\
\text { U235(H,375g); I123(H,25uCi); } \\
\text { U237(F,5uCi) }\end{array}$ \\
\hline 5-Nov-2008 & Batch071 & RGPu & 15.34 & 43178 & 3 (High) & $7(\mathrm{SNM}=\mathrm{H})$ & 2.05 & $\begin{array}{l}\text { Am241(H,11Ci); Pu239(H,6kg); } \\
\text { Th232(H,2uCi); U238(H,11kg); } \\
\text { U237(H,2Ci) }\end{array}$ \\
\hline 5-Nov-2008 & Batch072 & RGPu & 15.94 & 42349 & 3 (High) & 7 (SNM=H) & 1.87 & $\begin{array}{l}\text { Am241(H,10Ci); Pu239(H,7kg); } \\
\text { Th232(H,5uCi); U237(H,99uCi); } \\
\text { U238(H,2kg) }\end{array}$ \\
\hline 5-Nov-2008 & Batch073 & RGPu & 15.58 & 43062 & 3 (High) & $7(\mathrm{SNM}=\mathrm{H})$ & 2.29 & $\begin{array}{l}\text { Am241(H,10Ci); Pu239(H,7kg); } \\
\text { Th232(H,5uCi); U237(H,109uCi); } \\
\text { U238(F,5kg) }\end{array}$ \\
\hline 5-Nov-2008 & Batch074 & RGPu & 17.76 & 20167 & 3 (High) & $7(\mathrm{SNM}=\mathrm{H})$ & 2.10 & $\begin{array}{l}\text { Am241(H,4Ci); Pu239(H,1kg); } \\
\text { U235(F,1 kg) }\end{array}$ \\
\hline 5-Nov-2008 & Batch075 & RGPu & 17.62 & 20430 & 3 (High) & $7(\mathrm{SNM}=\mathrm{H})$ & 3.52 & Am241(H,4Ci); Pu239(H,3kg) \\
\hline 5-Nov-2008 & Batch076 & $?$ & empty & file & & & & \\
\hline 5-Nov-2008 & Batch077 & RGPu & 18.02 & 16415 & 3 (High) & $7(\mathrm{SNM}=\mathrm{H})$ & 1.50 & $\begin{array}{l}\text { Pu239(H,2kg); Am241(H,951mCi); } \\
\text { Cs137(H,289mCi); U235(F,744g) }\end{array}$ \\
\hline 5-Nov-2008 & Batch078 & Yellowcake & 17.86 & 16311 & 3 (High) & $7(\mathrm{SNM}=\mathrm{H})$ & 1.32 & $\begin{array}{l}\text { Am241(H,3Ci); Pu239(H,2kg); } \\
\text { U235(H,2kg) }\end{array}$ \\
\hline 5-Nov-2008 & Batch079 & Yellowcake & 19.6 & 1416 & 3 (High) & $7(\mathrm{SNM}=\mathrm{H})$ & 0.51 & $\begin{array}{l}\text { U238(H,14kg); U235(H,38kg); } \\
\text { Pu239(F,65g) }\end{array}$ \\
\hline 5-Nov-2008 & Batch080 & Yellowcake & 19.52 & 1406 & 3 (High) & $7(\mathrm{SNM}=\mathrm{H})$ & 0.71 & $\mathrm{U} 238(\mathrm{H}, 977 \mathrm{~g}) ; \mathrm{U} 235(\mathrm{H}, 40 \mathrm{~g})$ \\
\hline 5-Nov-2008 & Batch081 & Yellowcake & 19.4 & 1403 & 3 (High) & 7 (SNM=H) & 0.58 & $\begin{array}{l}\text { U238(H,908g); Pu239(F,76g); } \\
\text { U235(F,40g) }\end{array}$ \\
\hline 5-Nov-2008 & Batch082 & Heisenberg & 19.48 & 858 & 2 (Fair) & $6(\mathrm{SNM}=\mathrm{F})$ & 0.51 & $\mathrm{U} 238(\mathrm{H}, 768 \mathrm{~g})$ \\
\hline 5-Nov-2008 & Batch083 & Heisenberg & 20 & 822 & 2 (Fair) & $6(\mathrm{SNM}=\mathrm{F})$ & 0.48 & $\mathrm{U} 238(\mathrm{H}, 1 \mathrm{~kg})$ \\
\hline 5-Nov-2008 & Batch084 & Heisenberg & 19.52 & 1952 & 2 (Fair) & $6(\mathrm{SNM}=\mathrm{F})$ & 0.54 & $\mathrm{U} 238(\mathrm{H}, 3 \mathrm{~kg})$ \\
\hline 5-Nov-2008 & Batch085 & Heisenberg & 19.58 & 1948 & 2 (Fair) & $6(\mathrm{SNM}=\mathrm{F})$ & 0.50 & $\mathrm{U} 238(\mathrm{H}, 47 \mathrm{~kg}) ; \mathrm{U} 235(\mathrm{~L}, 32 \mathrm{~g})$ \\
\hline 5-Nov-2008 & Batch086 & Heisenberg & empty & file & & & & \\
\hline 5-Nov-2008 & Batch087 & Heisenberg & 58.28 & 1924 & 2 (Fair) & $6(\mathrm{SNM}=\mathrm{F})$ & 0.51 & $\mathrm{U} 238(\mathrm{H}, 58 \mathrm{~kg}) ; \mathrm{U} 235(\mathrm{~F}, 37 \mathrm{~g})$ \\
\hline 5-Nov-2008 & Batch088 & Yellowcake & 57.68 & 1316 & 3 (High) & 7 (SNM=H) & 0.77 & $\begin{array}{l}\text { U238(H,776g); U235(F,29g); } \\
\text { Pu239(F,18g) }\end{array}$ \\
\hline 5-Nov-2008 & Batch089 & Yellowcake & 58.22 & 983 & 2 (Fair) & $6(\mathrm{SNM}=\mathrm{F})$ & 0.47 & $\mathrm{U} 238(\mathrm{H}, 2 \mathrm{~kg}) ; \mathrm{U} 235(\mathrm{~F}, 21 \mathrm{~g})$ \\
\hline 5-Nov-2008 & Batch090 & Unlabeled & 58.12 & 986 & 2 (Fair) & $6(\mathrm{SNM}=\mathrm{F})$ & 0.45 & $\mathrm{U} 238(\mathrm{H}, 2 \mathrm{~kg}) ; \mathrm{U} 235(\mathrm{~L}, 22 \mathrm{~g})$ \\
\hline
\end{tabular}


Table D.2. Complete SNM data runs using GADRAS

\begin{tabular}{|c|c|c|c|c|c|c|c|c|c|}
\hline Batch \# & Run \# & Source & $\begin{array}{l}\text { Distance } \\
\text { (cm) }\end{array}$ & $\begin{array}{l}\text { Live } \\
\text { time } \\
\text { (sec) }\end{array}$ & $\begin{array}{c}\text { Net } \\
\text { Gamma } \\
\text { (cps) }\end{array}$ & $\begin{array}{l}\text { SNM } \\
\text { Prob. }\end{array}$ & Threat & $\begin{array}{c}\text { Chi } \\
\text { Square }\end{array}$ & Isotopes \\
\hline Batch053 & Run001 & HEU - Steel: $1.1 \mathrm{~mm}$ & 400 & 19.64 & 1787 & 3 (High) & $7(\mathrm{SNM}=\mathrm{H})$ & 0.70 & $\mathrm{U} 235$ (H, 10kg) \\
\hline Batch053 & Run002 & HEU - Steel: $1.1 \mathrm{~mm}$ & 400 & 19.64 & 1787 & 3 (High) & $7(\mathrm{SNM}=\mathrm{H})$ & 0.70 & $\mathrm{U} 235(\mathrm{H}, 10 \mathrm{~kg})$ \\
\hline Batch053 & Run003 & HEU - Steel: $1.1 \mathrm{~mm}$ & 400 & 19.48 & 1716 & 3 (High) & $7(\mathrm{SNM}=\mathrm{H})$ & 0.40 & U235 (H, 9kg), U237 (F, 27uCi) \\
\hline Batch053 & Run004 & HEU - Steel: $1.1 \mathrm{~mm}$ & 400 & 19.48 & 1716 & 3 (High) & 7 (SNM=H) & 0.41 & U235 (H, 9kg), U237 (F, 27uCi) \\
\hline Batch053 & Run005 & HEU - Steel: $1.1 \mathrm{~mm}$ & 400 & 19.30 & 1759 & 3 (High) & $7(\mathrm{SNM}=\mathrm{H})$ & 0.63 & $\mathrm{U} 235(\mathrm{H}, 9 \mathrm{~kg})$ \\
\hline Batch054 & Run001 & HEU - Steel: $1.1 \mathrm{~mm}$ & 400 & 19.26 & 1777 & 3 (High) & 7 (SNM=H) & 0.58 & $\mathrm{U} 235(\mathrm{H}, 10 \mathrm{~kg})$ \\
\hline Batch054 & Run002 & HEU - Steel: $1.1 \mathrm{~mm}$ & 400 & 19.26 & 1777 & 3 (High) & $7(\mathrm{SNM}=\mathrm{H})$ & 0.58 & U235 (H, 10kg) \\
\hline Batch054 & Run003 & HEU - Steel: $1.1 \mathrm{~mm}$ & 400 & 19.18 & 1767 & 3 (High) & 7 (SNM=H) & 0.59 & U235 (H, 12kg), U238 (F, 834g) \\
\hline Batch054 & Run004 & HEU - Steel: $1.1 \mathrm{~mm}$ & 400 & 19.58 & 1729 & 3 (High) & 7 (SNM=H) & 0.54 & U235 (H, 9kg) \\
\hline Batch054 & Run005 & HEU - Steel: $1.1 \mathrm{~mm}$ & 400 & 19.32 & 1738 & 3 (High) & $7(\mathrm{SNM}=\mathrm{H})$ & 0.53 & U235 (H, 9kg), U237 (F, 112uCi) \\
\hline Batch055 & Run001 & HEU - Steel: $7.5 \mathrm{~mm}$ & 100 & 19.40 & 963 & 3 (High) & $7(\mathrm{SNM}=\mathrm{H})$ & 0.49 & U235 (H, 493g) \\
\hline Batch055 & Run002 & HEU - Steel: $7.5 \mathrm{~mm}$ & 100 & 19.40 & 963 & 3 (High) & $7(\mathrm{SNM}=\mathrm{H})$ & 0.49 & $\mathrm{U} 235$ (H, 493g) \\
\hline Batch055 & Run003 & HEU - Steel: 7.5mm & 100 & 19.62 & 967 & 3 (High) & $7(\mathrm{SNM}=\mathrm{H})$ & 0.40 & U235 (H, 502g) \\
\hline Batch055 & Run004 & HEU - Steel: $7.5 \mathrm{~mm}$ & 100 & 19.62 & 967 & 3 (High) & 7 (SNM=H) & 0.40 & U235 (H, 502g) \\
\hline Batch055 & Run005 & HEU - Steel: $7.5 \mathrm{~mm}$ & 100 & 19.42 & 989 & 3 (High) & 7 (SNM=H) & 0.36 & $\mathrm{U} 235$ (H, 507g) \\
\hline Batch056 & Run001 & HEU - Steel: 7.5mm & 100 & 19.72 & 933 & 3 (High) & 7 (SNM=H) & 0.36 & U235 (H, 511g) \\
\hline Batch056 & Run002 & HEU - Steel: $7.5 \mathrm{~mm}$ & 100 & 19.42 & 927 & 3 (High) & $7(\mathrm{SNM}=\mathrm{H})$ & 0.48 & $\mathrm{U} 235$ (H, 510g) \\
\hline Batch056 & Run003 & HEU - Steel: $7.5 \mathrm{~mm}$ & 100 & 19.42 & 927 & 3 (High) & 7 (SNM=H) & 0.48 & $\mathrm{U} 235(\mathrm{H}, 510 \mathrm{~g})$ \\
\hline Batch056 & Run004 & HEU - Steel: $7.5 \mathrm{~mm}$ & 100 & 19.50 & 965 & 3 (High) & 7 (SNM=H) & 0.45 & U235 (H, 510g) \\
\hline Batch056 & Run005 & HEU - Steel: $7.5 \mathrm{~mm}$ & 100 & 19.22 & 925 & 3 (High) & 7 (SNM=H) & 0.38 & U235 (H, 497g) \\
\hline Batch057 & Run001 & HEU - Steel: $13.8 \mathrm{~mm}$ & 100 & 19.60 & 580 & 3 (High) & $7(\mathrm{SNM}=\mathrm{H})$ & 0.49 & U235 (H, 316g) \\
\hline Batch057 & Run002 & HEU - Steel: $13.8 \mathrm{~mm}$ & 100 & 19.58 & 613 & 3 (High) & 7 (SNM=H) & 0.54 & U235 (H, 317g) \\
\hline Batch057 & Run003 & HEU - Steel: $13.8 \mathrm{~mm}$ & 100 & 19.58 & 613 & 3 (High) & $7(\mathrm{SNM}=\mathrm{H})$ & 0.54 & U235 (H, 317g) \\
\hline Batch057 & Run004 & HEU - Steel: $13.8 \mathrm{~mm}$ & 100 & *No & ata saved i & file! & & & \\
\hline Batch057 & Run005 & HEU - Steel: $13.8 \mathrm{~mm}$ & 100 & 19.58 & 597 & 3 (High) & $7(\mathrm{SNM}=\mathrm{H})$ & 0.47 & U235 (H, 286g) \\
\hline Batch058 & Run001 & HEU - Steel: $13.8 \mathrm{~mm}$ & 100 & 19.26 & 654 & 3 (High) & 7 (SNM=H) & 0.49 & U235 (H, 330g) \\
\hline Batch058 & Run002 & HEU - Steel: $13.8 \mathrm{~mm}$ & 100 & 19.38 & 625 & 3 (High) & 7 (SNM=H) & 0.46 & U235 (H, 320g) \\
\hline Batch058 & Run003 & HEU - Steel: $13.8 \mathrm{~mm}$ & 100 & 19.38 & 625 & 3 (High) & $7(\mathrm{SNM}=\mathrm{H})$ & 0.46 & $\mathrm{U} 235(\mathrm{H}, 320 \mathrm{~g})$ \\
\hline Batch058 & Run004 & HEU - Steel: $13.8 \mathrm{~mm}$ & 100 & 19.64 & 621 & 3 (High) & 7 (SNM=H) & 0.40 & $\mathrm{U} 235$ (H, 326g) \\
\hline Batch058 & Run005 & HEU - Steel: $13.8 \mathrm{~mm}$ & 100 & 19.58 & 603 & 3 (High) & 7 (SNM=H) & 0.43 & $\mathrm{U} 235(\mathrm{H}, 321 \mathrm{~g})$ \\
\hline Batch060 & Run001 & WGPu - Steel: $6.35 \mathrm{~mm}$ & 100 & 17.50 & 18356 & 3 (High) & $7(\mathrm{SNM}=\mathrm{H})$ & 1.45 & Pu239(H, 2kg), U238(F, 50kg) \\
\hline Batch060 & Run002 & WGPu - Steel: $6.35 \mathrm{~mm}$ & 100 & 17.50 & 18356 & 3 (High) & 7 (SNM=H) & 1.45 & Pu239(H, 2kg), U238(F, 50kg) \\
\hline Batch060 & Run003 & WGPu - Steel: $6.35 \mathrm{~mm}$ & 100 & 17.58 & 18385 & 3 (High) & $7(\mathrm{SNM}=\mathrm{H})$ & 1.41 & Pu239(H, 2kg), U238(F, 55kg) \\
\hline Batch060 & Run004 & WGPu - Steel: $6.35 \mathrm{~mm}$ & 100 & 17.66 & 18253 & 3 (High) & $7(\mathrm{SNM}=\mathrm{H})$ & 2.00 & Pu239(H, 2kg), U238(F, 45kg) \\
\hline Batch060 & Run005 & WGPu - Steel: $6.35 \mathrm{~mm}$ & 100 & 17.84 & 18176 & 3 (High) & $7(\mathrm{SNM}=\mathrm{H})$ & 1.68 & Pu239(H, 2kg), U238(F, 40kg) \\
\hline Batch062 & Run001 & WGPu - Steel: $6.35 \mathrm{~mm}$ & 100 & 17.74 & 18368 & 3 (High) & 7 (SNM=H) & 0.81 & $\begin{array}{l}\text { Pu239(H, 768g), Am241(H, 753mCi), } \\
\text { Tl201(F, 44uCi), U238(F, 45kg) }\end{array}$ \\
\hline
\end{tabular}


Table D.2. (contd)

\begin{tabular}{|c|c|c|c|c|c|c|c|c|c|}
\hline Batch \# & Run \# & Source & $\begin{array}{l}\text { Distance } \\
(\mathrm{cm})\end{array}$ & $\begin{array}{l}\text { Live } \\
\text { time } \\
\text { (sec) }\end{array}$ & $\begin{array}{c}\text { Net } \\
\text { Gamma } \\
\text { (cps) }\end{array}$ & $\begin{array}{l}\text { SNM } \\
\text { Prob. }\end{array}$ & Threat & $\begin{array}{c}\text { Chi } \\
\text { Square }\end{array}$ & Isotopes \\
\hline Batch062 & Run002 & WGPu - Steel: $6.35 \mathrm{~mm}$ & 100 & 17.74 & 18368 & 3 (High) & $7(\mathrm{SNM}=\mathrm{H})$ & 0.81 & $\begin{array}{l}\text { Pu239(H, 768g), Am241(H, 753mCi), } \\
\text { Tl201(F, 44uCi), U238(F, 45kg) }\end{array}$ \\
\hline Batch062 & Run003 & WGPu - Steel: $6.35 \mathrm{~mm}$ & 100 & 17.70 & 18310 & 3 (High) & $7(\mathrm{SNM}=\mathrm{H})$ & 1.76 & Pu239(H, 1kg), U238(F, 43kg) \\
\hline Batch062 & Run004 & WGPu - Steel: $6.35 \mathrm{~mm}$ & 100 & 17.76 & 18148 & 3 (High) & $7(\mathrm{SNM}=\mathrm{H})$ & 1.77 & Pu239(H, 2kg), U238(F, 47kg) \\
\hline Batch062 & Run005 & WGPu - Steel: $6.35 \mathrm{~mm}$ & 100 & 17.64 & 18519 & 3 (High) & $7(\mathrm{SNM}=\mathrm{H})$ & 1.63 & Pu239(H, 2kg), U238(H, 59kg) \\
\hline Batch063 & Run001 & WGPu - Steel: 19.05mm & 100 & 18.30 & 10043 & 3 (High) & $7(\mathrm{SNM}=\mathrm{H})$ & 1.27 & Pu239(H, 704g) \\
\hline Batch063 & Run002 & WGPu - Steel: 19.05mm & 100 & 18.62 & 9952 & 3 (High) & $7(\mathrm{SNM}=\mathrm{H})$ & 0.82 & $\begin{array}{l}\text { P239(H, 665g), Cs137(F, 37mCi), } \\
\text { Ba133(F, 6uCi) }\end{array}$ \\
\hline Batch063 & Run003 & WGPu - Steel: 19.05mm & 100 & 18.62 & 9952 & 3 (High) & $7(\mathrm{SNM}=\mathrm{H})$ & 0.82 & $\begin{array}{l}\text { P239(H, 665g), Cs137(F, 37mCi), } \\
\text { Ba133(F, 6uCi) }\end{array}$ \\
\hline Batch063 & Run004 & WGPu - Steel: 19.05mm & 100 & 18.50 & 9919 & 3 (High) & $7(\mathrm{SNM}=\mathrm{H})$ & 0.98 & Pu239(H, 1kg) \\
\hline Batch063 & Run005 & WGPu - Steel: 19.05mm & 100 & 18.50 & 9919 & 3 (High) & $7(\mathrm{SNM}=\mathrm{H})$ & 0.98 & Pu239(H, 1kg) \\
\hline Batch064 & Run001 & WGPu - Steel: 19.05mm & 100 & 18.76 & 10013 & 3 (High) & $7(\mathrm{SNM}=\mathrm{H})$ & 1.50 & Pu239(H, 561g) \\
\hline Batch064 & Run002 & WGPu - Steel: 19.05mm & 100 & 18.76 & 10013 & 3 (High) & $7(\mathrm{SNM}=\mathrm{H})$ & 1.50 & Pu239(H, 561g) \\
\hline Batch064 & Run003 & WGPu - Steel: 19.05mm & 100 & 18.52 & 9824 & 3 (High) & $7(\mathrm{SNM}=\mathrm{H})$ & 0.77 & $\begin{array}{l}\text { Pu239(H, 674g), Cs137(F, 33mCi), } \\
\text { Ba133(F, 5uCi) }\end{array}$ \\
\hline Batch064 & Run004 & WGPu - Steel: 19.05mm & 100 & 18.46 & 9803 & 3 (High) & $7(\mathrm{SNM}=\mathrm{H})$ & 1.06 & Pu239(H, 856g) \\
\hline Batch064 & Run005 & WGPu - Steel: 19.05mm & 100 & 18.46 & 9803 & 3 (High) & $7(\mathrm{SNM}=\mathrm{H})$ & 1.06 & Pu239(H, 856g) \\
\hline Batch065 & Run001 & $\begin{array}{l}\text { WGPu - Steel: } 19.05 \mathrm{~mm} \text {, } \\
\text { Copper: } 6.35 \mathrm{~mm}\end{array}$ & 100 & 18.78 & 7412 & 3 (High) & $7(\mathrm{SNM}=\mathrm{H})$ & 0.77 & Pu239(H, 2kg), U235(F, 447g) \\
\hline Batch065 & Run002 & $\begin{array}{l}\text { WGPu - Steel: } 19.05 \mathrm{~mm} \text {, } \\
\text { Copper: } 6.35 \mathrm{~mm}\end{array}$ & 100 & 18.78 & 7412 & 3 (High) & $7(\mathrm{SNM}=\mathrm{H})$ & 0.77 & Pu239(H, 2kg), U235(F, 447g) \\
\hline Batch065 & Run003 & $\begin{array}{l}\text { WGPu - Steel: } 19.05 \mathrm{~mm} \text {, } \\
\text { Copper: } 6.35 \mathrm{~mm}\end{array}$ & 100 & 18.52 & 7236 & 3 (High) & $7(\mathrm{SNM}=\mathrm{H})$ & 1.09 & Pu239(H, 615g), U235(F, 425g) \\
\hline Batch065 & Run004 & $\begin{array}{l}\text { WGPu - Steel: } 19.05 \mathrm{~mm} \text {, } \\
\text { Copper: } 6.35 \mathrm{~mm}\end{array}$ & 100 & 18.52 & 7236 & 3 (High) & $7(\mathrm{SNM}=\mathrm{H})$ & 1.09 & Pu239(H, 615g), U235(F, 425g) \\
\hline Batch065 & Run005 & $\begin{array}{l}\text { WGPu - Steel: } 19.05 \mathrm{~mm} \text {, } \\
\text { Copper: } 6.35 \mathrm{~mm}\end{array}$ & 100 & 18.90 & 6827 & 3 (High) & $7(\mathrm{SNM}=\mathrm{H})$ & 0.64 & Pu239(H, 960g), U235(F, 401g) \\
\hline Batch066 & Run001 & $\begin{array}{l}\text { WGPu - Steel: } 19.05 \mathrm{~mm} \text {, } \\
\text { Copper: } 6.35 \mathrm{~mm}\end{array}$ & 100 & 18.60 & 7065 & 3 (High) & $7(\mathrm{SNM}=\mathrm{H})$ & 0.83 & Pu239(H, 966g), U235(F, 447g) \\
\hline Batch066 & Run002 & $\begin{array}{l}\text { WGPu - Steel: } 19.05 \mathrm{~mm} \text {, } \\
\text { Copper: } 6.35 \mathrm{~mm}\end{array}$ & 100 & 18.60 & 7065 & 3 (High) & $7(\mathrm{SNM}=\mathrm{H})$ & 0.83 & Pu239(H, 966g), U235(F, 447g) \\
\hline Batch066 & Run003 & $\begin{array}{l}\text { WGPu - Steel: } 19.05 \mathrm{~mm} \text {, } \\
\text { Copper: } 6.35 \mathrm{~mm}\end{array}$ & 100 & 18.98 & 6930 & 3 (High) & $7(\mathrm{SNM}=\mathrm{H})$ & 0.90 & Pu239(H, 1kg), U235(F, 380g) \\
\hline Batch066 & Run004 & $\begin{array}{l}\text { WGPu - Steel: } 19.05 \mathrm{~mm} \text {, } \\
\text { Copper: } 6.35 \mathrm{~mm}\end{array}$ & 100 & 18.98 & 6930 & 3 (High) & $7(\mathrm{SNM}=\mathrm{H})$ & 0.90 & Pu239(H, 1kg), U235(F, 380g) \\
\hline Batch066 & Run005 & $\begin{array}{l}\text { WGPu - Steel: } 19.05 \mathrm{~mm} \text {, } \\
\text { Copper: } 6.35 \mathrm{~mm}\end{array}$ & 100 & 18.90 & 6972 & 3 (High) & $7(\mathrm{SNM}=\mathrm{H})$ & 1.36 & Pu239(H, 795g) \\
\hline Batch067 & Run001 & $\begin{array}{l}\text { WGPu - Steel: } 19.05 \mathrm{~mm} \text {, } \\
\text { Copper: } 6.35 \mathrm{~mm} \text {, Lead: } \\
3.175 \mathrm{~mm}\end{array}$ & 100 & 19.16 & 5169 & 3 (High) & $7(\mathrm{SNM}=\mathrm{H})$ & 1.69 & $\begin{array}{l}\text { Pu239(H, 824g), Cs137(F, 126mCi), } \\
\text { Tl201(F, 1uCi) }\end{array}$ \\
\hline Batch067 & Run002 & $\begin{array}{l}\text { WGPu - Steel: } 19.05 \mathrm{~mm} \text {, } \\
\text { Copper: } 6.35 \mathrm{~mm} \text {, Lead: } \\
3.175 \mathrm{~mm}\end{array}$ & 100 & 19.06 & 5133 & 3 (High) & $7(\mathrm{SNM}=\mathrm{H})$ & 0.72 & $\begin{array}{l}\text { Pu239(H, 989g), U235(H, 462g), } \\
\text { U238(F, 1kg) }\end{array}$ \\
\hline Batch067 & Run003 & $\begin{array}{l}\text { WGPu - Steel: } 19.05 \mathrm{~mm} \text {, } \\
\text { Copper: } 6.35 \mathrm{~mm} \text {, Lead: } \\
3.175 \mathrm{~mm}\end{array}$ & 100 & 18.86 & 5049 & 3 (High) & $7(\mathrm{SNM}=\mathrm{H})$ & 0.72 & Pu239(H, 1kg), I123(H, 36uCi) \\
\hline
\end{tabular}


Table D.2. (contd)

\begin{tabular}{|c|c|c|c|c|c|c|c|c|c|}
\hline Batch \# & Run \# & Source & $\begin{array}{c}\text { Distance } \\
(\mathbf{c m})\end{array}$ & $\begin{array}{l}\text { Live } \\
\text { time } \\
\text { (sec) } \\
\end{array}$ & $\begin{array}{c}\text { Net } \\
\text { Gamma } \\
\text { (cps) }\end{array}$ & $\begin{array}{l}\text { SNM } \\
\text { Prob. }\end{array}$ & Threat & $\begin{array}{c}\text { Chi } \\
\text { Square }\end{array}$ & Isotopes \\
\hline Batch067 & Run004 & $\begin{array}{l}\text { WGPu - Steel: } 19.05 \mathrm{~mm} \text {, } \\
\text { Copper: } 6.35 \mathrm{~mm} \text {, Lead: } \\
3.175 \mathrm{~mm}\end{array}$ & 100 & 18.86 & 5049 & 3 (High) & 7 (SNM=H) & 0.72 & Pu239(H, 1kg), I123(H, 36uCi) \\
\hline Batch067 & Run005 & $\begin{array}{l}\text { WGPu - Steel: } 19.05 \mathrm{~mm} \text {, } \\
\text { Copper: } 6.35 \mathrm{~mm} \text {, Lead: } \\
3.175 \mathrm{~mm}\end{array}$ & 100 & 19.02 & 5418 & 3 (High) & $7(\mathrm{SNM}=\mathrm{H})$ & 2.16 & Pu239(H, 1kg), Tl201(H, 1uCi) \\
\hline Batch068 & Run001 & $\begin{array}{l}\text { WGPu - Steel: } 19.05 \mathrm{~mm} \text {, } \\
\text { Copper: } 6.35 \mathrm{~mm} \text {, Lead: } \\
3.175 \mathrm{~mm}\end{array}$ & 100 & 18.98 & 5008 & 3 (High) & $7(\mathrm{SNM}=\mathrm{H})$ & 0.77 & Pu239(H, 996g), U235(F, 426g) \\
\hline Batch068 & Run002 & $\begin{array}{l}\text { WGPu - Steel: } 19.05 \mathrm{~mm} \text {, } \\
\text { Copper: } 6.35 \mathrm{~mm} \text {, Lead: } \\
3.175 \mathrm{~mm}\end{array}$ & 100 & 18.98 & 5008 & 3 (High) & $7(\mathrm{SNM}=\mathrm{H})$ & 0.77 & Pu239(H, 996g), U235(F, 426g) \\
\hline Batch068 & Run003 & $\begin{array}{l}\text { WGPu - Steel: } 19.05 \mathrm{~mm} \text {, } \\
\text { Copper: } 6.35 \mathrm{~mm} \text {, Lead: } \\
3.175 \mathrm{~mm}\end{array}$ & 100 & 19.18 & 4868 & 3 (High) & $7(\mathrm{SNM}=\mathrm{H})$ & 1.66 & Pu239(H, 1kg), TI201(F, 1uCi) \\
\hline Batch068 & Run004 & $\begin{array}{l}\text { WGPu - Steel: } 19.05 \mathrm{~mm} \text {, } \\
\text { Copper: } 6.35 \mathrm{~mm} \text {, Lead: } \\
\text { 3.175mm }\end{array}$ & 100 & 19.18 & 4868 & 3 (High) & $7(\mathrm{SNM}=\mathrm{H})$ & 1.66 & Pu239(H, 1kg), TI201(F, 1uCi) \\
\hline Batch068 & Run005 & $\begin{array}{l}\text { WGPu - Steel: } 19.05 \mathrm{~mm} \text {, } \\
\text { Copper: } 6.35 \mathrm{~mm} \text {, Lead: } \\
\text { 3.175mm }\end{array}$ & 100 & 19.04 & 4898 & 3 (High) & $7(\mathrm{SNM}=\mathrm{H})$ & 0.78 & $\begin{array}{l}\text { Pu239(H, 976g), U235(F, 399g), } \\
\text { U238(F, 1kg) }\end{array}$ \\
\hline Batch069 & Run001 & WGPu - Lead: $50.8 \mathrm{~mm}$ & 100 & 19.54 & 3239 & 3 (High) & $7(\mathrm{SNM}=\mathrm{H})$ & 1.19 & $\begin{array}{l}\text { Np237(H, 21g), In111(H, 4uCi), } \\
\text { T1201(H, 601uCi), U237(H, 6uCi), } \\
\text { U235(F, 297g) }\end{array}$ \\
\hline Batch069 & Run002 & WGPu - Lead: $50.8 \mathrm{~mm}$ & 100 & 19.54 & 3239 & 3 (High) & $7(\mathrm{SNM}=\mathrm{H})$ & 1.19 & $\begin{array}{l}\text { Np237(H, 21g), In111(H, 4uCi), } \\
\text { T1201(H, 601uCi), U237(H, 6uCi), } \\
\text { U235(F, 297g) }\end{array}$ \\
\hline Batch069 & Run003 & WGPu - Lead: $50.8 \mathrm{~mm}$ & 100 & 19.44 & 3457 & 3 (High) & $7(\mathrm{SNM}=\mathrm{H})$ & 0.87 & $\begin{array}{l}\text { Np237(H, 23g), In111(H, 3uCi), } \\
\text { T1201(H, 691uCi), U235(H, 329g), } \\
\text { U237(F, 5uCi) }\end{array}$ \\
\hline Batch069 & Run004 & WGPu - Lead: $50.8 \mathrm{~mm}$ & 100 & 19.44 & 3457 & 3 (High) & $7(\mathrm{SNM}=\mathrm{H})$ & 0.87 & $\begin{array}{l}\text { Np237(H, 23g), In111(H, 3uCi), } \\
\text { T1201(H, 691uCi), U235(H, 329g), } \\
\text { U237(F, 5uCi) }\end{array}$ \\
\hline Batch069 & Run005 & WGPu - Lead: $50.8 \mathrm{~mm}$ & 100 & 19.20 & 3048 & 3 (High) & $7(\mathrm{SNM}=\mathrm{H})$ & 1.28 & $\begin{array}{l}\text { Np237(H, 20g), In111(H, 3uCi), } \\
\text { T1201(H, 547uCi), U235(H, 314g), } \\
\text { U237(F, 5uCi) }\end{array}$ \\
\hline Batch070 & Run001 & WGPu - Lead: $50.8 \mathrm{~mm}$ & 100 & 19.00 & 3142 & 3 (High) & 7 (SNM=H) & 1.37 & $\begin{array}{l}\text { In111(H, 3uCi), Np237(H, 21g), } \\
\text { U235(H, 375g), I123(H, 25uCi), } \\
\text { U237(F, 5uCi) }\end{array}$ \\
\hline Batch070 & Run002 & WGPu - Lead: $50.8 \mathrm{~mm}$ & 100 & 19.00 & 3142 & 3 (High) & $7(\mathrm{SNM}=\mathrm{H})$ & 1.37 & $\begin{array}{l}\text { In111(H, 3uCi), Np237(H, 21g), } \\
\text { U235(H, 375g), I123(H, 25uCi), } \\
\text { U237(F, 5uCi) }\end{array}$ \\
\hline Batch070 & Run003 & WGPu - Lead: $50.8 \mathrm{~mm}$ & 100 & 19.48 & 3075 & 3 (High) & $7(\mathrm{SNM}=\mathrm{H})$ & 1.17 & $\begin{array}{l}\text { Np237(H, 20g), In } 111(\mathrm{H}, 3 \mathrm{uCi}) \\
\text { TI201(H, 545uCi }), \text { U237( } \mathrm{H}, 6 \mathrm{uCi}) \\
\text { U235(H, 297g) }\end{array}$ \\
\hline Batch070 & Run004 & WGPu - Lead: $50.8 \mathrm{~mm}$ & 100 & 19.04 & 3105 & 3 (High) & $7(\mathrm{SNM}=\mathrm{H})$ & 1.09 & $\begin{array}{l}\text { Np237(H, 21g), In111(H, 3uCi), } \\
\text { TI201(H, 601uCi), U237(H, 6uCi), } \\
\text { U235(F, 273g) }\end{array}$ \\
\hline Batch070 & Run005 & WGPu - Lead: $50.8 \mathrm{~mm}$ & 100 & 19.76 & 3102 & 3 (High) & 7 (SNM=H) & 1.03 & $\begin{array}{l}\text { Np237( } \mathrm{H}, 22 \mathrm{~g}), \ln 111(\mathrm{H}, 3 \mathrm{uCi}), \\
\mathrm{T} 1201(\mathrm{H}, 546 \mathrm{uCi}), \mathrm{U} 235(\mathrm{H}, 309 \mathrm{~g}) \text {, } \\
\text { U237(F, 6uCi) }\end{array}$ \\
\hline Batch071 & Run001 & RGPu - Steel: $6.35 \mathrm{~mm}$ & 100 & 15.34 & 43178 & 3 (High) & $7(\mathrm{SNM}=\mathrm{H})$ & 2.05 & $\begin{array}{l}\text { Am241(H, 11Ci), Pu239(H, 6kg), } \\
\text { Th232 (H, 2uCi), U238(H, 11kg), } \\
\text { U237(H, 2Ci) }\end{array}$ \\
\hline Batch071 & Run002 & RGPu - Steel: $6.35 \mathrm{~mm}$ & 100 & 15.34 & 43178 & 3 (High) & $7(\mathrm{SNM}=\mathrm{H})$ & 2.05 & $\begin{array}{l}\text { Am241(H, 11Ci), Pu239(H, 6kg), } \\
\text { Th232 (H, 2uCi), U238(H, 11kg), }\end{array}$ \\
\hline
\end{tabular}


Table D.2. (contd)

\begin{tabular}{|c|c|c|c|c|c|c|c|c|c|}
\hline Batch \# & Run \# & Source & $\begin{array}{l}\text { Distance } \\
(\mathrm{cm})\end{array}$ & $\begin{array}{l}\text { Live } \\
\text { time } \\
\text { (sec) }\end{array}$ & $\begin{array}{c}\text { Net } \\
\text { Gamma } \\
\text { (cps) }\end{array}$ & $\begin{array}{l}\text { SNM } \\
\text { Prob. }\end{array}$ & Threat & $\begin{array}{c}\text { Chi } \\
\text { Square }\end{array}$ & Isotopes \\
\hline & & & & & & & & & $\mathrm{U} 237(\mathrm{H}, 2 \mathrm{Ci})$ \\
\hline Batch071 & Run003 & RGPu - Steel: $6.35 \mathrm{~mm}$ & 100 & 15.72 & 42875 & 3 (High) & $7(\mathrm{SNM}=\mathrm{H})$ & 1.93 & $\begin{array}{l}\text { Am241(H, 11Ci), Pu239(H, 5kg), } \\
\text { Th232 (H, 5uCi), U238(F, 456g), } \\
\text { U237(F, 546uCi), Mn54(F, 15uCi) }\end{array}$ \\
\hline Batch071 & Run004 & RGPu - Steel: $6.35 \mathrm{~mm}$ & 100 & 15.68 & 42892 & 3 (High) & $7(\mathrm{SNM}=\mathrm{H})$ & 1.40 & $\begin{array}{l}\text { Am241(H, 11Ci), Pu239(H, 4kg), } \\
\text { Th232(H, 6uCi), U237(H, 2Ci), } \\
\text { Bi207(F,1uCi), Mn54(F, 9uCi) }\end{array}$ \\
\hline Batch071 & Run005 & RGPu - Steel: $6.35 \mathrm{~mm}$ & 100 & 15.68 & 42798 & 3 (High) & $7(\mathrm{SNM}=\mathrm{H})$ & 2.40 & $\begin{array}{l}\text { Am241(H, 10Ci), Pu239(H, 4kg), } \\
\text { U238(H, 11kg), U237(F, 492uCi), } \\
\text { Ba133(F, 47uCi), U235(L, 356g) }\end{array}$ \\
\hline Batch072 & Run001 & RGPu - Steel: $6.35 \mathrm{~mm}$ & 100 & 15.94 & 42349 & 3 (High) & $7(\mathrm{SNM}=\mathrm{H})$ & 1.90 & $\begin{array}{l}\text { Am241(H, 10Ci), Pu239(H, 7kg), } \\
\text { Th232(H, 5uCi), U237(H, 99uCi), } \\
\text { U238(H, 2kg) }\end{array}$ \\
\hline Batch072 & Run002 & RGPu - Steel: $6.35 \mathrm{~mm}$ & 100 & 15.94 & 42349 & 3 (High) & $7(\mathrm{SNM}=\mathrm{H})$ & 1.90 & $\begin{array}{l}\text { Am241(H, 10Ci), Pu239(H, 7kg), } \\
\text { Th232(H, 5uCi), U237(H, 99uCi), } \\
\text { U238(H, 2kg) }\end{array}$ \\
\hline Batch072 & Run003 & RGPu - Steel: $6.35 \mathrm{~mm}$ & 100 & 16.02 & 42603 & 3 (High) & $7(\mathrm{SNM}=\mathrm{H})$ & 2.20 & $\begin{array}{l}\text { Am241(H, 11Ci), Pu239(H, 6kg), } \\
\text { Th232(H, 5uCi), U237(H, 2Ci }) \\
\text { U238(F, 52kg) }\end{array}$ \\
\hline Batch072 & Run004 & RGPu - Steel: $6.35 \mathrm{~mm}$ & 100 & 15.64 & 42996 & 3 (High) & $7(\mathrm{SNM}=\mathrm{H})$ & 2.40 & $\begin{array}{l}\text { Am241(H, 10Ci), Pu239(H, 7kg), } \\
\text { Th232(H, 5uCi), U238(H, 559g), } \\
\text { U237(F, 542uCi) }\end{array}$ \\
\hline Batch072 & Run005 & RGPu - Steel: $6.35 \mathrm{~mm}$ & 100 & 15.64 & 42996 & 3 (High) & $7(\mathrm{SNM}=\mathrm{H})$ & 2.40 & $\begin{array}{l}\text { Am241(H, 10Ci), Pu239(H, 7kg), } \\
\text { Th232(H, 5uCi), U238(H, 559g), } \\
\text { U237(F, 542uCi) }\end{array}$ \\
\hline Batch073 & Run001 & RGPu - Steel: $19.05 \mathrm{~mm}$ & 100 & 15.64 & 43114 & 3 (High) & $7(\mathrm{SNM}=\mathrm{H})$ & 2.80 & $\begin{array}{l}\text { Am241(H, 10Ci), Pu239(H, 6kg), } \\
\text { U237(H, 2Ci) }\end{array}$ \\
\hline Batch073 & Run002 & RGPu - Steel: $19.05 \mathrm{~mm}$ & 100 & 15.58 & 43062 & 3 (High) & $7(\mathrm{SNM}=\mathrm{H})$ & 2.30 & $\begin{array}{l}\text { Am241(H, 10Ci), Pu239(H, 7kg), } \\
\text { Th232(H, 5uCi), U237(H, 109uCi), } \\
\text { U238(F, 5kg) }\end{array}$ \\
\hline Batch073 & Run003 & RGPu - Steel: $19.05 \mathrm{~mm}$ & 100 & 15.58 & 43062 & 3 (High) & $7(\mathrm{SNM}=\mathrm{H})$ & 2.30 & $\begin{array}{l}\text { Am241(H, 10Ci), Pu239(H, 7kg), } \\
\text { Th232(H, 5uCi), U237(H, 109uCi), } \\
\text { U238(F, } 5 \mathrm{~kg})\end{array}$ \\
\hline Batch073 & Run004 & RGPu - Steel: $19.05 \mathrm{~mm}$ & 100 & 15.48 & 42820 & 3 (High) & $7(\mathrm{SNM}=\mathrm{H})$ & 2.10 & $\begin{array}{l}\text { Am241(H, 10Ci), Pu239(H, 4kg), } \\
\text { Th232(H, 5uCi), U238(F, 9kg), } \\
\text { U237(F, 493uCi), Ba133(F, 48uCi), } \\
\text { Mn54(F, 11uCi) }\end{array}$ \\
\hline Batch073 & Run005 & RGPu - Steel: $19.05 \mathrm{~mm}$ & 100 & 15.48 & 42820 & 3 (High) & $7(\mathrm{SNM}=\mathrm{H})$ & 2.10 & $\begin{array}{l}\text { Am241(H, 10Ci), Pu239(H, 4kg), } \\
\text { Th232(H, 5uCi), U238(F, 9kg), } \\
\text { U237(F, 493uCi), Ba133(F, 48uCi), } \\
\text { Mn54(F, 11uCi) }\end{array}$ \\
\hline Batch074 & Run001 & RGPu - Steel: $19.05 \mathrm{~mm}$ & 100 & 17.76 & 20167 & 3 (High) & $7(\mathrm{SNM}=\mathrm{H})$ & 1.70 & $\begin{array}{l}\text { Am241(H, 4Ci), Pu239(H, 1kg), } \\
\text { U235(F, 1 kg) }\end{array}$ \\
\hline Batch074 & Run002 & RGPu - Steel: $19.05 \mathrm{~mm}$ & 100 & 17.76 & 20167 & 3 (High) & $7(\mathrm{SNM}=\mathrm{H})$ & 1.70 & $\begin{array}{l}\text { Am241(H, 4Ci), Pu239(H, 1kg), } \\
\text { U235(F, 1 kg) }\end{array}$ \\
\hline Batch074 & Run003 & RGPu - Steel: $19.05 \mathrm{~mm}$ & 100 & 17.64 & 21126 & 3 (High) & $7(\mathrm{SNM}=\mathrm{H})$ & 1.60 & $\begin{array}{l}\text { Am241(H, 5Ci), Pu239(H, 1kg), } \\
\text { U235(F, 2kg) }\end{array}$ \\
\hline Batch074 & Run004 & RGPu - Steel: $19.05 \mathrm{~mm}$ & 100 & 17.64 & 21126 & 3 (High) & $7(\mathrm{SNM}=\mathrm{H})$ & 1.60 & $\begin{array}{l}\text { Am241(H, 5Ci), Pu239(H, 1 kg), } \\
\text { U235(F, 2kg) }\end{array}$ \\
\hline Batch074 & Run005 & RGPu - Steel: $19.05 \mathrm{~mm}$ & 100 & 17.54 & 20317 & 3 (High) & $7(\mathrm{SNM}=\mathrm{H})$ & 1.50 & $\operatorname{Am} 241(\mathrm{H}, 4 \mathrm{Ci}), \mathrm{Pu} 239(\mathrm{H}, 2 \mathrm{~kg})$ \\
\hline Batch075 & Run001 & RGPu - Steel: $19.05 \mathrm{~mm}$ & 100 & 17.56 & 20133 & 3 (High) & $7(\mathrm{SNM}=\mathrm{H})$ & 1.30 & $\begin{array}{l}\text { Am241(H, 4Ci), Pu239(H, 2kg), } \\
\text { U235(F, 1kg) }\end{array}$ \\
\hline Batch075 & Run002 & RGPu - Steel: $19.05 \mathrm{~mm}$ & 100 & 17.62 & 20430 & 3 (High) & $7(\mathrm{SNM}=\mathrm{H})$ & 1.60 & Am241(H, 4Ci), Pu239(H, 3kg) \\
\hline
\end{tabular}


Table D.2. (contd)

\begin{tabular}{|c|c|c|c|c|c|c|c|c|c|}
\hline Batch \# & Run \# & Source & $\begin{array}{c}\text { Distance } \\
(\mathrm{cm})\end{array}$ & $\begin{array}{c}\text { Live } \\
\text { time } \\
(\mathrm{sec}) \\
\end{array}$ & $\begin{array}{c}\text { Net } \\
\text { Gamma } \\
\text { (cps) }\end{array}$ & $\begin{array}{l}\text { SNM } \\
\text { Prob. }\end{array}$ & Threat & $\begin{array}{c}\text { Chi } \\
\text { Square }\end{array}$ & Isotopes \\
\hline Batch075 & Run003 & RGPu - Steel: $19.05 \mathrm{~mm}$ & 100 & 17.62 & 20430 & 3 (High) & $7(\mathrm{SNM}=\mathrm{H})$ & 1.60 & Am241(H, 4Ci), Pu239(H, 3kg) \\
\hline Batch075 & Run004 & RGPu - Steel: $19.05 \mathrm{~mm}$ & 100 & 17.44 & 20275 & 3 (High) & $7(\mathrm{SNM}=\mathrm{H})$ & 1.30 & $\begin{array}{l}\text { Am241(H, 4Ci), Pu239(H, 2kg), } \\
\text { I131(F, 219uCi) }\end{array}$ \\
\hline Batch075 & Run005 & RGPu - Steel: $19.05 \mathrm{~mm}$ & 100 & 17.44 & 20275 & 3 (High) & 7 (SNM=H) & 1.30 & $\begin{array}{l}\text { Am241(H, 4Ci), Pu239(H, 2kg), } \\
\text { I131(F, 219uCi) }\end{array}$ \\
\hline Batch077 & Run001 & $\begin{array}{l}\text { RGPu - Steel: } 19.05 \mathrm{~mm} \text {, } \\
\text { Copper: } 6.35 \mathrm{~mm}\end{array}$ & 100 & 18.02 & 16415 & 3 (High) & $7(\mathrm{SNM}=\mathrm{H})$ & 1.30 & $\begin{array}{l}\text { Pu239(H, 2kg), Am241(H, 951mCi), } \\
\text { Cs137(H, 289mCi), U235(F, 744g) }\end{array}$ \\
\hline Batch077 & Run002 & $\begin{array}{l}\text { RGPu - Steel: } 19.05 \mathrm{~mm} \text {, } \\
\text { Copper: } 6.35 \mathrm{~mm}\end{array}$ & 100 & 18.02 & 16415 & 3 (High) & 7 (SNM=H) & 1.30 & $\begin{array}{l}\text { Pu239(H, 2kg), Am241(H, 951mCi), } \\
\text { Cs137(H, 289mCi), U235(F, 744g) }\end{array}$ \\
\hline Batch077 & Run003 & $\begin{array}{l}\text { RGPu - Steel: } 19.05 \mathrm{~mm} \text {, } \\
\text { Copper: } 6.35 \mathrm{~mm}\end{array}$ & 100 & 17.72 & 16677 & 3 (High) & $7(\mathrm{SNM}=\mathrm{H})$ & 1.30 & $\begin{array}{l}\text { Am241(H, 2Ci), Cs137(H, 325mCi), } \\
\text { Pu239(H, 2kg) }\end{array}$ \\
\hline Batch077 & Run004 & $\begin{array}{l}\text { RGPu - Steel: } 19.05 \mathrm{~mm} \text {, } \\
\text { Copper: } 6.35 \mathrm{~mm}\end{array}$ & 100 & 17.72 & 16677 & 3 (High) & $7(\mathrm{SNM}=\mathrm{H})$ & 1.30 & $\begin{array}{l}\text { Am241(H, 2Ci), Cs137(H, 325mCi), } \\
\text { Pu239(H, 2kg) }\end{array}$ \\
\hline Batch077 & Run005 & $\begin{array}{l}\text { RGPu - Steel: } 19.05 \mathrm{~mm} \text {, } \\
\text { Copper: } 6.35 \mathrm{~mm}\end{array}$ & 100 & 17.76 & 16699 & 3 (High) & 7 (SNM=H) & 1.30 & $\begin{array}{l}\text { Am241(H, 3Ci), Pu239(H, 2kg), } \\
\text { U235(F, 2kg) }\end{array}$ \\
\hline
\end{tabular}




\section{Appendix E \\ Library of Isotopes Used for ScintiVision Analysis}





\section{Appendix E \\ Library of Isotopes Used for ScintiVision Analysis}

Table E.1. Library of Isotopes for ScintiVision Analysis

\begin{tabular}{|c|c|c|c|}
\hline $\begin{array}{l}\text { ISOTOPES } \\
\text { IDENTIFIED }\end{array}$ & HALF LIFE & UNCERTAINTY & ENERGY LINES (KEV) \\
\hline Am241 & $432.6 \mathrm{y}$ & $0.6 y$ & $26.35,59.54$ \\
\hline $\mathrm{Ba} 133$ & 10.52 y & $0.13 y$ & $80.89,276.40,302.85,356.02,383.85$ \\
\hline $\mathrm{Bi} 207$ & $32.9 \mathrm{y}$ & $0.14 \mathrm{y}$ & $569.70,1063.66,1770.23$ \\
\hline Co57 & $271.74 \mathrm{~d}$ & $0.06 \mathrm{~d}$ & $122.06,136.47,692.03$ \\
\hline Co60 & $5.273 \mathrm{y}$ & $0.005 \mathrm{y}$ & $1173.24,1332.50$ \\
\hline Cr51 & $27.7025 \mathrm{~d}$ & $0.00024 \mathrm{~d}$ & 320.082397 \\
\hline Cs137 & $30.08 \mathrm{y}$ & $0.09 \mathrm{y}$ & 661.66 \\
\hline Eu152 & $13.506 y$ & $0.006 \mathrm{y}$ & $121.78,244.65,344.30,778.90,964.00,1100.00,1408.00$ \\
\hline Ga67 & $3.2617 \mathrm{~d}$ & $0.0005 \mathrm{~d}$ & $93.16,184.58,208.95,300.22,393.53$ \\
\hline Ho166m & $1.200 \mathrm{e} 3 \mathrm{y}$ & $180 \mathrm{y}$ & $80.57,184.41,280.46,410.94,711.68,752.29,810.28$ \\
\hline 1123 & $13.2235 \mathrm{~h}$ & $0.0019 \mathrm{~h}$ & $158.97,528.96$ \\
\hline 1131 & $8.0252 \mathrm{~d}$ & $0.0006 \mathrm{~d}$ & $284.30,364.49,636.99,722.91$ \\
\hline $\ln 111$ & $2.8047 d$ & $0.0004 \mathrm{~d}$ & $171.28,245.40$ \\
\hline $\operatorname{lr} 192$ & $73.827 d$ & $0.0013 \mathrm{~d}$ & $310.64,469.10,602.82$ \\
\hline K40 & $1.248 \mathrm{e} 9 \mathrm{y}$ & $3000000 \mathrm{y}$ & 1460.83 \\
\hline Lu177m & $160.44 \mathrm{~d}$ & $0.06 \mathrm{~d}$ & $208.37,228.48,378.50,418.54$ \\
\hline Mn54 & $312.12 \mathrm{~d}$ & $0.06 \mathrm{~d}$ & 835 \\
\hline Mo99 & $65.94 \mathrm{~h}$ & $0.01 \mathrm{~h}$ & $40.58,140.51,181.06,366.42,739.50,777.92$ \\
\hline $\mathrm{Na} 22$ & $2.6027 \mathrm{y}$ & $0.001 \mathrm{y}$ & 1274.53 \\
\hline Np237 & $2.144 \mathrm{e} 6 \mathrm{y}$ & $7.00 E+03$ y & $29.37,86.48,96.30,310.44,340.81,375.45,398.62,415.76$ \\
\hline Pu239 & $24110 \mathrm{y}$ & $30 y$ & $38.66,51.62,129.30,203.55,376.03,413.71$ \\
\hline Pu241 & $14.290 \mathrm{y}$ & $0.006 \mathrm{y}$ & $151.70,208.00$ \\
\hline $\operatorname{Ra} 226$ & $1.600 \mathrm{e} 3 \mathrm{y}$ & $7 y$ & $186.21,295.22,609.32,768.36,1120.28,1238.11,1758.90,2204.12$ \\
\hline Se75 & $119.79 \mathrm{~d}$ & $0.04 \mathrm{~d}$ & $96.73,121.10,136.00,198.61,264.65,279.54,303.92,400.66$ \\
\hline Sm153 & $46.284 \mathrm{~h}$ & $0.004 \mathrm{~h}$ & $69.67,103.20$ \\
\hline Sr89 & $50.53 \mathrm{~d}$ & $0.07 \mathrm{~d}$ & 908.96 \\
\hline Th228 & $1.9116 \mathrm{y}$ & $0.0016 \mathrm{y}$ & $84.37,215.98$ \\
\hline Th232 & $1.4 \mathrm{e} 10 \mathrm{y}$ & $0.01 \mathrm{e} 10 \mathrm{y}$ & $\begin{array}{l}\text { 63.83, 140.86, 209.25, 238.84, 300.09, 338.32, 510.77, 583.19, 727.33, } \\
794.95,860.56,911.20,967.96,1588.19,2614.53\end{array}$ \\
\hline TI201 & $3.0421 \mathrm{~d}$ & $0.0017 \mathrm{~d}$ & $31.40,135.34,167.43$ \\
\hline U232 & $68.9 \mathrm{y}$ & $0.4 \mathrm{y}$ & $\begin{array}{l}\text { 209.25, 238.83, 300.87, 510.77, 583.19, 727. 33, 794.95, 860.56, 1588.19, } \\
2614.53\end{array}$ \\
\hline U233 & $1.592 \mathrm{e} 5 \mathrm{y}$ & $200 y$ & $29.19,42.44,54.70,146.35,164.52,291.35,317.16$ \\
\hline U235 & $7.04 \mathrm{e} 8 \mathrm{y}$ & $0.01 \mathrm{e} 8 \mathrm{y}$ & $25.65,143.76,163.36,185.71,205.31$ \\
\hline U237 & $6.75 \mathrm{~d}$ & $0.01 \mathrm{~d}$ & $59.54,208.00$ \\
\hline U238 & $4.468 \mathrm{e} 9 \mathrm{y}$ & $0.003 e 9 y$ & $49.55,63.29,92.58,112.81,113.50,766.38,1001.03$ \\
\hline
\end{tabular}





\section{Appendix $F$ Complete ScintiVision Results}





\section{Appendix $F$ \\ Complete ScintiVision Results}

Table F.1. Complete ScintiVision Results

\begin{tabular}{|c|c|c|c|c|c|}
\hline Batch & Source & $\begin{array}{l}\text { Nuclide (peak energy in keV) } \\
{ }^{*} D=\text { peak area deconvoluted }\end{array}$ & Uncertainty Sigma \% & Net Area Counts & Intensity (cnts/sec) \\
\hline Batch002 & WGPu 100g & $\begin{array}{l}\text { K40 }(1460.83) \\
\text { Th232 }(2614.53) \\
\text { Ra226 (186.21) D } \\
\text { Pu241 (208.00) D } \\
\text { T/201 (167.43) D } \\
\text { Th232 (338.32) D }\end{array}$ & $\begin{array}{c}8.09 \\
17.35 \\
23.12 \\
25.65 \\
32.07 \\
52.47\end{array}$ & $\begin{array}{r}607 \\
822 \\
713 \\
362 \\
517 \\
85\end{array}$ & $\begin{array}{r}32.240 \\
43.609 \\
37.854 \\
19.219 \\
27.455 \\
4.534\end{array}$ \\
\hline Batch003 & WGPu 100g & $\begin{array}{l}\text { K40 (1460.83) } \\
\text { U235 (205.31) D } \\
\text { I131 (636.99) D } \\
\text { Se75 (264.65) D } \\
\text { In111 (171.28) D } \\
\text { Co57 (692.03) D } \\
\text { Th232 (911.20) }\end{array}$ & $\begin{array}{c}10.13 \\
30.48 \\
31.79 \\
34.67 \\
41.60 \\
45.78 \\
119.69 \\
\end{array}$ & $\begin{array}{r}456 \\
595 \\
479 \\
208 \\
140 \\
41 \\
431 \\
\end{array}$ & \begin{tabular}{r|}
23.829 \\
31.117 \\
25.069 \\
10.885 \\
7.309 \\
2.145 \\
22.547 \\
\end{tabular} \\
\hline Batch004 & WGPu 100g & $\begin{array}{l}\text { Se75 (400.66) D } \\
\text { Mo99 (366.42) D } \\
\text { K40 (1460.83) } \\
\text { Th232 (338.32) D } \\
\text { Sm153 (103.20) }\end{array}$ & $\begin{array}{l}3.41 \\
4.73 \\
6.87 \\
8.70 \\
9.11 \\
\end{array}$ & $\begin{array}{r}2275 \\
2080 \\
4242 \\
5480 \\
604 \\
\end{array}$ & $\begin{array}{r}118.487 \\
108.341 \\
220.953 \\
285.435 \\
31.471 \\
\end{array}$ \\
\hline Batch005 & WGPu 100g & $\begin{array}{l}\text { K40 (1460.83) D } \\
\text { I123 (158.97) D } \\
\text { Co57 (122.06) D } \\
\text { Ra226 (1758.90) D }\end{array}$ & $\begin{array}{c}6.60 \\
12.67 \\
21.23 \\
24.20 \\
\end{array}$ & $\begin{array}{r}1065 \\
1418 \\
653 \\
131 \\
\end{array}$ & $\begin{array}{r}55.914 \\
74.462 \\
34.288 \\
6.877 \\
\end{array}$ \\
\hline Batch006 & WGPu 100g & K40 (1460.83) & 6.99 & 571 & 29.633 \\
\hline Batch007 & WGPu 100g & $\begin{array}{l}\text { K40 (1460.83) } \\
\text { Th232 (2614.53) } \\
\text { Pu241 (208.00) D } \\
\text { Ra226 (609.32) D } \\
\text { In111 }(245.40) D \\
\text { Co57 (692.03) D }\end{array}$ & $\begin{array}{c}6.99 \\
28.83 \\
42.07 \\
76.96 \\
98.89 \\
121.39 \\
\end{array}$ & $\begin{array}{r}331 \\
133 \\
78 \\
48 \\
560 \\
58 \\
\end{array}$ & $\begin{array}{r}17.205 \\
6.921 \\
4.055 \\
2.486 \\
29.144 \\
3.003 \\
\end{array}$ \\
\hline Batch008 & WGPu 100g & $\begin{array}{l}\text { Lu177m (378.50) D } \\
\text { K40 (1460.83) } \\
\text { Th232 (338.32) D } \\
\text { Ra226 (609.32) } \\
\end{array}$ & \begin{tabular}{|c|}
5.16 \\
8.60 \\
14.16 \\
51.93 \\
\end{tabular} & $\begin{array}{r}849 \\
2313 \\
107 \\
495 \\
\end{array}$ & $\begin{array}{r}43.572 \\
118.738 \\
5.467 \\
25.418 \\
\end{array}$ \\
\hline Batch009 & WGPu 100g & $\begin{array}{l}\text { K40 (1460.83) } \\
\text { Ra226 (1120.28) }\end{array}$ & $\begin{array}{r}6.70 \\
75.21 \\
\end{array}$ & $\begin{array}{r}59 \\
597 \\
\end{array}$ & $\begin{array}{r}3.040 \\
30.720 \\
\end{array}$ \\
\hline Batch011 & RGPu 98g & $\begin{array}{l}\text { Cs137 (661.66) } \\
\text { Th232 (338.32) } \\
\text { K40 (1460.83) } \\
\text { Th232 (2614.53) }\end{array}$ & $\begin{array}{c}6.39 \\
8.39 \\
8.40 \\
25.04 \\
\end{array}$ & $\begin{array}{r}2864 \\
1783 \\
534 \\
89 \\
\end{array}$ & $\begin{array}{r}158.581 \\
98.707 \\
29.577 \\
4.913 \\
\end{array}$ \\
\hline Batch012 & RGPu 98g & $\begin{array}{l}\text { Ba133 (383.85) D } \\
\text { Th232 (338.32) D } \\
\text { Cs137 (661.66) } \\
\text { K40 (1460.83) } \\
\text { Th232 (2614.53) } \\
\end{array}$ & $\begin{array}{c}3.81 \\
4.40 \\
5.63 \\
8.69 \\
15.92 \\
\end{array}$ & $\begin{array}{r}5726 \\
6500 \\
2027 \\
505 \\
135 \\
\end{array}$ & $\begin{array}{r}311.185 \\
353.264 \\
110.179 \\
27.449 \\
7.347 \\
\end{array}$ \\
\hline Batch013 & RGPu 98g & $\begin{array}{l}\text { K40 (1460.83) } \\
\text { Cs137 (661.66) } \\
\text { Th232 (2338.32) } \\
\text { Th232 (2614.53) } \\
\end{array}$ & $\begin{array}{c}8.18 \\
9.31 \\
10.62 \\
18.33 \\
\end{array}$ & $\begin{array}{r}1731 \\
967 \\
529 \\
102 \\
\end{array}$ & $\begin{array}{r}92.668 \\
51.783 \\
28.305 \\
5.458 \\
\end{array}$ \\
\hline Batch014 & RGPu 98g & $\begin{array}{l}\text { Ga67 (393.53) D } \\
\text { K40 (1460.83) } \\
\text { Eu152 (344.30) D } \\
\text { Th232 (2614.53) } \\
\text { I123 (158.97) }\end{array}$ & $\begin{array}{c}7.02 \\
9.25 \\
10.64 \\
20.33 \\
49.11\end{array}$ & $\begin{array}{r}460 \\
1845 \\
2655 \\
480 \\
98\end{array}$ & $\begin{array}{r}24.541 \\
98.460 \\
141.655 \\
25.616 \\
5.221\end{array}$ \\
\hline
\end{tabular}


Table F.1. (contd)

\begin{tabular}{|c|c|c|c|c|c|}
\hline Batch & Source & $\begin{array}{l}\text { Nuclide (peak energy in keV) } \\
{ }^{*} D=\text { peak area deconvoluted }\end{array}$ & Uncertainty Sigma \% & Net Area Counts & Intensity (cnts/sec) \\
\hline Batch015 & RGPu 98g & $\begin{array}{l}\text { K40 (1460.83) D } \\
\text { Cr51 (320.08) D } \\
\text { Ba133 (356.02) D } \\
\text { Ra226 (1758.90) D } \\
\text { Th232 (2614.53) }\end{array}$ & $\begin{array}{c}7.02 \\
13.06 \\
14.24 \\
34.73 \\
35.64 \\
\end{array}$ & $\begin{array}{r}1175 \\
1061 \\
654 \\
108 \\
54\end{array}$ & $\begin{array}{r}61.768 \\
55.795 \\
34.384 \\
5.667 \\
2.862\end{array}$ \\
\hline Batch016 & RGPu 98g & $\begin{array}{l}\text { K40 (1460.83) } \\
\text { Ga67 (393.53) D } \\
\text { Np237 (340.81) D }\end{array}$ & $\begin{array}{c}6.59 \\
8.61 \\
13.18 \\
\end{array}$ & $\begin{array}{r}1230 \\
1801 \\
609 \\
\end{array}$ & $\begin{array}{l}65.551 \\
96.027 \\
32.463 \\
\end{array}$ \\
\hline Batch017 & cs137 & $\begin{array}{l}\text { K40 (1460.83) } \\
\text { Cs137 (661.66) D } \\
\text { Co57 (692.03) D } \\
\text { U232 (238.83) }\end{array}$ & $\begin{array}{c}6.41 \\
8.44 \\
16.97 \\
153.56\end{array}$ & $\begin{array}{r}54 \\
849 \\
435 \\
640 \\
\end{array}$ & $\begin{array}{r}2.810 \\
43.948 \\
22.526 \\
33.151 \\
\end{array}$ \\
\hline Batch018 & cs137 & $\begin{array}{l}\text { Cs137 (661.66) } \\
\text { K40 (1460.83) } \\
\text { Ba133 (356.02) D } \\
\text { Th232 (2614.53) } \\
\text { U233 (291.35) D } \\
\text { Pu239 (203.55) D }\end{array}$ & $\begin{array}{c}6.06 \\
6.64 \\
47.83 \\
50.29 \\
73.22 \\
90.32 \\
\end{array}$ & $\begin{array}{r}96 \\
105 \\
152 \\
1096 \\
638 \\
37\end{array}$ & $\begin{array}{r}4.866 \\
5.335 \\
7.702 \\
55.560 \\
32.328 \\
1.865 \\
\end{array}$ \\
\hline Batch019 & cs137 & $\begin{array}{l}\text { K40 (1460.83) } \\
\text { Cs137 (661.66) D } \\
\text { Th232 (2614.53) } \\
\text { Eu152 (344.30) D } \\
\text { Th232 (238.84) D } \\
\text { U232 (510.77) D } \\
\text { Ba133 (276.40) D } \\
\end{array}$ & $\begin{array}{c}8.15 \\
12.95 \\
29.26 \\
39.13 \\
91.56 \\
108.79 \\
206.33 \\
\end{array}$ & $\begin{array}{r}86 \\
37 \\
174 \\
55 \\
472 \\
534 \\
53 \\
\end{array}$ & $\begin{array}{r}4.416 \\
1.886 \\
8.887 \\
2.821 \\
24.142 \\
27.317 \\
2.730\end{array}$ \\
\hline Batch020 & cs137 & $\begin{array}{l}\text { K40 (1460.83) } \\
\text { Cs137 (661.66) } \\
\text { Se75 (198.61) }\end{array}$ & $\begin{array}{l}10.23 \\
16.40 \\
99.54 \\
\end{array}$ & $\begin{array}{r}85 \\
381 \\
439 \\
\end{array}$ & $\begin{array}{r}4.299 \\
19.315 \\
22.302 \\
\end{array}$ \\
\hline Batch021 & Co60 & $\begin{array}{l}\text { Co60 (1173.24) D } \\
\text { Co60 (1332.50) D } \\
\text { K40 (1460.83) D } \\
\text { Th232 (2614.53) } \\
\text { Lu177m (228.48) }\end{array}$ & $\begin{array}{c}3.71 \\
4.60 \\
13.64 \\
42.42 \\
79.21 \\
\end{array}$ & $\begin{array}{r}126 \\
2594 \\
2276 \\
659 \\
42 \\
\end{array}$ & $\begin{array}{r}6.561 \\
134.566 \\
118.068 \\
34.184 \\
2.166 \\
\end{array}$ \\
\hline Batch022 & Co60 & $\begin{array}{l}\text { Co60 (1173.24) D } \\
\text { Co60 (1332.50) D } \\
\text { K40 (1460.83) D } \\
\text { Pu241 (208.00) D } \\
\text { Ba133 (356.02) D }\end{array}$ & \begin{tabular}{|c|}
3.64 \\
4.24 \\
13.54 \\
49.98 \\
78.14 \\
\end{tabular} & $\begin{array}{r}211 \\
116 \\
2613 \\
2430 \\
667\end{array}$ & $\begin{array}{r}10.867 \\
5.952 \\
134.400 \\
124.990 \\
34.315 \\
\end{array}$ \\
\hline Batch023 & Co60 & $\begin{array}{l}\text { Co60 (1173.24) D } \\
\text { K40 (1460.83) D } \\
\text { Co60 (1332.50) D } \\
\text { Th232 (2614.53) } \\
\text { Ra226 (1758.90) D } \\
\text { Ra226 (609.32) D } \\
\text { I123 (528.96) D }\end{array}$ & $\begin{array}{c}9.93 \\
10.67 \\
12.29 \\
14.79 \\
42.38 \\
74.30 \\
78.09 \\
\end{array}$ & $\begin{array}{r}86 \\
89 \\
692 \\
630 \\
651 \\
103 \\
91 \\
\end{array}$ & $\begin{array}{r}4.477 \\
4.628 \\
35.903 \\
32.700 \\
33.788 \\
5.336 \\
4.735 \\
\end{array}$ \\
\hline Batch024 & Co60 & $\begin{array}{l}\text { Co60 (1173.24) D } \\
\text { Co60 (1332.50) D } \\
\text { Th232 (2614.53) } \\
\text { U232 (238.83) D } \\
\text { Cr51 (253.99) D } \\
\text { U235 (205.31) D }\end{array}$ & $\begin{array}{l}12.27 \\
15.95 \\
24.49 \\
48.31 \\
77.60 \\
78.69 \\
\end{array}$ & $\begin{array}{r}111 \\
180 \\
97 \\
549 \\
433 \\
67 \\
\end{array}$ & $\begin{array}{r}5.727 \\
9.240 \\
4.998 \\
28.243 \\
22.253 \\
3.459 \\
\end{array}$ \\
\hline Batch025 & Co60 & $\begin{array}{l}\text { K40 (1460.83) D } \\
\text { Co60 (1173.24) D } \\
\text { Co60 (1332.50) D }\end{array}$ & $\begin{array}{c}8.27 \\
11.68 \\
19.02 \\
\end{array}$ & $\begin{array}{l}461 \\
326 \\
626 \\
\end{array}$ & $\begin{array}{l}24.203 \\
17.121 \\
32.889 \\
\end{array}$ \\
\hline Batch026 & Co60 & $\begin{array}{l}\text { Th232 (2614.53) } \\
\text { K40 (1460.83) } \\
\text { U232 (510.77) D } \\
\text { Ir192 (469.10) D } \\
\text { Ba133 (276.40) D } \\
\text { Eu152 (344.30) D }\end{array}$ & $\begin{array}{l}20.82 \\
31.23 \\
43.15 \\
49.37 \\
87.39 \\
88.67\end{array}$ & $\begin{array}{r}75 \\
92 \\
80 \\
129 \\
145 \\
183\end{array}$ & $\begin{array}{l}3.886 \\
4.760 \\
4.177 \\
6.697 \\
7.545 \\
9.501\end{array}$ \\
\hline
\end{tabular}


Table F.1. (contd)

\begin{tabular}{|c|c|c|c|c|c|}
\hline Batch & Source & $\begin{array}{l}\text { Nuclide (peak energy in keV) } \\
{ }^{*} D=\text { peak area deconvoluted }\end{array}$ & Uncertainty Sigma \% & Net Area Counts & Intensity (cnts/sec) \\
\hline & & U232 (238.83) D & 110.71 & 82 & 4.253 \\
\hline Batch027 & DU & $\begin{array}{l}\text { K40 (1460.83) } \\
\text { U232 (583.19) D } \\
\text { U232 (510.77) D } \\
\text { Ra226 (186.21) D } \\
\text { Se75 (279.54) D } \\
\text { In111 (245.40) D } \\
\text { In111 (171.28) D } \\
\text { Eu152 (344.30) D }\end{array}$ & $\begin{array}{c}8.57 \\
28.80 \\
42.82 \\
47.36 \\
71.06 \\
81.61 \\
95.19 \\
107.10 \\
\end{array}$ & $\begin{array}{r}125 \\
249 \\
141 \\
156 \\
95 \\
212 \\
310 \\
552 \\
\end{array}$ & $\begin{array}{r}6.455 \\
12.923 \\
7.283 \\
8.094 \\
4.923 \\
10.965 \\
16.066 \\
28.603 \\
\end{array}$ \\
\hline Batch028 & DU & $\begin{array}{l}\text { K40 (1460.83) } \\
\text { Th232 (2614.53) } \\
\text { Cr51 (320.08) D } \\
\text { Mo99 (366.42) D } \\
\text { Se75 (198.61) D }\end{array}$ & $\begin{array}{c}8.19 \\
16.47 \\
77.70 \\
110.20 \\
136.16 \\
\end{array}$ & $\begin{array}{r}87 \\
138 \\
93 \\
579 \\
86 \\
\end{array}$ & $\begin{array}{r}4.477 \\
7.118 \\
4.823 \\
29.885 \\
4.443 \\
\end{array}$ \\
\hline Batch029 & DU & U238 (1001.03) & 8.13 & 1101 & 57.345 \\
\hline Batch030 & DU & K40 (1460.83) & 8.55 & 586 & 30.859 \\
\hline Batch031 & $\operatorname{co5} 5$ & $\begin{array}{l}\text { Se75 (121.10) D } \\
\text { Ga67 (93.16) D } \\
\text { K40 (1460.83) D } \\
\text { Th232 (2614.53) } \\
\text { Co60 (1173.24) D }\end{array}$ & $\begin{array}{c}3.51 \\
6.86 \\
7.22 \\
19.39 \\
55.89 \\
\end{array}$ & $\begin{array}{r}1172 \\
3004 \\
78 \\
590 \\
73 \\
\end{array}$ & $\begin{array}{r}62.188 \\
159.459 \\
4.120 \\
31.313 \\
3.860 \\
\end{array}$ \\
\hline Batch032 & $\operatorname{co5} 5$ & $\begin{array}{l}\text { K40 (1460.83) } \\
\text { U238 (112.81) } \\
\text { Th232 (2614.53) } \\
\text { U232 (583.19) D } \\
\text { Eu152 (344.30) D } \\
\text { I123 (528.96) D } \\
\text { U232 (300.87) D } \\
\text { Unknown (443.33) D } \\
\text { In111 (245.40) }\end{array}$ & $\begin{array}{c}6.15 \\
10.10 \\
19.30 \\
28.12 \\
36.61 \\
45.71 \\
79.71 \\
80.31 \\
220.47 \\
\end{array}$ & $\begin{array}{r}985 \\
34 \\
85 \\
193 \\
85 \\
147 \\
222 \\
651 \\
80 \\
\end{array}$ & $\begin{array}{r}50.012 \\
1.730 \\
4.334 \\
9.781 \\
4.315 \\
7.455 \\
11.291 \\
33.047 \\
4.051 \\
\end{array}$ \\
\hline Batch033 & $\operatorname{co5} 5$ & K40 (1460.83) & 6.91 & 596 & 31.615 \\
\hline Batch034 & $\operatorname{co57}$ & $\begin{array}{l}\text { K40 (1460.83) } \\
\text { Th232 (2614.53) } \\
\text { Ba133 (356.02) D } \\
\text { Lu177m (228.48) D } \\
\text { Se75 (198.61) D }\end{array}$ & $\begin{array}{c}7.42 \\
29.51 \\
92.25 \\
103.40 \\
124.45 \\
\end{array}$ & $\begin{array}{r}66 \\
76 \\
69 \\
582 \\
54 \\
\end{array}$ & $\begin{array}{r}3.355 \\
3.892 \\
3.540 \\
29.672 \\
2.731 \\
\end{array}$ \\
\hline Batch035 & $\operatorname{co5} 7$ & $\operatorname{Co57}(122.06) \mathrm{D}$ & 3.07 & 1314 & 67.254 \\
\hline Batch035 & & $\begin{array}{l}\text { U238 (92.58) D } \\
\text { K40 (1460.83) } \\
\text { I123 (158.97) D } \\
\text { Th232 (2614.53) } \\
\text { Se75 (198.61) D } \\
\text { U232 (238.83) D }\end{array}$ & $\begin{array}{c}5.87 \\
6.90 \\
15.95 \\
15.99 \\
27.74 \\
67.61 \\
\end{array}$ & $\begin{array}{r}3061 \\
673 \\
295 \\
114 \\
619 \\
85 \\
\end{array}$ & $\begin{array}{r}156.670 \\
34.417 \\
15.115 \\
5.818 \\
31.654 \\
4.344 \\
\end{array}$ \\
\hline Batch036 & $\operatorname{co5} 5$ & $\begin{array}{l}\text { K40 (1460.83) } \\
\text { Np237 (86.48) } \\
\text { U232 (238.83) D } \\
\text { Th232 (338.32) D } \\
\text { Ra226 (609.32) } \\
\text { Ra226 (295.22) D } \\
\text { Unknown (436.79) D }\end{array}$ & $\begin{array}{c}7.52 \\
39.64 \\
57.30 \\
67.91 \\
68.08 \\
97.52 \\
133.68 \\
\end{array}$ & $\begin{array}{r}211 \\
135 \\
74 \\
99 \\
44 \\
82 \\
570 \\
\end{array}$ & $\begin{array}{r}10.521 \\
6.716 \\
3.699 \\
4.951 \\
2.180 \\
4.069 \\
28.407 \\
\end{array}$ \\
\hline Batch037 & Ba133 & $\begin{array}{l}\text { Eu152 (344.30) D } \\
\text { Pu239 (376.03) D } \\
\text { K40 (1460.83) } \\
\text { Ra226 (295.22) D } \\
\text { Th232 (2614.53) } \\
\text { U232 (583.19) } \\
\text { Se75 (121.10) }\end{array}$ & $\begin{array}{c}4.77 \\
6.02 \\
7.24 \\
10.07 \\
26.24 \\
60.45 \\
106.02 \\
\end{array}$ & $\begin{array}{r}96 \\
1038 \\
2639 \\
2018 \\
90 \\
573 \\
57 \\
\end{array}$ & $\begin{array}{r}4.959 \\
53.633 \\
136.316 \\
104.240 \\
4.633 \\
29.587 \\
2.960 \\
\end{array}$ \\
\hline Batch038 & Zirc Sand & $\begin{array}{l}\text { K40 (1460.83) D } \\
\text { Ra226 (609.32) D } \\
\text { Th232 (2614.53) D } \\
\text { Ra226 (1120.28) D }\end{array}$ & $\begin{array}{c}6.11 \\
8.74 \\
12.89 \\
22.85\end{array}$ & $\begin{array}{r}201 \\
337 \\
146 \\
1247\end{array}$ & $\begin{array}{r}6.820 \\
11.443 \\
4.968 \\
42.387\end{array}$ \\
\hline
\end{tabular}


Table F.1. (contd)

\begin{tabular}{|c|c|c|c|c|c|}
\hline Batch & Source & $\begin{array}{l}\text { Nuclide (peak energy in keV) } \\
{ }^{*} D=\text { peak area deconvoluted }\end{array}$ & Uncertainty Sigma \% & Net Area Counts & Intensity (cnts/sec) \\
\hline & & $\begin{array}{l}\text { Ra226 (2204.12) D } \\
\text { Ba133 (356.02) D } \\
\text { U232 (510.77) D } \\
\text { Lu177m (228.48) D }\end{array}$ & $\begin{array}{l}33.26 \\
42.36 \\
75.28 \\
80.27 \\
\end{array}$ & $\begin{array}{r}324 \\
1091 \\
97 \\
206 \\
\end{array}$ & $\begin{array}{r}11.005 \\
37.095 \\
3.310 \\
7.002\end{array}$ \\
\hline Batch039 & Zirc Sand & $\begin{array}{l}\text { Ra226 (609.32) D } \\
\text { Ra226 (1120.28) D } \\
\text { Ba133 (356.02) D } \\
\text { Ra226 (2204.12) } \\
\text { Eu152 (964.00) D } \\
\text { Mo99 (777.92) D } \\
\text { Th232 (238.83) D }\end{array}$ & $\begin{array}{c}4.25 \\
7.88 \\
9.26 \\
10.11 \\
13.93 \\
25.08 \\
29.79 \\
\end{array}$ & $\begin{array}{r}1005 \\
2899 \\
5278 \\
858 \\
1469 \\
2241 \\
628 \\
\end{array}$ & $\begin{array}{r}35.553 \\
102.595 \\
186.782 \\
30.377 \\
51.968 \\
79.312 \\
22.232 \\
\end{array}$ \\
\hline Batch040 & Ice Melt & K40 (1460.83) & 1.18 & 11872 & 406.287 \\
\hline Batch041 & Kitty Litter & $\begin{array}{l}\text { K40 (1460.83) } \\
\text { Ra226 (609.32) D } \\
\text { Eu152 (344.30) D } \\
\text { U232 (238.83) D } \\
\text { U232 (727.33) D } \\
\text { Se75 (264.65) D }\end{array}$ & $\begin{array}{c}5.52 \\
26.81 \\
46.31 \\
66.56 \\
73.14 \\
125.88 \\
\end{array}$ & $\begin{array}{r}161 \\
83 \\
193 \\
295 \\
103 \\
1031 \\
\end{array}$ & $\begin{array}{r}5.468 \\
2.798 \\
6.549 \\
9.985 \\
3.496 \\
34.946 \\
\end{array}$ \\
\hline Batch042 & Tiles & $\begin{array}{l}\text { K40 (1460.83) } \\
\text { Ra226 (609.32) }\end{array}$ & $\begin{array}{c}3.81 \\
35.22\end{array}$ & $\begin{array}{r}230 \\
1620 \\
\end{array}$ & $\begin{array}{r}7.810 \\
55.067\end{array}$ \\
\hline Batch043 & Fertilizer & K40 (1460.83) & 1.43 & 8728 & 300.359 \\
\hline Batch044 & Granite & $\begin{array}{l}\text { K40 (1460.83) D } \\
\text { Th232 (2614.53) } \\
\text { Ra226 (1120.28) D } \\
\text { Eu152 (244.65) D } \\
\text { Th232 (300.09) D } \\
\end{array}$ & $\begin{array}{c}4.00 \\
12.37 \\
30.94 \\
60.95 \\
177.57 \\
\end{array}$ & $\begin{array}{r}163 \\
52 \\
198 \\
1539 \\
146 \\
\end{array}$ & $\begin{array}{r}5.453 \\
1.729 \\
6.604 \\
51.332 \\
4.854 \\
\end{array}$ \\
\hline Batch045 & $\begin{array}{l}\text { Lanthanum } \\
\text { Carbonate }\end{array}$ & $\begin{array}{l}\text { K40 (1460.83) } \\
\text { Th232 (794.95) }\end{array}$ & $\begin{array}{l}2.90 \\
9.20\end{array}$ & $\begin{array}{r}883 \\
2249 \\
\end{array}$ & $\begin{array}{l}29.658 \\
75.556\end{array}$ \\
\hline Batch046 & HEU & $\begin{array}{l}\text { K40 (1460.83) } \\
\text { U232 (583.19) }\end{array}$ & $\begin{array}{c}5.69 \\
71.71 \\
\end{array}$ & $\begin{array}{r}77 \\
678 \\
\end{array}$ & $\begin{array}{r}3.953 \\
34.674 \\
\end{array}$ \\
\hline Batch047 & HEU & $\begin{array}{l}\text { K40 (1460.83) } \\
\text { Th232 (2614.53) }\end{array}$ & $\begin{array}{c}6.77 \\
16.69 \\
\end{array}$ & $\begin{array}{r}638 \\
86 \\
\end{array}$ & $\begin{array}{r}32.618 \\
4.396 \\
\end{array}$ \\
\hline Batch048 & HEU & $\begin{array}{l}\text { K40 (1460.83) } \\
\text { Sm153 (103.20) D } \\
\text { U235 (143.76) D } \\
\text { Th232 (2614.53) }\end{array}$ & $\begin{array}{c}8.16 \\
9.73 \\
16.78 \\
17.82\end{array}$ & $\begin{array}{r}1388 \\
732 \\
521 \\
79\end{array}$ & $\begin{array}{r}72.503 \\
38.236 \\
27.222 \\
4.145\end{array}$ \\
\hline Batch049 & HEU & K40 (1460.83) & 5.96 & 680 & 34.432 \\
\hline Batch050 & HEU & $\begin{array}{l}\text { K40 (1460.83) } \\
\text { Th232 (2614.53) } \\
\text { U235 (143.76) }\end{array}$ & $\begin{array}{c}6.90 \\
29.77 \\
234.75\end{array}$ & $\begin{array}{r}44 \\
580 \\
51\end{array}$ & $\begin{array}{r}2.256 \\
29.720 \\
2.615\end{array}$ \\
\hline Batch051 & HEU & $\begin{array}{l}\text { K40 (1460.83) } \\
\text { U233 (146.35) }\end{array}$ & $\begin{array}{c}7.27 \\
76.71 \\
\end{array}$ & $\begin{array}{l}136 \\
580 \\
\end{array}$ & $\begin{array}{r}7.050 \\
30.150 \\
\end{array}$ \\
\hline Batch052 & HEU & $\begin{array}{l}\text { K40 (1460.83) } \\
\text { U232 (583.19) D } \\
\text { I123 (528.96) D }\end{array}$ & $\begin{array}{c}7.18 \\
35.71 \\
139.58 \\
\end{array}$ & $\begin{array}{r}41 \\
152 \\
590 \\
\end{array}$ & $\begin{array}{r}2.123 \\
7.880 \\
30.525 \\
\end{array}$ \\
\hline Batch053 & HEU & $\begin{array}{l}\text { Sm153 (103.20) D } \\
\text { K40 (1460.83) } \\
\text { U233 (146.35) D } \\
\text { Th232 (2614.53) }\end{array}$ & $\begin{array}{c}7.15 \\
7.65 \\
14.05 \\
21.57 \\
\end{array}$ & $\begin{array}{r}2574 \\
1171 \\
533 \\
74 \\
\end{array}$ & $\begin{array}{r}131.064 \\
59.646 \\
27.117 \\
3.758 \\
\end{array}$ \\
\hline Batch054 & HEU & $\begin{array}{l}\text { Ga67 (184.58) } \\
\text { K40 (1460.83) }\end{array}$ & $\begin{array}{l}3.21 \\
8.14 \\
\end{array}$ & $\begin{array}{r}5175 \\
512 \\
\end{array}$ & $\begin{array}{r}268.673 \\
26.606 \\
\end{array}$ \\
\hline Batch055 & HEU & $\begin{array}{l}\text { K40 (1460.83) } \\
\text { Th232 (2614.53) } \\
\text { U232 (583.19) }\end{array}$ & $\begin{array}{c}7.05 \\
24.46 \\
76.64 \\
\end{array}$ & $\begin{array}{r}74 \\
581 \\
62 \\
\end{array}$ & $\begin{array}{r}3.798 \\
29.940 \\
3.178 \\
\end{array}$ \\
\hline Batch056 & HEU & $\begin{array}{l}\text { K40 (1460.83) } \\
\text { U233 (146.35) }\end{array}$ & $\begin{array}{c}6.40 \\
153.96 \\
\end{array}$ & $\begin{array}{r}92 \\
645 \\
\end{array}$ & $\begin{array}{r}7.738 \\
33.188 \\
\end{array}$ \\
\hline Batch057 & HEU & K40 (1460.83) & 5.65 & 696 & 35.552 \\
\hline Batch058 & HEU & $\begin{array}{l}\text { K40 (1460.83) } \\
\text { In111 (171.28) }\end{array}$ & $\begin{array}{l}8.32 \\
9.21\end{array}$ & $\begin{array}{r}1304 \\
491\end{array}$ & $\begin{array}{l}67.291 \\
25.319\end{array}$ \\
\hline
\end{tabular}


Table F.1. (contd)

\begin{tabular}{|c|c|c|c|c|c|}
\hline Batch & Source & $\begin{array}{l}\text { Nuclide (peak energy in keV) } \\
{ }^{*} D=\text { peak area deconvoluted }\end{array}$ & Uncertainty Sigma \% & Net Area Counts & Intensity (cnts/sec) \\
\hline & & Th232 (2614.53) & 17.92 & 69 & 3.580 \\
\hline Batch059 & HEU & & & & \\
\hline Batch060 & HEU & $\begin{array}{l}\text { K40 (1460.83) } \\
\text { Cs137 (661.66) } \\
\text { Pu241 (208.00) D } \\
\text { In111 (245.40) D }\end{array}$ & $\begin{array}{c}8.49 \\
15.83 \\
16.96 \\
33.30\end{array}$ & $\begin{array}{r}2089 \\
1029 \\
669 \\
500\end{array}$ & $\begin{array}{r}119.381 \\
58.801 \\
38.224 \\
28.554\end{array}$ \\
\hline Batch061 & WGPu & & & & \\
\hline Batch062 & WGPu & $\begin{array}{l}\text { U238 (113.50) D } \\
\text { U238 (92.58) D } \\
\text { U233 (146.35) D } \\
\text { Ra226 (186.21) D } \\
\text { K40 (1460.83) }\end{array}$ & $\begin{array}{l}1.45 \\
2.18 \\
2.61 \\
3.67 \\
7.65 \\
\end{array}$ & $\begin{array}{r}12149 \\
21484 \\
14925 \\
9867 \\
579\end{array}$ & $\begin{array}{r}684.815 \\
1211.024 \\
841.336 \\
556.210 \\
32.638 \\
\end{array}$ \\
\hline Batch063 & WGPu & $\begin{array}{l}\text { K40 (1460.83) } \\
\text { U235 (163.36) }\end{array}$ & $\begin{array}{c}7.45 \\
90.14\end{array}$ & $\begin{array}{l}329 \\
584\end{array}$ & $\begin{array}{l}17.656 \\
31.358\end{array}$ \\
\hline Batch064 & WGPu & $\begin{array}{l}\text { K40 (1460.83) } \\
\text { I123 (158.97) }\end{array}$ & $\begin{array}{c}7.38 \\
17.97\end{array}$ & $\begin{array}{r}1626 \\
558\end{array}$ & $\begin{array}{l}86.687 \\
29.730\end{array}$ \\
\hline Batch065 & WGPu & $\begin{array}{l}\text { U233 (164.52) D } \\
\text { K40 (1460.83) } \\
\text { Pu239 (129.30) D } \\
\text { Se75 (303.92) D } \\
\text { Ra226 (609.32) } \\
\text { Lu177m (228.48) D }\end{array}$ & \begin{tabular}{c|}
6.80 \\
7.70 \\
14.65 \\
27.63 \\
51.30 \\
83.37 \\
\end{tabular} & $\begin{array}{r}1878 \\
4137 \\
292 \\
808 \\
138 \\
536 \\
\end{array}$ & $\begin{array}{r}99.975 \\
220.284 \\
15.572 \\
43.044 \\
7.333 \\
28.552 \\
\end{array}$ \\
\hline Batch066 & WGPu & $\begin{array}{l}\text { K40 (1460.83) D } \\
\text { U235 (163.36) D } \\
\text { Co57 (136.47) D } \\
\text { Th232 (2614.53) } \\
\text { Ra226 (186.21) D } \\
\text { Se75 (264.65) D } \\
\text { Co60 (1173.24) D }\end{array}$ & \begin{tabular}{|c|}
7.83 \\
8.68 \\
17.49 \\
19.70 \\
43.38 \\
52.23 \\
120.47 \\
\end{tabular} & $\begin{array}{r}1530 \\
3070 \\
604 \\
437 \\
39 \\
588 \\
81\end{array}$ & $\begin{array}{r}82.261 \\
165.040 \\
32.469 \\
23.478 \\
2.088 \\
31.615 \\
4.340\end{array}$ \\
\hline Batch067 & WGPu & $\begin{array}{l}\text { U235 (163.36) D } \\
\text { Lu177m (228.48) D }\end{array}$ & $\begin{array}{l}17.73 \\
37.88\end{array}$ & $\begin{array}{r}1330 \\
518\end{array}$ & $\begin{array}{l}69.767 \\
27.162\end{array}$ \\
\hline Batch068 & WGPu & $\begin{array}{l}\text { K40 (1460.83) } \\
\text { Ho166m }(410.94) \text { D } \\
\text { Mo99 (366.42) D }\end{array}$ & $\begin{array}{c}8.18 \\
12.99 \\
17.94 \\
\end{array}$ & $\begin{array}{r}982 \\
1243 \\
537 \\
\end{array}$ & $\begin{array}{l}51.731 \\
65.485 \\
28.268 \\
\end{array}$ \\
\hline Batch069 & WGPu & $\begin{array}{l}\text { K40 (1460.83) } \\
\text { Ra226 (609.32) D } \\
\text { U232 (510.77) D }\end{array}$ & $\begin{array}{c}7.94 \\
23.78 \\
48.89\end{array}$ & $\begin{array}{l}120 \\
246 \\
548\end{array}$ & $\begin{array}{r}6.117 \\
12.593 \\
28.034\end{array}$ \\
\hline Batch070 & WGPu & $\begin{array}{l}\text { K40 (1460.83) } \\
\text { Th232 (2614.53) } \\
\text { U235 (163.36) }\end{array}$ & $\begin{array}{c}6.54 \\
25.95 \\
100.55\end{array}$ & $\begin{array}{r}213 \\
619 \\
58\end{array}$ & $\begin{array}{r}11.203 \\
32.590 \\
3.057\end{array}$ \\
\hline Batch071 & RGPu & $\begin{array}{l}\text { Cs137 (661.66) D } \\
\text { U232 (727.33) D } \\
\text { K40 (1460.83) } \\
\text { I123 (158.97) }\end{array}$ & $\begin{array}{c}2.81 \\
3.89 \\
15.41 \\
42.99 \\
\end{array}$ & $\begin{array}{r}1152 \\
9037 \\
6299 \\
373 \\
\end{array}$ & $\begin{array}{r}75.065 \\
589.122 \\
410.621 \\
24.336 \\
\end{array}$ \\
\hline Batch072 & RGPu & $\begin{array}{l}\text { Cs137 (661.66) } \\
\text { Cr51 (320.08) } \\
\text { Th232 (2614.53) } \\
\text { I123 (158.97) }\end{array}$ & $\begin{array}{c}2.97 \\
3.75 \\
10.16 \\
38.04\end{array}$ & $\begin{array}{r}1317 \\
12690 \\
8154 \\
431 \\
\end{array}$ & $\begin{array}{r}82.597 \\
796.096 \\
511.533 \\
27.058 \\
\end{array}$ \\
\hline Batch073 & RGPu & $\begin{array}{l}\text { Mo99 (366.42) D } \\
\text { Cr51 (320.08) D } \\
\text { Cs137 (661.66) D } \\
\text { Co57 (692.03) D } \\
\text { U232 (727.33) D } \\
\text { Th232 (2614.53) } \\
\end{array}$ & \begin{tabular}{c|}
2.38 \\
2.97 \\
4.27 \\
4.80 \\
5.82 \\
11.10 \\
\end{tabular} & $\begin{array}{r}16891 \\
21164 \\
6100 \\
5491 \\
4321 \\
380 \\
\end{array}$ & $\begin{array}{r}1084.162 \\
1358.418 \\
391.525 \\
352.416 \\
277.311 \\
24.372 \\
\end{array}$ \\
\hline Batch074 & RGPu & $\begin{array}{l}\text { Mo99 (366.42) D } \\
\text { Cs137 (661.66) } \\
\text { Cr51 (320.08) D } \\
\text { K40 (1460.83) } \\
\text { Th232 (2614.53) } \\
\text { I123 (158.97) }\end{array}$ & \begin{tabular}{c|}
5.02 \\
5.27 \\
5.48 \\
10.35 \\
13.15 \\
58.48 \\
\end{tabular} & $\begin{array}{r}667 \\
6261 \\
6698 \\
3269 \\
523 \\
287\end{array}$ & $\begin{array}{r}37.559 \\
352.515 \\
377.151 \\
184.056 \\
29.472 \\
16.181\end{array}$ \\
\hline Batch075 & RGPu & Cs137 (661.66) D & 4.55 & 3177 & 180.293 \\
\hline
\end{tabular}


Table F.1. (contd)

\begin{tabular}{|c|c|c|c|c|c|}
\hline Batch & Source & $\begin{array}{l}\text { Nuclide (peak energy in keV) } \\
{ }^{*} D=\text { peak area deconvoluted }\end{array}$ & Uncertainty Sigma \% & Net Area Counts & Intensity (cnts/sec) \\
\hline & & $\begin{array}{l}\text { Pu239 (203.55) D } \\
\text { I131 (722.91) D } \\
\text { In111 (171.28) D } \\
\text { Th232 (2614.53) } \\
\text { Th232 (338.32) D } \\
\text { K40 (1460.83) } \\
\text { U233 (146.35) D } \\
\text { Lu177m (228.48) D }\end{array}$ & $\begin{array}{c}4.83 \\
6.39 \\
7.58 \\
10.08 \\
11.80 \\
12.38 \\
12.46 \\
33.73 \\
\end{array}$ & $\begin{array}{r}5233 \\
8031 \\
1120 \\
2912 \\
3987 \\
2720 \\
449 \\
352 \\
\end{array}$ & $\begin{array}{r}296.974 \\
455.809 \\
63.559 \\
165.283 \\
226.292 \\
154.352 \\
25.482 \\
19.953\end{array}$ \\
\hline Batch076 & $?$ & & & & \\
\hline Batch077 & RGPu & $\begin{array}{l}\text { K40 (1460.83) D } \\
\text { Th232 (2614.53) } \\
\text { I123 (158.97) } \\
\text { Bi207 (1770.23) D }\end{array}$ & $\begin{array}{c}9.49 \\
14.35 \\
34.59 \\
35.74\end{array}$ & $\begin{array}{r}1051 \\
602 \\
135 \\
232\end{array}$ & $\begin{array}{r}58.342 \\
33.410 \\
7.507 \\
12.867\end{array}$ \\
\hline Batch078 & Yellowcake & $\begin{array}{l}\text { Ba133 (383.85) D } \\
\text { Np237 (340.81) D } \\
\text { Cs137 (661.66) } \\
\text { Th232 (2614.53) } \\
\text { Np237 (310.44) D }\end{array}$ & $\begin{array}{c}5.76 \\
6.54 \\
6.89 \\
10.59 \\
14.54 \\
\end{array}$ & $\begin{array}{r}2086 \\
4622 \\
4932 \\
2157 \\
289 \\
\end{array}$ & $\begin{array}{r}116.782 \\
258.806 \\
276.146 \\
120.774 \\
16.157 \\
\end{array}$ \\
\hline Batch079 & Yellowcake & $\begin{array}{l}\text { K40 (1460.83) D } \\
\text { Se75 (96.73) D } \\
\text { U238 (1001.03) } \\
\text { Ra226 (186.21) D } \\
\text { Ra226 (1758.90) D }\end{array}$ & $\begin{array}{c}7.37 \\
9.65 \\
11.08 \\
13.60 \\
26.36 \\
\end{array}$ & $\begin{array}{r}1440 \\
891 \\
597 \\
653 \\
143\end{array}$ & $\begin{array}{r}73.451 \\
45.477 \\
30.435 \\
33.335 \\
7.306\end{array}$ \\
\hline Batch080 & Yellowcake & $\begin{array}{l}\text { K40 (1460.83) } \\
\text { U238 (1001.03) } \\
\text { Th232 (2614.53) } \\
\text { Sm153 (103.20) } \\
\end{array}$ & $\begin{array}{c}8.41 \\
9.47 \\
27.00 \\
39.52 \\
\end{array}$ & $\begin{array}{r}374 \\
692 \\
531 \\
61 \\
\end{array}$ & $\begin{array}{r}19.173 \\
35.445 \\
27.223 \\
3.146 \\
\end{array}$ \\
\hline Batch081 & Yellowcake & $\begin{array}{l}\text { K40 (1460.83) } \\
\text { U238 (1001.03) }\end{array}$ & $\begin{array}{c}8.23 \\
11.23 \\
\end{array}$ & $\begin{array}{l}590 \\
549 \\
\end{array}$ & $\begin{array}{l}30.412 \\
28.323 \\
\end{array}$ \\
\hline Batch082 & Heisenberg & $\begin{array}{l}\text { Th232 (2614.53) } \\
\text { U232 (510.77) D } \\
\text { In111 (171.28) D } \\
\text { Se75 (264.65) D }\end{array}$ & $\begin{array}{c}35.26 \\
60.82 \\
69.80 \\
138.48 \\
\end{array}$ & $\begin{array}{r}159 \\
77 \\
130 \\
43 \\
\end{array}$ & $\begin{array}{l}8.139 \\
3.970 \\
6.660 \\
2.210 \\
\end{array}$ \\
\hline Batch083 & Heisenberg & $\begin{array}{l}\text { K40 (1460.83) } \\
\text { Th232 (2614.53) } \\
\text { U238 (1001.03) } \\
\text { Ho166m (184.41) }\end{array}$ & $\begin{array}{c}7.54 \\
19.19 \\
21.09 \\
174.00 \\
\end{array}$ & $\begin{array}{r}61 \\
298 \\
594 \\
83 \\
\end{array}$ & $\begin{array}{r}3.066 \\
14.902 \\
29.698 \\
4.151 \\
\end{array}$ \\
\hline Batch084 & Heisenberg & $\begin{array}{l}\text { U238 (1001.03) } \\
\text { K40 (1460.83) }\end{array}$ & $\begin{array}{l}7.15 \\
7.17 \\
\end{array}$ & $\begin{array}{r}1079 \\
663 \\
\end{array}$ & $\begin{array}{l}55.271 \\
33.979\end{array}$ \\
\hline Batch085 & Heisenberg & $\begin{array}{l}\text { K40 (1460.83) } \\
\text { Se75 (96.73) D } \\
\text { U235 (205.31) D } \\
\text { Mo99 (181.06) D }\end{array}$ & $\begin{array}{c}8.21 \\
12.13 \\
22.96 \\
27.24 \\
\end{array}$ & $\begin{array}{r}1185 \\
494 \\
577 \\
575 \\
\end{array}$ & $\begin{array}{l}60.528 \\
25.233 \\
29.483 \\
29.351\end{array}$ \\
\hline Batch086 & Heisenberg & & & & \\
\hline Batch087 & Heisenberg & $\begin{array}{l}\text { K40 (1460.83) } \\
\text { U238 (1001.03) D } \\
\text { U238 (766.38) D } \\
\text { Th232 (2614.53) } \\
\text { Pu239 (203.55) D } \\
\text { Mo99 (181.06) D } \\
\text { Ba133 (356.02) D } \\
\text { Ho166m (410.94) D } \\
\text { U233 (317.16) D }\end{array}$ & $\begin{array}{c}4.11 \\
5.09 \\
11.49 \\
12.58 \\
22.62 \\
27.77 \\
64.51 \\
72.64 \\
96.26 \\
\end{array}$ & $\begin{array}{r}841 \\
1035 \\
219 \\
311 \\
260 \\
1369 \\
2744 \\
1927 \\
197 \\
\end{array}$ & $\begin{array}{r}14.422 \\
17.758 \\
3.750 \\
5.341 \\
4.464 \\
23.485 \\
47.079 \\
33.058 \\
3.385 \\
\end{array}$ \\
\hline Batch088 & Yellowcake & $\begin{array}{l}\text { K40 (1460.83) } \\
\text { U238 (1001.03) } \\
\text { Se75 (198.61) D } \\
\text { Mo99 (181.06) D } \\
\text { Ba133 (356.02) D } \\
\text { U233 (317.16) D }\end{array}$ & $\begin{array}{c}4.14 \\
7.10 \\
18.38 \\
21.80 \\
67.78 \\
171.84 \\
\end{array}$ & $\begin{array}{r}989 \\
1169 \\
108 \\
258 \\
1585 \\
1801 \\
\end{array}$ & $\begin{array}{r}17.154 \\
20.265 \\
1.865 \\
4.472 \\
27.483 \\
31.229 \\
\end{array}$ \\
\hline Batch089 & Yellowcake & K40 (1460.83) & 4.27 & 1760 & 30.235 \\
\hline Batch090 & Unlabeled & K40 (1460.83) D & 3.63 & 732 & 12.600 \\
\hline
\end{tabular}


Table F.1. (contd)

\begin{tabular}{|c|l|l|c|r|r|}
\hline \multirow{3}{*}{ Batch } & Source & Nuclide (peak energy in keV) & & Net Area Counts & Intensity (cnts/sec) \\
\hline & & Th232 $(2614.53)$ & 11.23 & 1061 & 18.250 \\
& & Ra226 (1758.90) D & 14.14 & 2155 & 37.074 \\
& & Se75 (198.61) D & 18.89 & 411 & 7.077 \\
& & Tl201 (167.43) D & 27.56 & 219 & 3.771 \\
\hline
\end{tabular}




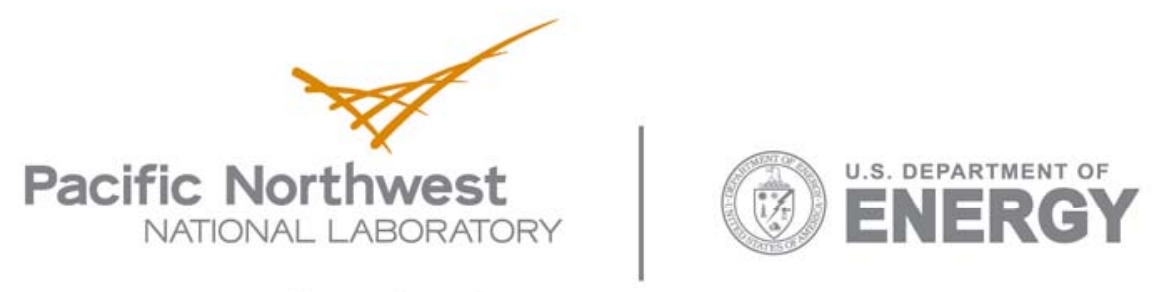

902 Battelle Boulevard

P.O. Box 999

Richland, WA 99352

1-888-375-PNNL (7665)

www.pnl.gov 